\title{
HANFORD A AND AX-FARM LEAK ASSESSMENTS REPORT: 241-A-103, 241-A-104, 241-A-105, 241 AX-102, 241-AX-104 AND UNPLANNED WASTE RELEASES
}

\author{
M. E. Johnson \\ CH2M HILL Hanford Group lnc. \\ Richland, WA 99352 \\ U.S. Department of Energy Contract DE-AC27-99RL14047

$\begin{array}{lll}\text { EDT/ECN: } & \text { DRF } & \text { UC: N/A } \\ \text { Cost Center: } & 77 \mathrm{C} 00 & \text { Charge Code: } 110172 \\ \text { B\&R Code: } & \text { N/A } & \text { Total Pages: } \mathbb{1 1 0}\end{array}$

Key Words: Tank waste loss events, vadose zone, 241-A-103, 241-A-104, 241-A-105, 241-AX-102, 241$\mathrm{AX}-104$

Abstract: This report summarizes information on historical waste loss events associated with tanks and pipelines in the 241-A and 24I-AX tank farms.

TRADEMARK DISCLAIMER. Reference herein to any specific commercial product, process, or service by trade name trademark, manufacturer, or otherwise, does not necessarily constitute or imply its endorsement, recommendation, or favoring by the United States Government or any agency thereof or its contractors or subcontractors.

Printed in the United States of America. To obtain copies of this document, contact: Document Control Services P. B. Box 950, Mailstop H6-08, Richland WA 99352, Phone (509) 372-2420; Fax (509) 376-4989

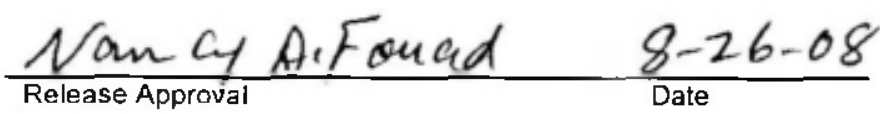

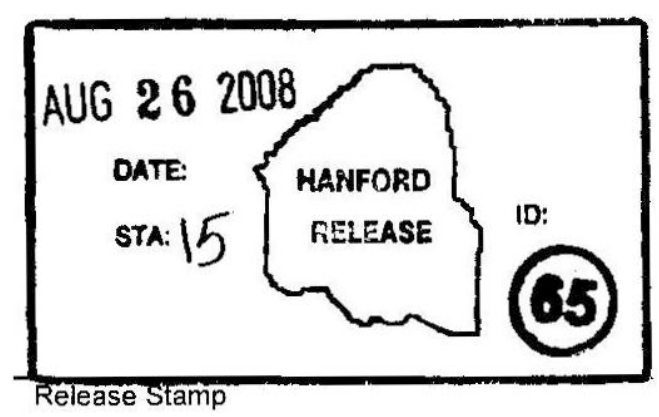

\section{Approved For Public Release}




\begin{tabular}{|c|c|c|c|}
\hline \multicolumn{2}{|r|}{$\begin{array}{l}\text { Tank Farm Contractor (TFC) } \\
\text { RECORD OF REVISION }\end{array}$} & $\begin{array}{l}\text { (1) Document Number: } \\
\text { RPP-ENV-37956 }\end{array}$ & Page 1 \\
\hline \multicolumn{4}{|l|}{$\begin{array}{l}\text { (2) Title: } \\
\text { Hanfor }\end{array}$} \\
\hline \multicolumn{4}{|c|}{ Change Control Record } \\
\hline \multirow{2}{*}{$\begin{array}{c}\text { (3) } \\
\text { Revision }\end{array}$} & \multirow{2}{*}{ (4) Description of Change - Replace, Add, and Delete Pages } & \multicolumn{2}{|c|}{ Authorized for Release } \\
\hline & & (5) Resp. Engr. (print/sign/date) & (6) Resp. Mgr. (print/sign/date) \\
\hline 0 & Initial Release of Document & & \\
\hline RS & $\begin{array}{l}\text { Pages } 23,25,32 \text {, and } 37 \text { : Corrected description of lateral } \\
\text { surveys that were performed in } 2005 \text { for tanks A-103, A- } \\
104 \text {, and A-105. Gross gamma surveys were performed; } \\
\text { not spectral gamma surveys. }\end{array}$ & 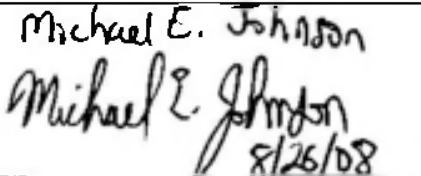 & 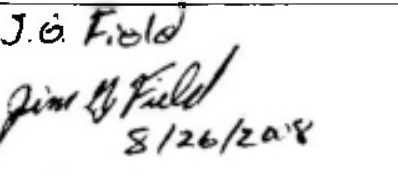 \\
\hline
\end{tabular}




\title{
HANFORD A AND AX-FARM LEAK ASSESSMENTS REPORT: 241-A-103, 241-A-104, 241-A-105, 241-AX-102, 241-AX-104 AND UNPLANNED WASTE RELEASES
}

\author{
M. E. Johnson
}

CH2M HILL Hanford Group, Inc.

Date

August 2008

\section{CIn2NMHILL \\ Hanford Group. Inc.}

Post Office Box 1500

Richland, Washington

Prepared for the U.S. Department of Energy

Office of River Protection

Approved for public release; distribution unlimited 


\section{CONTENTS}

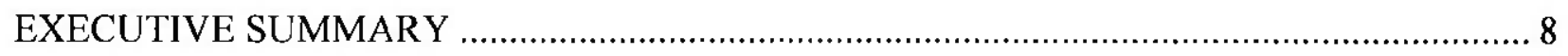

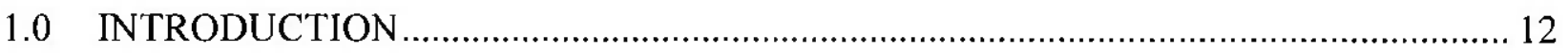

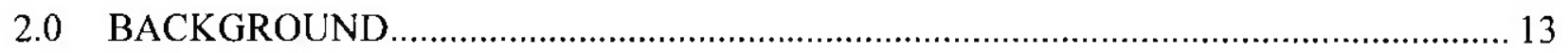

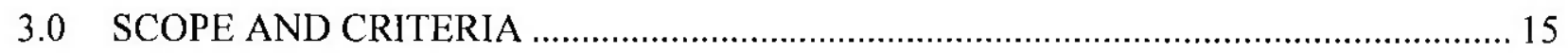

4.0 REASSESSMENT 241-A AND 241-AX TANK FARMS WASTE LOSS EVENTS ...... 16

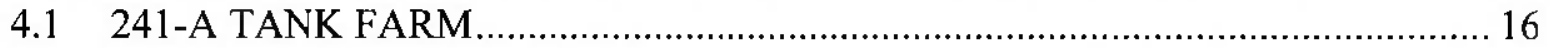

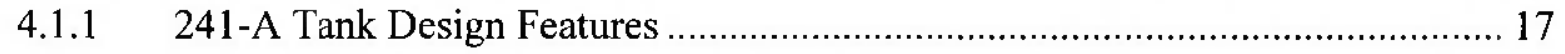

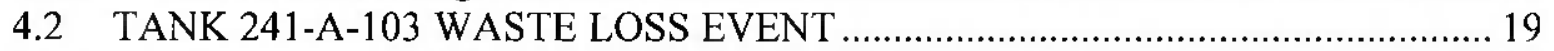

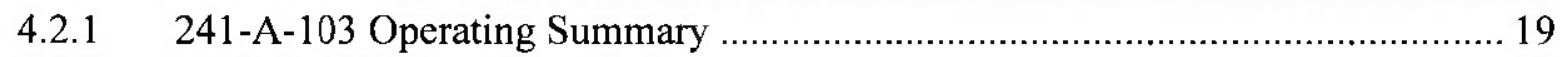

4.2.2 Tank A-103 Waste Loss Estimate .................................................................... 21

4.2.3 A-103 Conclusions........................................................................................... 23

4.3 TANK 241-A-104 WASTE LOSS EVENT ….................................................. 23

4.3.1 241-A-104 Operating Summary .................................................................... 23

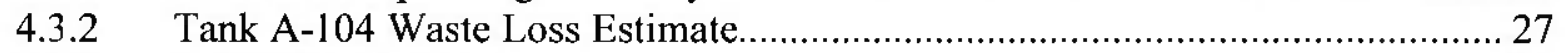

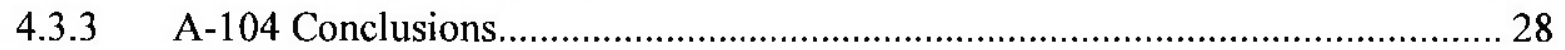

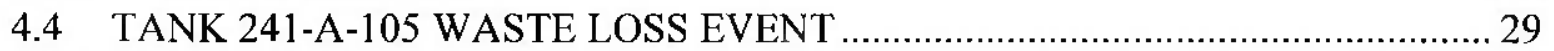

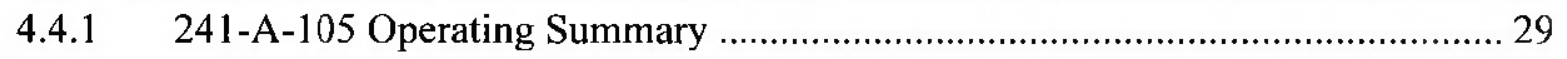

4.4.2 Nature and Extent of Contamination at Tank A-105 ....................................... 32

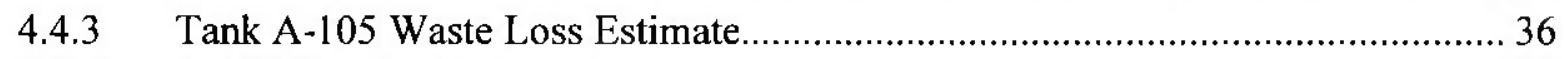

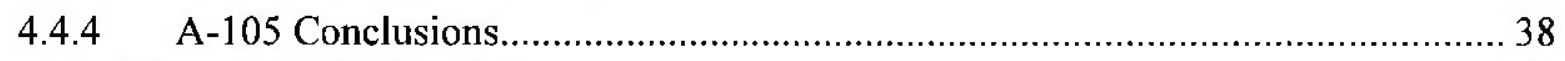

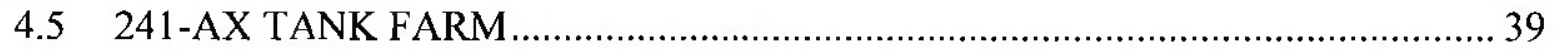

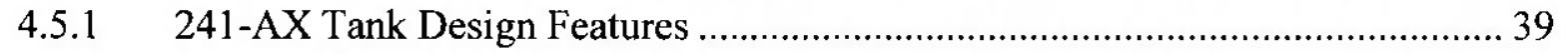

4.5.2 241-A and 241-AX Tank Farm Process Condensate ............................................ 40

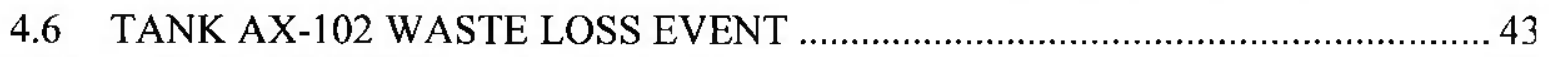

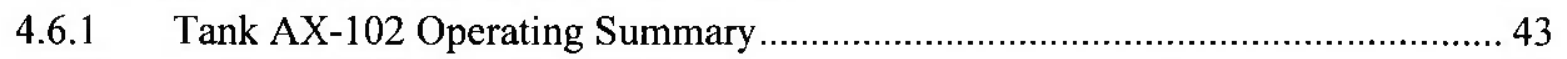

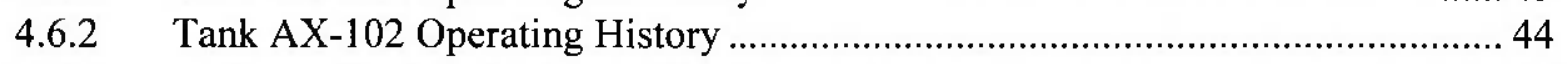

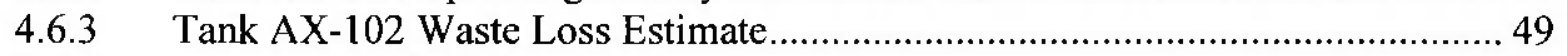

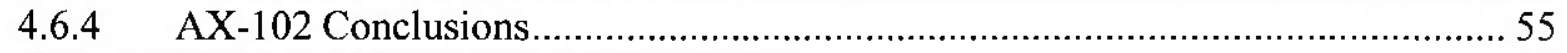

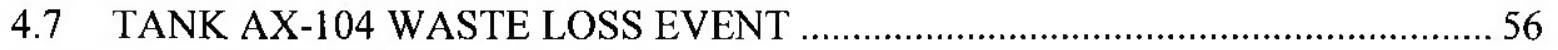

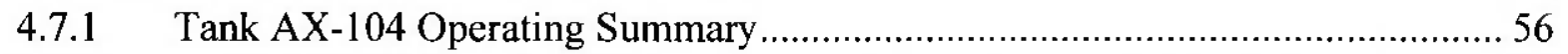

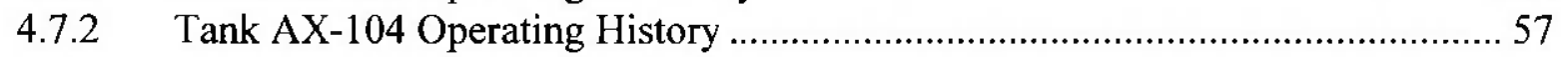

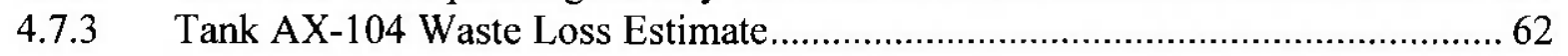

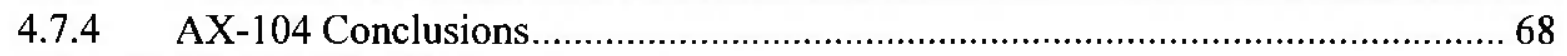

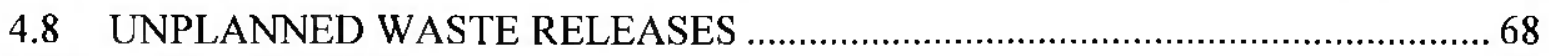

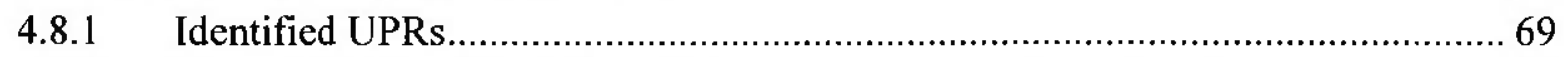

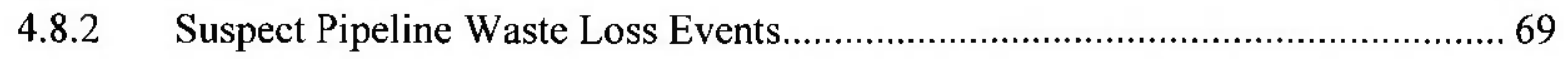

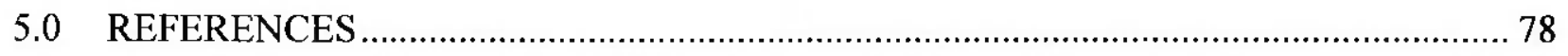

APPENDIX A MEETING SUMMARIES ................................................................... 92 


\section{List of Figures}

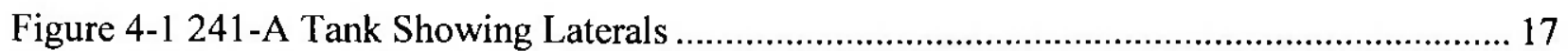

Figure 4-2 Location of Drywells and Laterals in 241-A Farm ............................................ 18

Figure 4-3 Typical Dresser Coupling ............................................................................. 19

Figure 4-4 Location of Peak Readings in Tank A-104 Laterals ............................................. 25

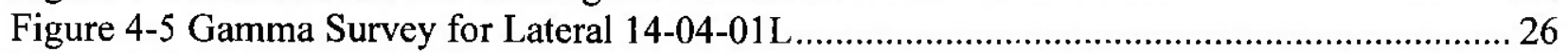

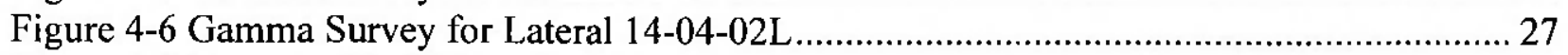

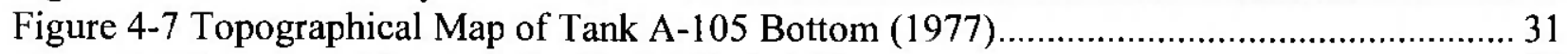

Figure 4-8 Location of Laterals for Tank 241-A-105 …................................................... 33

Figure 4-9 Summary Gamma Survey for the Laterals under Tank A-105 .............................. 34

Figure 4-10 Spectral Gamma Log of Drywell 10-06-09 ....................................................... 35

Figure 4-11 Spectral Gamma Log of Drywell 10-05-12 …................................................... 36

Figure 4-12 241-AX Tank and Leak Detection Pit.......................................................... 40

Figure 4-13 Tank AX-102 Operational Timeline $(1965-1988)$......................................... 44

Figure 4-14 Historical Gross Gamma Log Data from Drywell 11-02-12 ............................... 51

Figure 4-15 Gamma Logging Results for Drywells 11-02-01 thru 11-02-05 ........................... 52

Figure 4-16 Gamma Logging Results for Drywells 11-02-01 thru 11-02-05........................... 53

Figure 4-17 Repeated Gamma Logging for Drywell 11-02-12 (2 Sheets) ................................ 54

Figure 4-18 Tank AX-104 Operational Timeline $(1965$ - 1981) ............................................ 57

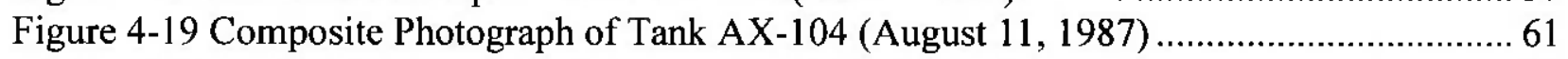

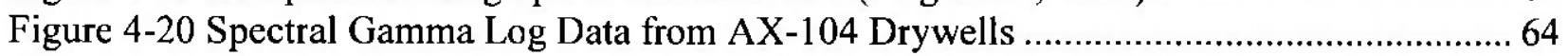

Figure 4-21 Historical Gross Gamma Log Data from Drywell 110411 ................................6 66

Figure 4-22 Historical Gross Gamma Log Data from Drywell 110401 ................................. 67 


\begin{tabular}{|c|c|}
\hline $1 \mathrm{C}$ & first decontamination cycle waste from bismuth phosphate plant \\
\hline bgs & below ground surface \\
\hline Btu & British thermal unit \\
\hline cal & calories \\
\hline $\mathrm{Ci}$ & curies \\
\hline $\mathrm{cfm}$ & cubic feet per minute \\
\hline $\mathrm{cm}$ & centimeter \\
\hline $\mathrm{c} / \mathrm{m}$ & counts per minute \\
\hline $\mathrm{COC}$ & contaminant of concern \\
\hline $\mathrm{c} / \mathrm{s}$ or $\mathrm{cps}$ & counts per second \\
\hline CSR & cesium removal waste \\
\hline $\mathrm{CW}$ & cladding (or coating) removal waste \\
\hline DST & double-shell tank \\
\hline $\mathrm{ECN}$ & engineering change notice \\
\hline $\mathrm{FeCN}$ & ferrocyanide waste \\
\hline $\mathrm{ft}$ & feet \\
\hline gal & gallon \\
\hline g or gm & gram \\
\hline $\mathrm{H}$ or hr & hour \\
\hline $\mathrm{HLO}$ & Hanford Laboratory Operations (defunct organization) \\
\hline HLW & high-level waste \\
\hline HPT & health protection technician \\
\hline HRR & high resolution resistivity \\
\hline $\mathrm{HS}$ & Hot Semiworks building $201-\mathrm{C}$ \\
\hline IDMS & Integrated Data Management System \\
\hline in. & inch \\
\hline IX & ion exchange \\
\hline $\mathrm{kCi}$ & kilocuries \\
\hline $\mathrm{kg}$ & kilogram \\
\hline $\mathrm{kW}$ & kilowatts \\
\hline lbs & pounds \\
\hline MW & $\begin{array}{l}\text { Metal waste; high-level waste containing fission products and uranium derived from } \\
\text { reprocessing spent nuclear fuel using the bismuth phosphate process }\end{array}$ \\
\hline ORNL & Oak Ridge National Laboratory \\
\hline OWW & organic wash waste \\
\hline$\underline{\mathrm{Pl}}$ & PUREX HLW supernate also referred to as PSN waste type \\
\hline $\mathrm{pCi}$ & pico-curies \\
\hline PNNL & Pacific Northwest National Laboratory \\
\hline PSN & PUREX supernate neutralized also referred to as PI waste type \\
\hline PSS & PUREX sludge supernate \\
\hline PUREX & Plutonium Uranium Extraction \\
\hline r or rad & radiation absorbed dose \\
\hline $\mathrm{RSN}$ & REDOX neutralized supernate \\
\hline SIM & Soil Inventory Model \\
\hline SGE & Surface Geophysical Exploration \\
\hline SST & single-shell tank \\
\hline TBP & Tri-Butyl Phosphate \\
\hline TFeCN & tank farm ferrocyanide waste \\
\hline TWINS & Tank Waste Information Network System \\
\hline UPR & Unplanned Release \\
\hline UR & Uranium Recovery waste, same as TBP waste \\
\hline W & watts \\
\hline
\end{tabular}




\section{Executive Summary}

CH2M HILL Hanford Group Inc. developed jointly with DOE-ORP and Washington Department of Ecology (Ecology) a process to re-assess selected tank leak estimates (volumes and inventories) and to update single-shell tank (SST) leak and unplanned releases (UPRs) volumes, and inventory estimates as emergent field data is obtained (RPP-32681, 2007, Process to Estimate Tank Farm Vadose Zone Inventories). This process does not represent a formal tank leak assessment in accordance with procedure TFC-ENG-CHEM-D-42, Tank Leak Assessment Process. The SSTs and UPRs in WMA A and AX, which encompasses the 241-A and 241-AX Tank Farms, were selected for this re-assessment as documented in this report.

Tank waste loss events were re-assessed for SSTs 241-A-103, 241-A-104, 241-A-105, 241$\mathrm{AX}-102$, and $241-\mathrm{AX}-104$, which have previously been designated as suspected of having leaked waste to the ground. Table ES-1 summarizes the results of the re-assessment of tank waste loss events for these five SSTs and provides a comparison to the waste loss estimates contained in HNF-EP-0182, rev. 238 Waste Tank Summary Report for Month Ending January 31, 2008. Where known, the estimated volume of waste lost and the waste type can be used to derive an estimated inventory of constituents using the Hanford Soil Inventory Model, Rev. 1 (RPP26744).

DOE/RL-88-30, rev. 16, 2007, Hanford Site Waste Management Units Report, contains the official listing of UPRs identified at the Hanford site. The operational histories for the 241-A and 241-AX Tank Farms were reviewed to determine if additional information exists for the UPRs within WMA A and AX not associated with tank waste loss events. No significant new information was located for these UPRs. However, potentially new UPRs as a result of pipeline failures were identified through review of the operational histories for these tank farms, as summarized in Table ES-2. Insufficient information was available to estimate a volume of inventory of tank waste potentially discharged to the soil from most of the identified pipeline failures. In general these pipelines leaks would be significantly smaller than the estimated volume of waste leaked from the tanks. 


\begin{tabular}{|c|c|c|c|}
\hline \multicolumn{4}{|c|}{ Table ES-1. Summary of Tank Waste Loss Events } \\
\hline Tank & Analysis & $\begin{array}{c}\text { HNF-EP-0182 } \\
\text { Estimate } \\
\text { (gallons) }\end{array}$ & $\begin{array}{l}\text { Current } \\
\text { Estimate } \\
\text { (gallons) }\end{array}$ \\
\hline A- 103 & $\begin{array}{l}\text { From October } 8,1981 \text { to March } 5,1987 \text {, the liquid level in tank } \\
\text { A- } 103 \text { was observed to have decreased an estimated } 5,500 \text { gallons. } \\
\text { However, the liquid waste level in tank A- } 103 \text { would also slowly rise } \\
\text { over a period of } 9 \text { to } 12 \text { months, then drop rapidly over one to two day } \\
\text { period. The liquid level decline may have been due to retained gas } \\
\text { release and not a loss of waste. No increase in radioactivity was } \\
\text { detected in drywells or laterals beneath this tank during these events. } \\
\text { Assessment team members concluded there is no evidence tank A-103 } \\
\text { lost containment. }\end{array}$ & 5,500 & 0 \\
\hline A- 104 & $\begin{array}{l}\text { The Hanford site tank farm contractor in correspondence with the U.S. } \\
\text { Energy Research and Development Administration reported an } \\
\text { estimated waste loss of } 700 \text { to } 1,500 \text { gallons in July } 1975 \text {. In } \\
\text { September } 1975 \text {, the Hanford site tank farm contractor conducted a } \\
\text { study at tank } 104-A \text { to re-evaluate the leak size and revised the } \\
\text { estimated leak loss to approximately } 2,000 \text { gallons. } \\
\text { The waste type leaked from tank A-104 is PUREX Sludge Supernate } \\
\text { (PSS), containing } \sim 0.56 \mathrm{Ci} / \text { gal Cs }^{137} \text { as of May } 2008 \text {. }\end{array}$ & 500 to 2,500 & 2,000 \\
\hline$\overline{A-105}$ & $\begin{array}{l}\text { At least three leak events occurred with tank A-105. PUREX HLW } \\
\text { supernate (PI waste type) leaked from this tank in late } 163 \text { and again } \\
\text { in } 1965 \text {. During sluicing in } 1968-1970, B \text { Plant cesium ion exchange } \\
\text { waste (waste type BIX) also leaked form this tank In an effort to better } \\
\text { quantify the inventory of waste leaked from tank A-105, a new } \\
\text { conceptual model was devised to describe the leak. Based on this } \\
\text { conceptual model the range of waste volume leaked from tank A-105 } \\
\text { was estimated to be a between } 2,000 \text { gallons of P1 waste and } 40,000 \\
\text { gallons of BIX waste. Estimated leak volumes for the individual } \\
\text { waste type can not be made with currently available information. }\end{array}$ & $\begin{array}{l}10,000 \text { to } \\
277,000^{1}\end{array}$ & $\begin{array}{l}2,000 \text { to } 40,000 \\
\text { plus cooling } \\
\text { water }{ }^{1}\end{array}$ \\
\hline AX-102 & $\begin{array}{l}\text { The assessment team has determined the estimated waste loss of } \\
3,400 \text {-gallons from tank } 241-\mathrm{AX}-102 \text { is inconsistent with the } \\
\text { relatively low level of radiation detected in the leak detection pit and } \\
\text { drywells associated with this tank. The likely source of radioactivity } \\
\text { detected historically in drywells } 11-02-11 \text { and } 11-02-12 \text { is the leaking } \\
\text { Dresser coupling associated with the tank offgas piping. }\end{array}$ & 3,000 & 0 \\
\hline AX-104 & $\begin{array}{l}\text { It is doubtful that PSS waste leaked from tank } 241-\mathrm{AX}-104 \text {. The } \\
\text { likely source of radioactivity detected historicaily in drywells } 11-04- \\
01 \text { and } 11-04-11 \text { is the leaking Dresser coupling associated with the } \\
\text { tank offgas piping. The source of the historical }{ }^{116} \mathrm{Ru} \text { radioactivity } \\
\text { detected in drywells } 11-04-08 \text { and } 11-04-19 \text { can not be definitively } \\
\text { determined, but could be from migration of contamination associated } \\
\text { with the Dresser coupling leaks or nearby condensate lines which may } \\
\text { have leaked. }\end{array}$ & $\ldots$ & indeterminate \\
\hline
\end{tabular}

\footnotetext{
' Includes cooling water potentially leaked from tank. HNF-EP-0182 estimates 610,000 gallons of cooling water were added to tank A-105 from Novernber 1970 to December 1978 to aid in evaporative cooling. Approximately 232,000 gallons of added cooling water are potentially unaccounted for in the estimate of evaporative water. In accordance with Dangerous Waste Regulations [Washington Administrative Code 173-303-070 (2)(a)(ii), as amended, Washington State Department of Ecology, 1990, Olympia, Washington], any of this cooling water that has been added and subsequently leaked from the tank must be classified as a waste and should be included in the total leak volume.
} 
RPP-ENV-37956 Rev. 1

Table ES-2. Potential Pipeline Failures Not Previously Reported in DOE/RL-88-30, revision 16

\begin{tabular}{|c|c|c|c|}
\hline Date & Event & Reference & Comments \\
\hline $10-1957$ & $\begin{array}{l}\text { Tank } 433 \text { and connecting pipelines were reported as being } \\
\text { failed and leaking contamination. }\end{array}$ & $\begin{array}{l}\text { HW-53449 pages C-3 and C-5 } \\
\text { HW-53967 page C-3 }\end{array}$ & $\begin{array}{l}\text { The Tank } 433 \text { is located in the } 241-\mathrm{A}-413 \text { Fan House } \\
\text { building nearby SST A-103. }\end{array}$ \\
\hline $11-1964$ & $\begin{array}{l}\text { Several hundred gallons of condensed vapors from the } 241 \text { - } \\
\text { A waste storage tanks were pumped out of a stub on the } \\
\text { west side of the } 417 \text {-A jumper pit. }\end{array}$ & RL-SEP-1 12 page B-3 & \\
\hline $1-28-1965$ & $\begin{array}{l}\text { Construction forces were preparing to make the final weld } \\
\text { in a line to tie tank 105-A into the 151-AX diverter station. } \\
\text { The line was observed to shake and liquid spill out on to the } \\
\text { ground in the excavation as a result of a pressurization } \\
\text { event in tank A-105. }\end{array}$ & WHC-MR-0250 page A-10 & \\
\hline $2-1965$ & $\begin{array}{l}\text { On February } 18,1965 \text { the } 244-C R \text { Vault was found flooded } \\
\text { up to approximately the level of the tank tops. Partial cause } \\
\text { of the flooding is attributed to a failure in the coating waste } \\
\text { line which enters the } 151-C R \text { diversion box. In trying to } \\
\text { establish a coating waste routing from the Purex Plant to the } \\
241 \text {-C Tank Farm a leak was also discovered in the } \\
\text { underground line adjacent to the } 152 \text {-A Diversion Box. }\end{array}$ & RL-SEP-332 page B-2 & $\begin{array}{l}\text { Failed line is } 8041 \text { per drawing H-2-2338, sheet } 45 \text {, } \\
\text { Diversion Box } 241 \text {-CR-152 Nozzle Information. Line } \\
\text { V8107 replaced the failed line } 8041 \text { per drawing H- } \\
2-33087, L N 8107 \text { (24I-CR-152 TO 102C) V843 \& } \\
\text { V844 (241-CR-151 TO 102C) V050 \& V051 (24l-A- } \\
\text { 152 TO I04C). }\end{array}$ \\
\hline $6-1966$ & $\begin{array}{l}\text { Approximately } 20 \text { gallons of } 103-\mathrm{AX} \text { contents were spread } \\
\text { on the } 801-\mathrm{A} \text { Control Building floor during replacement of } \\
\text { a portion of the piping to circulator } 10 \text {. }\end{array}$ & ISO-75 RD page 99 & $\begin{array}{l}\text { The AX-801A instrument building was } \\
\text { decontaminated, with flush solutions initially } \\
\text { discharged to open trenches dug outside the building. } \\
\text { These trenches were backfilled with three feet of } \\
\text { earth cover. }\end{array}$ \\
\hline $1-29-68$ & $\begin{array}{l}\text { Liquid noticed coming from underground near 103-AX } \\
\text { pump pit. }\end{array}$ & ARH-258 page 40 & \\
\hline 1968 & $\begin{array}{l}\text { In } 1968, \text { the } 1.5 \text {-inch steam condensate line was abandoned } \\
\text { in place and replaced by a new } 4 \text {-inch direct buried } \\
\text { pipeline. This new } 4 \text {-inch pipeline routed steam condensate } \\
\text { from two coils in tanks } 241 \text {-AX-101 and one coil in tank }\end{array}$ & $\mathrm{H}-2-58896$ and $\mathrm{H}-2-34266$ & \\
\hline
\end{tabular}


RPP-ENV-37956 Rev. I

Table ES-2. Potential Pipeline Failures Not Previously Reported in DOE/RL-88-30, revision 16

\begin{tabular}{|c|c|c|c|}
\hline $1-1975$ & $\begin{array}{l}\text { Leakage of condensate from } 241-\mathrm{AX} \text { offgas header Dresser } \\
\text { couplings }\end{array}$ & $\begin{array}{l}\text { IDMS Accession \# } \\
\text { D195006631 }\end{array}$ & $\begin{array}{l}\text { Dresser couplings were installed on the } 241-\mathrm{A} \text { and } \\
241-\mathrm{AX} \text { vapor header system. Deterioration and } \\
\text { leak from the Dresser couplings could have occurred } \\
\text { throughout the operational life of these tank farms } \\
\text { (i.e. } 1956-1980 \text { ). }\end{array}$ \\
\hline $3-25-1980$ & $\begin{array}{l}\text { On March } 25,1980 \text {, a routine pressure test of the F-100 } \\
\text { condensate return line (buried) from } 501-A X \text { valve pit to } \\
\text { the } 417 \text { condensate catch tank (i.e. TK-A-417) failed. } \\
\text { Investigation on April } 3,1980 \text { revealed a leak at a flange } \\
\text { connection adjacent to the } 417 \text { Tank. }\end{array}$ & $\begin{array}{l}\text { IDMS Accession \# } \\
\text { D197182689 }\end{array}$ & $\begin{array}{l}\text { The line was excavated and contaminated soil was } \\
\text { removed to the burial ground. The leak was } \\
\text { determined to be at a gasket on a flange on this } \\
\text { pipeline. }\end{array}$ \\
\hline
\end{tabular}




\subsection{INTRODUCTION}

There have been numerous studies and investigations in an attempt to estimate the inventory of contaminants in the tank farms vadose zone. Most effort to date has focused on leak volume estimates. Vadose zone inventories are then estimated by multiplying the leak volume by the contaminant concentration in the leak. This concentration is based on process knowledge of the composition of waste in the tank at the time the release occurred. For some major tank leaks and unplanned releases (UPRs), historical records confirm the waste loss event and provide a strong technical basis for leak volume and inventory estimates. However, for many tank leaks and UPRs little data is available.

The Tank Waste Summary Report (HNF-EP-0182) provides the commonly accepted basis for tank leak volume estimates, but it does not provide associated inventory estimates or UPR volumes. Tank leak volume estimates reported in HNF-EP-0182 have not been updated for many years. The Tank Farm Vadose Zone Contamination Estimates (RPP23405) summarizes vadose zone tank leak characterization and investigations. It is consistent with many of the tank leak volume estimates listed in HNF-EP-0182 and provides UPR volume estimates. However, RPP-23405 shows large differences in estimated leak volumes, both higher and lower, compared to some tank leak volume estimates in HNF-EP-0182. The RPP-23405 volume estimates were used in the Hanford Soil Inventory Model, Rev. 1 (SIM) (RPP-26744) to estimate leak inventories for the Initial Single-Shell Tank System Performance Assessment for the Hanford Site (DOE/ORP-2005-01). RPP-23405 does not address volume uncertainties and some of the leak volume estimates, data interpretations, and conclusions presented in RPP-23405 are in question.

CH2M HILL Hanford Group Inc. developed jointly with DOE-ORP and Washington Department of Ecology (Ecology) a process to re-assess selected tank leak estimates (volumes and inventories) and to update tank leak and UPR volumes, and inventory estimates as emergent field data is obtained (RPP-32681, 2007, Process to Estimate Tank Farm Vadose Zone Inventories). This process does not represent a formal tank leak assessment in accordance with procedure TFC-ENG-CHEM-D-42, Tank Leak Assessment Process. This report documents the results of applying the process described in RPP-32681 for re-assessing UPRs and tank leak estimates for single-shell tanks (SSTs) in the 241-A and 241-AX tank farms. This revision of this report contains the re-assessment for SSTs 241-A-103, 241-A-104, 241-A-105, 241-AX-102 and 241-AX104 , as well as UPRs within these tank farms. 


\subsection{BACKGROUND}

Approximately 53 million gallons of radioactive waste from chemical processing and plutonium processing operations are stored in 177 underground storage tanks on the Hanford Site. Of these, 149 are SSTs, which consist of a single steel liner inside a concrete shell. Nominal capacities range from 55,000 to 1,000,000 gallons. For the immediate future, plans call for retrieval of waste from the SSTs and transfer to the 28 double-shell tanks (DST), with eventual transfer for treatment in the Waste Treatment and Immobilization Plant.

Sixty-seven of 149 SSTs have been identified as "confirmed or suspected leakers" over the operational lifetime (1945 - 1980) of the SST farms (HNF-EP-0182). Historically, SST integrity was assessed by two independent methods. From the beginning of Hanford Site tank farm operations, the primary leak detection system was routine monitoring of liquid-surface levels within each tank. Originally liquid levels were measured using pneumatic dip tubes (HW-10475-C, Hanford Technical Manual Section C page 908). This practice was later replaced and a manual tape with a conductivity electrode was used to detect the liquid surface (H-2-2257, 1951, Conductor Reel for Liquid Level

Measurement). The biggest limitations of the manual tape measurements were failures of the electrodes, solids forming on the electrode and measurement precision. The statistical accuracy of the manual tape and electrode measurement technique was 0.75 in. $(\sim 2,060$ gallons), as determined in July 1955 (HW-51026, 1957 page 4, Leak Detection Underground Storage Tanks, General Electric Company, Richland WA). Later, liquidlevel determinations were automated in many of the SSTs to provide more accurate and reliable measurements. However, surface-level measurements remain highly uncertain in the waste tanks that contained boiling wastes (e.g. 241-A, 241-AX, and 241-SX tank farms), when supernatant has been removed from tanks leaving solids or precipitated salts, or where solid crusts have formed on the waste surfaces.

Routine monitoring of gross gamma activity in drywells near the SSTs provided a secondary leak detection method. For 241-A SSTs and some 241-SX SSTs, laterals were installed approximately 10 - $\mathrm{ft}$ beneath the tank bottom for gross gamma monitoring beneath these tanks. Additionally, the four 241-AX SSTs were uniquely equipped among the SSTs with a network of drain slots in the concrete base beneath the steel tank liner. These drain slots were intended to channel liquid from beneath the steel tank liner to a 60 -ft deep leak detection pit; one pit per tank. As with the tank waste surface-level measurements, there are uncertainties associated with these secondary leak detection methods. Three sources of uncertainty are as follows:

1. Number and location of wells / laterals / leak detection pits: There were rarely more than 6 drywells surrounding the 100-series SSTs (circumference approximately 235 $\mathrm{ft}$ ). With the exception of tank SX-113 which has five laterals, there are 3 laterals beneath tanks SX-105 thru SX-115 and 241-A-101 thru 241-A-106. The location and number of laterals did not represent full coverage beneath these SSTs. Similarly, the leak detection pits only collect leakage from the bottom area of the 241-AX tanks and 
not the side walls. Consequently, the absence of gamma activity in a well, lateral, or leak detection pit does not necessarily indicate that a tank did not leak.

2. Waste type: The overall effectiveness of gross gamma logging in drywells as a leak detection system depends on the waste type in the tank. The gross gamma logging system is most effective with waste types containing high concentrations (activities) of mobile gamma emitting radionuclides (e.g. $\mathrm{Ru}-106$ or $\mathrm{Co}-60$ ) and large releases and less effective with low-activity waste types such as aluminum cladding waste.

3. Other contamination sources: Gamma activity observed in drywells may also have originated from near-surface waste loss events, transfer line leaks, and tank overfills.

During the active operation of the SST farms, either an anomalous liquid-level measurement or a significant increase in gamma activity in a drywell, lateral, or leak detection pit was generally sufficient reason for the tank to be listed as "questionable integrity" or an "assumed leaker" as discussed in SD-WM-TI-356, Waste Storage Tank Status and Leak Detection Criteria. When a tank was designated as "questionable integrity" it was pumped to a "minimum heel" and taken out of service. In a limited number of cases the "questionable integrity" designation was followed up with additional investigations. However, in many cases no additional investigations were performed. In the late $1980 \mathrm{~s}$, all SSTs that had been flagged as potential or known leakers were combined into the list contained in the monthly waste tank summary report (HNF-EP0182) and flagged as "confirmed or assumed leakers." Because of the uncertainty associated with the measurements, unexplained waste level decreases were generally considered as an inadequate basis for designating a tank as a "confirmed leaker." The "confirmed leaker" designation required an observed waste level decrease combined with increasing gamma activity in a nearby drywell. The "assumed leaker" designation could be assigned based on either measurement (an observed waste level decrease or increasing gamma activity in a nearby drywell), without confirmation from the other measurement.

The uncertainties, associated with both the primary and secondary leak detection systems for the SSTs, led to a number of decisions. By the early $1960 \mathrm{~s}$, decisions were made to move from the single-shell tanks to the double-shell tank design. The double-shell design provided both secondary containment and reliable leak detection systems. A decision was also made to pump liquids stored in the SSTs into the DSTs to remove pumpable liquid and interim stabilize the SSTs. 


\subsection{SCOPE AND CRITERIA}

An assessment team comprised of representatives from DOE-ORP, Ecology, and CH2M HILL Hanford Group, Inc. was assembled to review available information relating to waste loss events in the 241-A and 241-AX Tank Farms. The assessment team membership is listed in Table 3-1. Minutes from team meetings are included in APPENDIX A MEETING SUMMARIES.

Table 3-1 WASTE LOSS EVENT ASSESSMENT TEAM

\begin{tabular}{|c|c|c|}
\hline Name & Organization & Role \\
\hline Joe Caggiano & $\begin{array}{l}\text { Washington State Department of } \\
\text { Ecology }\end{array}$ & Regulatory oversight \\
\hline Michael Connelly & CH2M HILL Hanford Group Inc. & $\begin{array}{l}\text { Knowledge and experience in } \\
\text { reviewing, analyzing, and } \\
\text { interpreting drywell, lateral } \\
\text { survey, and High Resolution } \\
\text { Resistivity (HRR) data. }\end{array}$ \\
\hline Jim Field & CH2M HILL Hanford Group Inc. & $\begin{array}{l}\text { Contractor manager for process } \\
\text { Knowledge and experience in } \\
\text { reviewing, analyzing, and } \\
\text { interpreting in-tank (i.e., surface } \\
\text { liquid level and liquid } \\
\text { observation well) data. }\end{array}$ \\
\hline Les Fort & $\begin{array}{l}\text { Washington State Department of } \\
\text { Ecology }\end{array}$ & Regulatory oversight \\
\hline Michael E. Johnson & CH2M HILL Hanford Group Inc. & $\begin{array}{l}\text { Knowledge and experience with } \\
\text { operations of the tank farm and } \\
\text { individual tank, tank history, tank } \\
\text { waste characteristics, and in-tank } \\
\text { processes. }\end{array}$ \\
\hline $\begin{array}{l}\text { Bob W. Lober } \\
\text { (did not attend meetings) }\end{array}$ & $\begin{array}{l}\text { U.S. Department of Energy } \\
\text { Office of River Protection }\end{array}$ & $\begin{array}{l}\text { Tank Farms Programs and Project } \\
\text { Division representative }\end{array}$ \\
\hline Beth Rochette & $\begin{array}{l}\text { Washington State Department of } \\
\text { Ecology }\end{array}$ & $\begin{array}{l}\text { Regulatory oversight } \\
\text { (primary interest in UPRs and } \\
\text { direct exposure pathway) }\end{array}$ \\
\hline Marcus I. Wood & Fluor Hanford & $\begin{array}{l}\text { Knowledge and experience in } \\
\text { reviewing, analyzing, and } \\
\text { interpreting drywell and } \\
\text { groundwater monitoring data. }\end{array}$ \\
\hline
\end{tabular}


In accordance with RPP-32681, the following steps were conducted in reassessing waste losses within the 241-A and 241-AX Tank Farms:

- Data regarding any waste leaks from ancillary equipment in the area of the facility being reassessed are collected, as well as any reported unplanned releases (UPRs).

- Data regarding any past or present waste leaks from tanks, as well as any reported UPRs, are collected, and collated with any reported ancillary equipment waste leaks.

- All of the information from previously reported waste tank leaks and UPRs are compiled to determine the best estimation of the volumes of tank waste which leaked to the vadose zone and the time at which these leaks occurred.

- Data regarding the waste composition at the time of the leak from the waste tank, ancillary equipment or UPR is compiled from the available sources, such as Tank Waste Information System Best Basis Inventory, Hanford Defined Waste model etc., and is applied to the facility being reassessed.

- The waste leak volume estimates are combined with the waste compositions at the time of leak to determine the best estimation of the radionuclide and chemical inventory which entered the soil.

\subsection{REASSESSMENT 241-A AND 241-AX TANK FARMS WASTE LOSS EVENTS}

The information gathered and the reassessment results for each of the SSTs and UPRs in the 241-A and 241-AX Tank Farms are discussed in this section. Several processes were conducted at the Hanford site that generated wastes transferred to the 241-A and 241-AX Tank Farms. These processes and the waste types generated are discussed in the Standard Inventories of Chemicals and Radionuclides in Hanford Tank Wastes (HNFSD-WM-TI-740).

\subsection{1-A Tank Farm}

The 241-A tanks were designed for the storage of boiling waste generated from irradiated fuel reprocessing at the 202-A PUREX Plant. The 241-A tanks have three unique design features which are airlift circulators for cooling the boiling wastes, an underground vessel ventilation header to remove condensate and volatiles, and laterals $10-\mathrm{ft}$ beneath the tank for leak detection. These unique design features are discussed further in section 4.1.1. An understanding of the 241-A tank design features aides in the discussion of the historical waste loss events associated with tanks 241-A-103 (section 4.2), 241-A-104 (section 4.3) and 241-A-105 (section 4.4), as well as the unplanned waste release events in the 241-A and 241-AX Tank Farms (section 4.8). 


\subsubsection{1-A Tank Design Features}

The 241-A Tank Farm contain respectively six nominally 1,000,000 gallon capacity SSTs, as shown in Figure 4-1 (H-2-31880). The 241-A tanks consist of a 75-ft diameter, carbon steel liner inside a concrete tank. The tank steel bottoms intersected the sidewalls orthogonally (similar to 241-AX and 241-SX tanks), rather than the dished bottoms of earlier designed tank farms. The concrete thickness is $0.5-\mathrm{ft}$ on the tank bottom, 2 - $\mathrm{ft}$ to 1.25 -ft on the side walls, and 1.25-ft for the tank dome. The concrete tank dome thickness increases to $\sim 3.5$-ft along the sidewalls. Each tank was originally equipped with 9 to 11 risers and a 20 -inch diameter vapor exhaust pipeline that penetrated the tank dome and 4 airlift circulators that were operated to suspend solids, mix the tank contents, and dissipate heat.

Figure 4-1 241-A Tank Showing Laterals

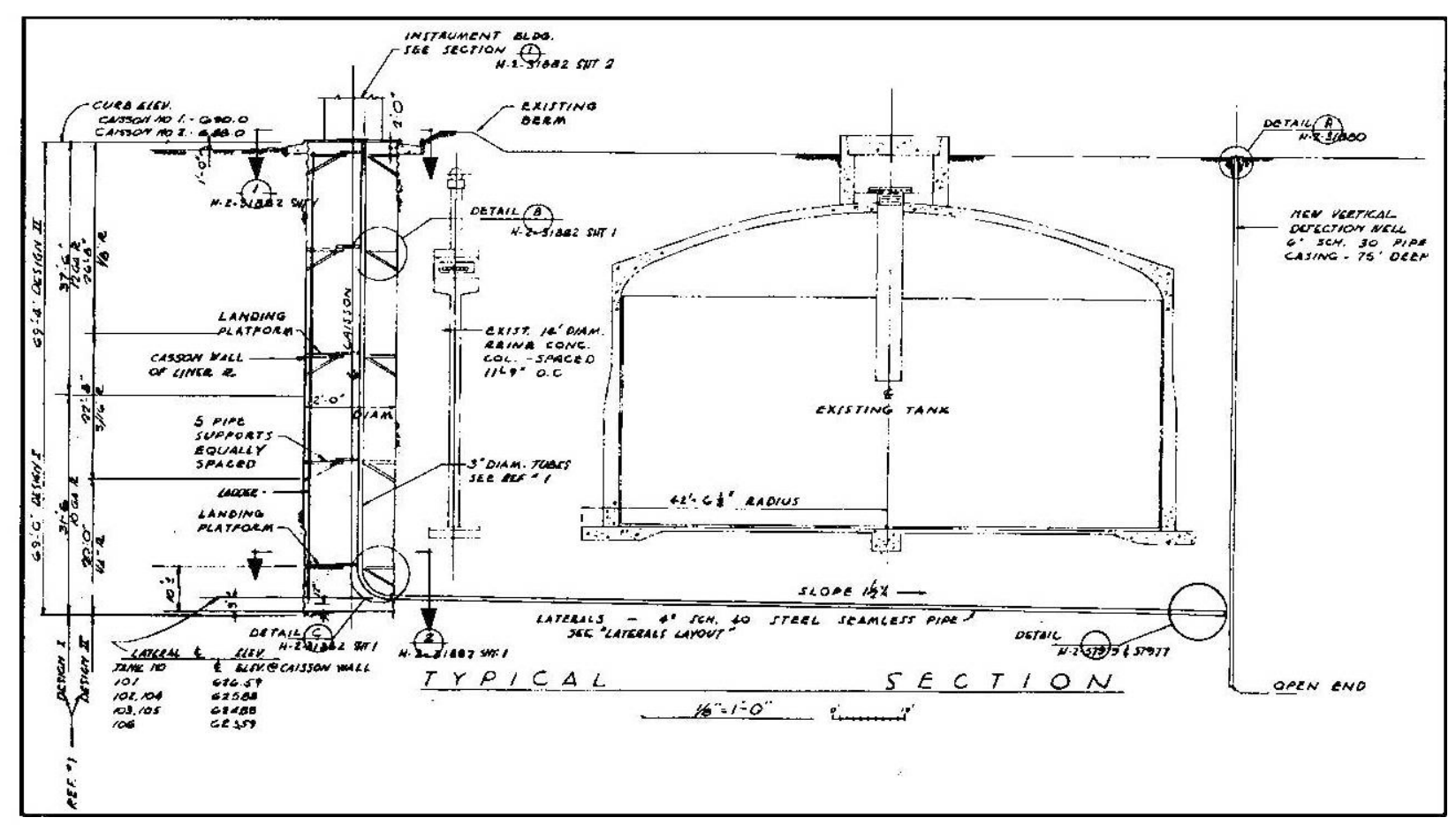

The 241-A tanks were originally designed to contain liquid and solid wastes at a maximum temperature of $280^{\circ} \mathrm{F}$ (RPP-10435 page A-42). After installation of airlift circulators, the operating temperature limit was revised to a maximum of $300^{\circ} \mathrm{F}$ at the tank bottom (RPP-10435 page A-54). Wastes at higher temperatures could cause buckling of the steel liner and/or structural damage to the concrete shell.

Beneath each of the tanks in the 241-A Tank Farm, three horizontal lateral pipes were installed in 1962 - 1963. These laterals were installed after waste leakage from tank 241SX-113 was suspected in 1958 and confirmed in 1962. Each lateral is approximately 10$\mathrm{ft}$ beneath the tank concrete foundation. These laterals are 4-inch outer diameter, 
schedule 40 seamless steel pipe. The horizontal lateral pipes enter a caisson, transition to vertical orientation, and extend to an instrument enclosure at ground elevation. Probes can be inserted into each lateral to monitor for gamma radiation that could indicate waste leakage from a tank or pipeline.

The 241-A tanks were vented to an underground vessel ventilation header that connected to 241-AX tank farm and later to the 241-AY tank farm. The purpose of this ventilation header was to remove offgas and water vapor from these tanks, which were often operated with the wastes at boiling conditions. Section 4.5.2 includes further discussion on the vessel ventilation header and analyses of samples of condensate collected from this system. The 241-A and 241-AX tanks were isolated from this ventilation header in the early 1980's.

Figure 4-2 Location of Drywells and Laterals in 241-A Farm

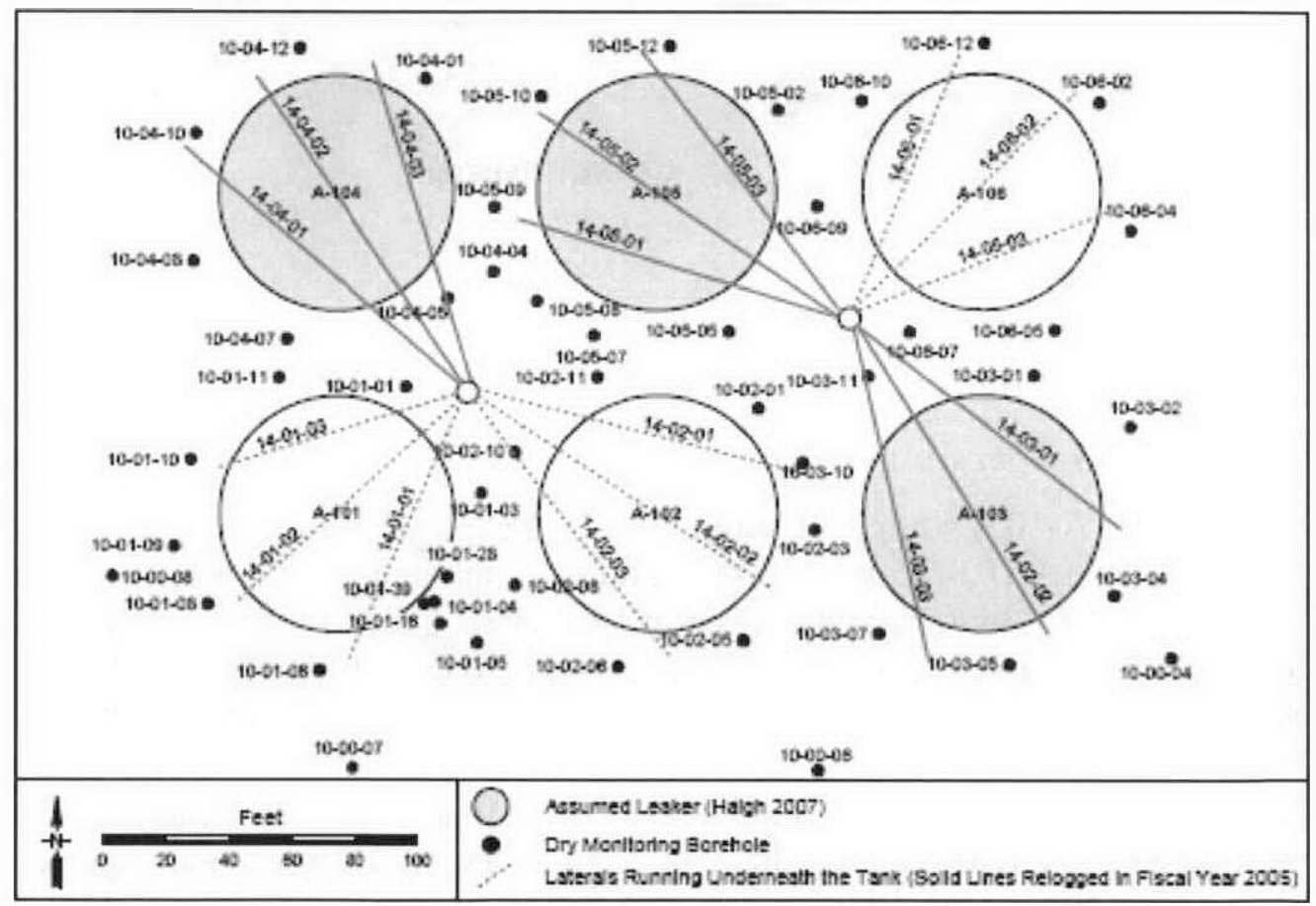

The design of this ventilation header included a baffled, 20 -inch diameter pipe inside each 241-A tank. The 20 -inch diameter pipe that exits the tank is connected to a 24 -inch diameter, stainless steel pipe header that is buried a minimum of 4 - $\mathrm{ft}$ below grade. The 24 -inch header ran between the tanks to the 241-A-431 ventilation building. Dresser couplings (see Figure 4-3) provide a compression seal on the outer surface of vapor header piping segments that are $\sim 25$ - $\mathrm{ft}$ in length. A Dresser coupling is also used to seal the 20 -inch diameter pipe from each tank to the 24 -inch main vapor header. The couplings provide for expansion and contraction of the vapor header pipe segments. 
Figure 4-3 Typical Dresser Coupling

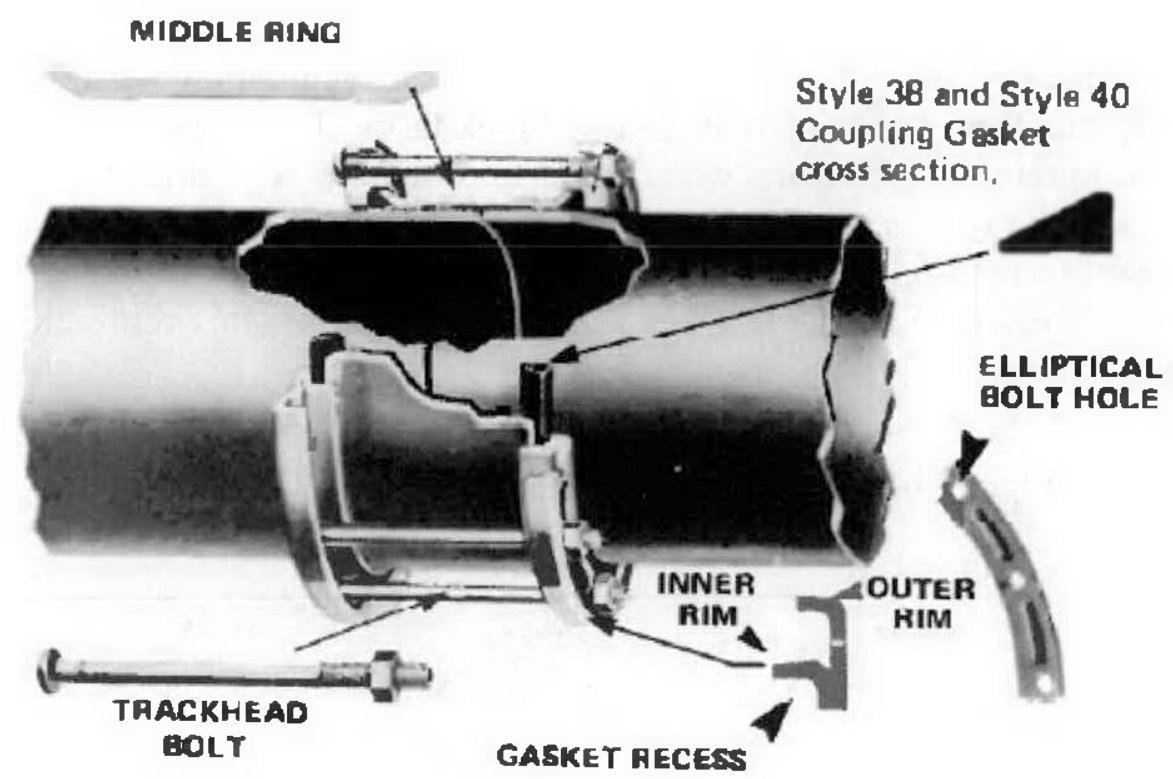

\subsection{Tank 241-A-103 Waste Loss Event}

\subsubsection{1-A-103 Operating Summary}

SST 241-A-103 (A-103) was constructed in 1955, but remained empty until May 1956. In May 1956, tank A-103 received 72,000 gallons of organic wash waste from the 202-A PUREX Plant (HW-43420 page 8). Then in June 1956, tank A-103 received 99,000 gallons of HLW supernate (P1 waste type) from the PUREX Plant (HW-43895 page 8). The waste temperature reached boiling $\left(102^{\circ} \mathrm{C}\right)$ on June 25,1956 (HW-44506 page 9).

Mild pressure surges were reported to have occurred in tank A-103 as early as July 1956 (HW-44580 page Fc-13), when boiling first started. Three consecutive bumps occurred in tank A-103 in September 1956, which blew the by-pass seal pot water seal (60 inches) and forced steam directly out the tank farm stack. The air-lift circulators were stated in the tank to prevent reoccurrence of this event (HW-45707 page J-7).

Tank A-103 continued to receive PUREX HLW, periodic additions of water and organic wash waste through July 1960 (HW-66557 page 8) to maintain the volume of selfconcentrating waste at approximately 500,000 gallons in this tank. No waste additions were reported for 1961 .

Approximately 330,000 gallons of PUREX HLW supernate were transferred from tank A-103 to tank A-105 in May1962 and additional 180,000 gallons were transferred in July 1962 (ARH-78 page 8). These transfers were made in order to demonstrate sludge 
sluicing capability in tank A-103. Water was then added to tank A-103 to soften the sludge and the sludge was sluiced to tank A-102 from March 1964 (HW-81620 page G-2) through November 17, 1964 (RL-SEP-112 page B-2).

Tank A-103 then received waste from the 244-CR vault, tank C-103, and PUREX organic wash waste in 1965 and 1966 . The supernate in tank A-103 was transferred to tank 101-A in March and April 1966 (ISO-75 page 53 and 70) to flush the tank. A new sluicer was installed in tank A-103 in May 1966 (ISO-75 page 85) and sluicing was again conducted intermittently between October 20, 1966 (ISO-75 page 174). and February 16, 1967 (ISO-651 page 30) to prepare tank A-103 to receive sludge slurry from tank A-105 sluicing. Following completion of sluicing, the sludge and supernate volumes in tank A-103 were reported as 0 and 55,000 respectively as of March 31, 1967 (ISO-806 page 8). The sludge volume was later revised in December 31, 1967 to 22,000 gallons (ARH326 page 9 ).

From February 1968 through November 1968, tank A-103 was used to receive the PUREX HLW supernate from tank A-105, subsequent flushes of tank A-105 with cesium denuded ion exchange waste, and sludge sluiced from tank A-105 (Interoffice Memo 7G420-06-004). Supernates collected in tank A-103 were periodically transferred to other single-shell tanks (e.g. AX-102, A-101, and A-102). Tank A-103 received sludge from a second sluicing campaign conducted in tank A-105 on July 31 - August 1, 1969 (ARH-1023-3-DEL pages 33-34) and August 25 - November 18, 1970 (Interoffice Memo 7G420-06-005), as described further in section 4.4.1.

The sludge slurry collected in tank A-103 from the second tank A-105 sluicing campaign was allowed to settle. Approximately 302,000 gallons of supernate were eventually transferred to tank C-105 in the second quarter of calendar year (CY) 1972, leaving 244,000 gallons of supernate and 102,000 gallons of sludge in tank A-103 (ARH-2456 B page 9). Supernates collected in tank C-105 were transferred to B Plant for cesium ion exchange processing.

Tank A-103 was next used in the second quarter of CY 1973 to receive $\sim 19,000$ gallons of sludge slurry from sluicing tank A-102 (ARH-2794 B page 9). Tank A-103 then received 71,000 gallons of waste from B Plant in the fourth quarter of CY 1973 (ARH2794 D page 9). Approximately 244,000 gallons of supernate were transferred from tank A-103 to tank A-104 in the first quarter of CY 1974, leaving 125,000 gallons of supernate and 102,000 gallons of sludge in tank A-103 (ARH-CD-133 A page 9). This later transfer was conducted to prepare for sluicing in tank A-103. The sludge in tank A103 was sluiced to 244-AR Vault beginning in the first quarter of CY 1974 (ARH-CD133 A page 9) and completed in September 1974 (SD-WM-TI-302 page 166).

Tank A-103 was used to collect PUREX Sludge Supernate (PSS) from various singleshell tanks and B Plant waste in the fourth quarter CY 1974 (ARH-CD-133 D page 9) through first quarter CY 1976 (ARH-CD-702 A page 9). The PSS waste was generated from washing sludges either in 244-AR Vault or in a single-shell tank, then decanting the supernates, which was identified as PSS waste. Approximately 920,000 gallons of 
supernate in tank A-103 were transferred to tank C-104 and 13,000 gallons were transferred to tank A-106 in the second quarter of CY 1976, leaving 20,000 gallons of supernate and 16,000 gallons of sludge in tank A-103 (ARH-CD-702 B page 9).

The removal of supernate from tank A-103 was in preparation for a final sluicing of the sludge in this tank. From October 13, 1976 (ARH-LD-222 B page 13) through early December 1976 (ARH-LD-224 B page 11) the sludge in tank A-103 was sluiced to tank A-106 (SD-WM-TI-302 page 166). This final sluicing in tank A-103 was conducted to prepare the tank to receive saltcake from operation of the 242-A Evaporator. Tank A-103 was reported to contain 2,080 gallons of sludge following completion of this last sluicing campaign (SD-WM-TI-302 page 166).

The 242-A Evaporator was operated using tank A-103 as a slurry receiver and feed tank from early 1977 through April 1980 (RHO-CD-80-1045 5 page 8). Tank A-103 received double-shell slurry feed (DSSF) and concentrated complexed (CC) waste during this period. Various reports of liquid level decline occurred in 1977 (IDMS Accession \#D194052856), 1978 (IDMS Accession \#D194035034), and 1979 (IDMS Accession \#D194053459), which were attributed the properties of the DSSF and CC wastes; namely foam, irregular waste surface, slurry growth and collapse (i.e. gas retention and release). No activity was detected in the three laterals and drywells associated with tank A-103 during these events, indicating no leakage of waste. After adding the last batch of DSSF to tank A-103 in March - April 1980 (RHO-CD-80-1045 5), there was a reported liquid level decrease from 193.4 inches (533,807 gallons) to 190.1 inches $(524,698$ gallons) in tank A-103 that occurred on September 4, 1980 over 11-hours (IDMS Accession \#D197183104). The cause of this liquid level decrease was attributed to mixing of dissimilar solids within the tank and a net volume decrease. In tank photographs revealed foam and floating yellow masses and a definite decline in liquid level. Tank temperature data indicated a mixing of the bottom and upper layers of solids within tank A-103.

Again, there was no activity detected in the laterals or the drywells, indicating tank A-103 was not leaking waste (IDMS Accession \#D196215974).

No further waste additions to tank A-103 occurred after these 242-A Evaporator campaigns. However, supernate was removed from tank A-103 as a result of a perceived tank leak, as discussed in section 4.2.2.

\subsubsection{Tank A-103 Waste Loss Estimate}

Tank A-103 was deactivated in August 1980 as part of the program to replace the older single-shell tanks with the newer double-shell tanks. Pumpable supernate was removed to reduce the supernate level. Active monitoring of the waste within tank A-103

continued, but no waste additions were allowed. Over a span of approximately 5.5 years (October 8, 1981 to March 5, 1987), the liquid level in tank A-103 was observed to have decreased from 187.5 inches $(517,520$ gallons) to 184 inches $(507,860$ gallons). As of

March 5, 1987, tank A-103 contained an estimated 8,800 gallons of supernate, 208,000 gallons of drainable interstitial liquid, and 499,000 gallons of solids. Since in-tank photographs showed the Food Instruments Corporation (FIC) plummet for measuring the 
waste surface was contacting liquid, this raised questions as to the integrity of this tank (EPDR 87-02).

An investigation into the integrity of tank A-103 was conducted in May 1987 by the tank farm contractor, following the procedures and rules for other tank integrity assessments documented in RHO-CD-1193 (Internal Letter 65000-WWS-87-033). A tank integrity assessment panel was formed consisting of the senior scientist and individuals representing process engineering, tank farms operations, health physics, and process technology. The tank A-103 integrity assessment panel reviewed information that supports the liquid level decline observed in tank A-103 was attributable to retained gas release. Core samples obtained from tank A-103 in April 1986 showed no interstitial liquid and were laced with air pockets or void spaces large enough to be clearly visible in photographs (IDMS Accession \# D196165963). Also slurry growth and collapse, resulting from gas retention and release, had also been observed in the waste stored in tank A-103. The liquid waste level in tank A-103 would slowly rise over a period of 9 to 12 months, then drop rapidly over one to two day period (Internal Letter 65950-87-291).

Three out of the five members of the 1987 tank integrity assessment panel stated at $95 \%$ confidence level that tank A-103 was sound, the liquid level fluctuations (both increases and decreases) were attributable to waste properties, and additional study of this phenomenon should be conducted. The other two panel members stated there was inconclusive evidence to relate the liquid level fluctuations to some waste phenomena. The assessment panel concluded tank A-103 should be classified as an assumed leaker, although there was no increase in activity detected in the laterals or drywells associated with this tank. The volume of waste leaked from tank A-103 was estimated as between 0 to 5,500 gallons, with the variability in the leak volume due to uncertainty whether the tank actually leaked (IDMS Accession \# D199126708). Pumping of interstitial liquid and supernate from tank A-103 was started on May 16, 1987 and completed on May 24, 1987. A total of 111,000 gallons of liquid waste were removed from tank A-103 to stabilize this tank (HNF-SD-RE-T1-178 page $15-18$ ).

The phenomenon of retained gas release has also been observed in other tanks (e.g. SY$101, \mathrm{SY}-103, \mathrm{AW}-101, \mathrm{AN}-103, \mathrm{AN}-104$, and AN-105) and is now referred to as buoyant displacement gas release events (BDGRF). During the 1990s, significant technical work was performed to understand the BDGRE behavior. The current tank farm safety basis relies upon a process developed from the culmination of this work to categorize waste tanks for BDGRE hazard. The process is described in Methodology and Calculations for the Assignment of Waste Groups for the Large Underground Waste Storage Tanks at the Hanford Site (RPP-10006). However, the BDGRE process and mechanisms were not understood in 1987 when the integrity investigation for tank A-103 was conducted. Therefore, a mechanism does exist that could explain the liquid level fluctuations observed in tank A-103. The 1987 tank integrity assessment panel's recommendation to classify this tank as an assumed leaker may have been incorrect.

Spectral gamma data for several drywells (10-03-01, 10-03-05, 10-03-07, 10-02-03, and $10-03-11$ ) around tank A-103 measure small amounts of $\mathrm{Cs}^{137}$ (about $0.1 \mathrm{pCi} / \mathrm{g}$ ) at $80 \mathrm{ft}$ 
bgs and below, which is thought to be associated with drag-down of contamination when the well depths were extended (RPP-35484 page 2-11). Gross gamma logging of the laterals beneath tank A-103 was conducted in March 2005 and also shows only small amounts of $\mathrm{Cs}^{137}$ (less than $10 \mathrm{pCi} / \mathrm{g}$ ) beneath the tank (RPP-RPT-27605 pages B-4 thru B-9). The gamma loggings do not shown any evidence of waste loss from tank A-103. The interstitial liquid in tank A-103 was sampled in April 1986 and results for $\mathrm{Cs}^{137}$ were an average of $3.97 \mathrm{E}+05 \mu \mathrm{Ci} / \mathrm{ml}$ (SD-WM-TI-198). If tank A-103 had leaked 5,500 gallons, then about 8,260 $\mathrm{Ci}$ of $\mathrm{Cs}^{137}$ (as of April 1986) would have leaked to the soil. The gamma loggings do not shown any evidence of waste loss from tank A-103 and certainly not this level of $\mathrm{Cs}^{137}$ in the laterals or drywells.

Another notable liquid level decline in tank A-103 was reported on November 16, 1987. The liquid level declined from a reference of 143.4 inches to 140.6 inches during a three day period. However, the FIC liquid level monitor readings fluctuated up and down between 143 inches to 140.6 inches during this time frame (Vermeulen 1987). Inspection of photographs taken inside tank A-103 on December 28,1988 showed that the FIC plummet was contacting dry solids in a deep depression of multiple elevations, leading to erratic readings (Baumhardt 1989). Therefore, no waste loss from tank A-103 is associated with this event.

\subsubsection{A-103 Conclusions}

The assessment team members concluded that based on available information, there is no evidence tank A-103 lost containment and no leak volume or inventory was assigned to this tank.

\subsection{Tank 241-A-104 Waste Loss Event}

\subsubsection{1-A-104 Operating Summary}

SST 241-A-104 (A-104) was constructed in 1955, but remained empty until 1957. In June 1957, 17,000 gallons of "test water" were added to the tank (HW-51348 page 8). The purpose of this test water and the source were not located in available records. The monthly waste status summary reports recorded the volume of test water in SST A-104 varied from 17,000 gallons to 36,000 gallons from June 1957 through July 1958 . No explanation was located in the available records for the reported changes in the test water volume in SST A-104, but the variations could be due to calibrating instruments, addition of test water to the tank, or testing transfer systems.

In August 1958, SST A-104 received 20,000 gallons of HLW supernate (P1 waste type) from the 202-A PUREX Plant (HW-57550 page 8). Self concentration of waste in SST A-104 was reported to have started in August 1959 (HW-61952 page 8), which enabled additional P1 waste to be periodically transferred into SST A-104 from January 1959 through December 1961. Organic wash waste (OWW) from the PUREX Plant was also reported to have been transferred to SST A-104 during 1960 through March 1968 (IDMS Accession \#D197260431 and ARH-534 page 9). The OWW was self concentrated (i.e. evaporated) in the tank. The peak temperature reported for SST A-104 was $225^{\circ} \mathrm{C}$ 
$\left(437^{\circ} \mathrm{F}\right)$ on February 16,1963 , but was quickly reduced to below $340^{\circ} \mathrm{F}$ by adding OWW to the tank to increase liquid level (IDMS Accession \#D197260431 and RHO-CD-1172 page B-4). The waste volume in tank A-104 was generally maintained at less than 980,000 gallons during self concentration of wastes.

In the first and second quarters of 1969, a total of 669,000 gallons of the OWW / P1 supernate was transferred from SST A-104 to SST C-105 (ARH-1200 A page 10 and ARH-1200 B page 10), leaving approximately 171,000 gallons of solids and 69,000 gallons of supernate in SST A-104. Sluicing of the solids from tank A-104 to tank A-106 was conducted from May 12, 1969 (ARH-1200 B page 10) through October 1969 (ARH$1200 \mathrm{D}$ page 10). An estimated 3,000 gallons of solids remained in SST A-104 following sluicing. The tank was refilled with 957,000 gallons of water for a leak test to confirm integrity and the tank was declared a spare (ARH-1200 D page 10). The supernate temperature in SST A-104 was reported as approximately $120^{\circ} \mathrm{F}$ following refilling the tank with water (RHO-CD-1172 page B-14). No additional temperature data for SST A-104 was found for the period of December 1969 through August 1974.

No waste transfer activity was reported again for SST A-104 until 1972. However, the supernate volume in SST A-104 decreased from 957,000 gallons in October 1969 to approximately 259,000 gallons in January 1972 (ARH-2456 A page 9). A tube bundle heat exchanger $(200,000 \mathrm{Btu} / \mathrm{hr}$ ) was reported to be installed in SST A-104 (drawing H2-35091) and removed in September 1974 (IDMS Accession \#D194052941), which may explain the liquid level decrease.

Approximately 132,000 gallons of water was transferred from SST A-104 in the first and second quarters of calendar year 1972 (ARH-2456 A page 9 and ARH-2456 B page 9). Then, SST A-104 was used to receive PUREX Sludge Supernate (PSS waste type) from 244-AR Vault from the third quarter of calendar year 1972 (ARH-2456 C page 9) through the second quarter of calendar year 1974 (ARH-CD-133 B page 9). SST A-104 also received B Plant strontium solvent extraction waste (waste type B) in the fourth quarter of calendar year 1972 (ARH-2456 D page 9, first quarter of 1974 (ARH-CD-133 A page 9), and water from SST A-103 in first quarter of 1974. Excess supernate was periodically transferred to other SST in 241-AX tank farm.

The PSS waste type contained PUREX sludge solids that did not rapidly settle in the relatively small tank 004 in 244-AR Vault and were transferred to the much larger SST A-104 for settling. A total of approximately 80,000 gallons of PUREX sludge solids and 726,000 gallons of PSS were present in SST A-104 in third quarter of calendar year 1974 (ARH-CD-133 B page 9).

Sluicing of the accumulated solids in SST A-104 to the 244-AR Vault was started in September 1974 and was halted April 7, 1975, due to an increase in the radiation detected in lateral no. 2 beneath the tank. The location of the peak activity detected in lateral no. 2 (center lateral) was "... approximately 18 -ft in from the northwest edge of the tank" and "... On swing shift of April 8, 1975, a second radiation peak was observed in the same lateral and an adjacent lateral [lateral no. 1], located, located approximately 13 feet in 
from the southeast edge of the tank" (IDMS Accession \#D194052989 page 27). Gross gamma scans of drywells 10-04-01, 10-04-04, 10-04-05, 10-04-07, 10-04-08, 10-04-10, and 10-04-12 did not indicate activity about background. The locations and dates of high peak gamma activity readings in the laterals are shown in Figure 4-4 (ARH-LD-120 page 123). SST A-104 contained 65,000 gallons of waste, including an estimated 25,000 gallons of sludge when the activity was detected in the laterals. Approximately 46,700 gallons of supernate were pumped from tank A-104 from April 9 thru April 19, 1975 to remove the supernate (IDMS Accession \#D194052989).

Figure 4-4 Location of Peak Readings in Tank A-104 Laterals

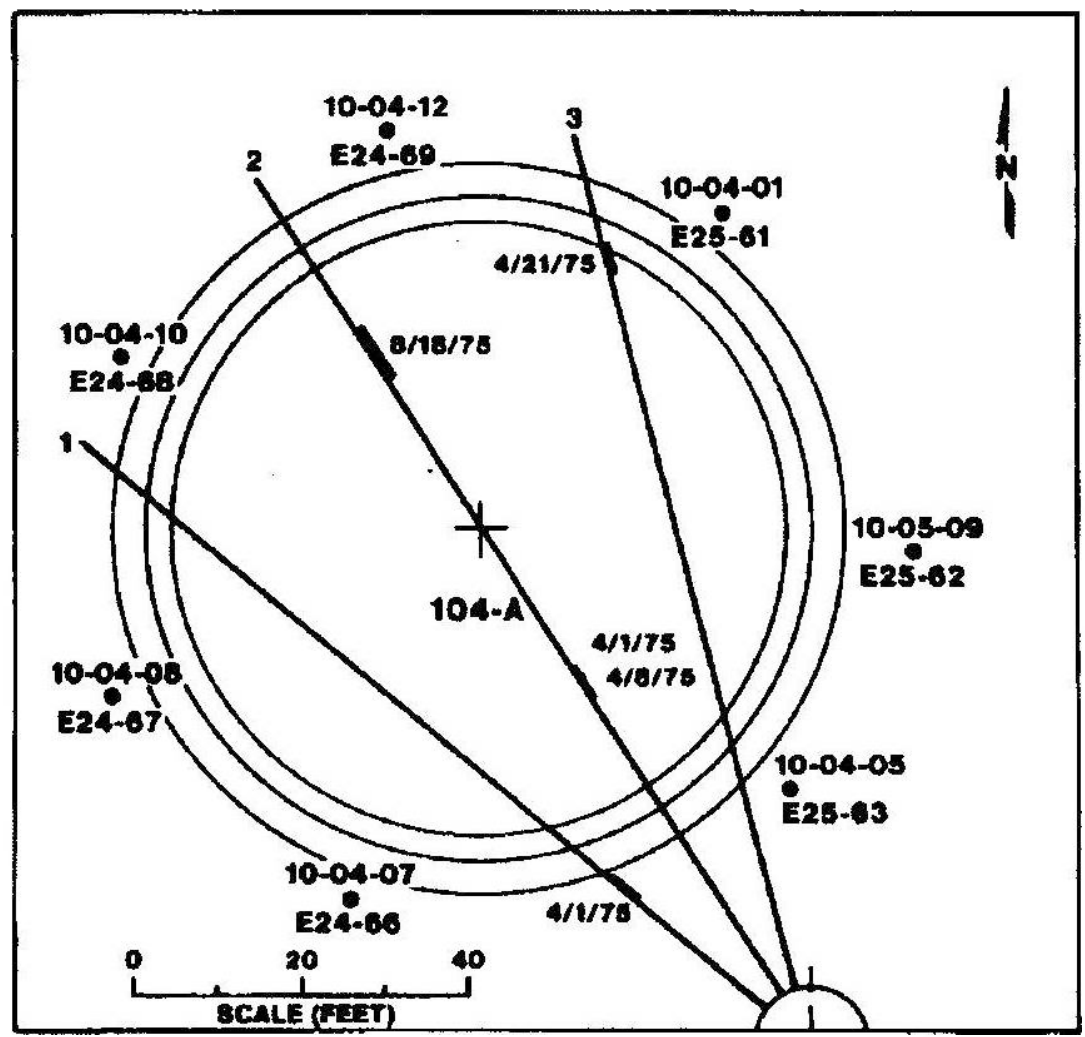

Gross gamma logging of lateral 14-04-01 (lateral no. 1) and 14-04-02 (lateral no. 2), shown in Figure 4-5 and Figure 4-6, were conducted in April 2005 to access the extent of contamination present beneath tank A-104 (RPP-RPT-27605 pages B-11 and B-13).

The historical gross gamma profiles for laterals 14-04-01, 14-04-02, and 14-04-03 (RPP35484 page 3-91) indicate that the contaminant or contaminants emitting this radiation were relatively short-lived (e.g., ruthenium-106, cerium-144). The April 2005 surveys on laterals 14-04-01 and 14-04-02 registered no zones of elevated radiation levels. Currently, few radionuclides are still measurable (e.g., $\mathrm{Cs}^{137}, \mathrm{Co}^{60}$ ). RPP-35484 page 391 concludes "The lack of cesium-137 at the laterals may indicate a substantially smaller 
leak than the ones at tank A-105, if the waste stream compositions were similar. Alternately, the waste present in tank A-104 may have contained a less cesium-137 rich waste stream in 1975".

Figure 4-5 Gamma Survey for I ateral 14-04-01L

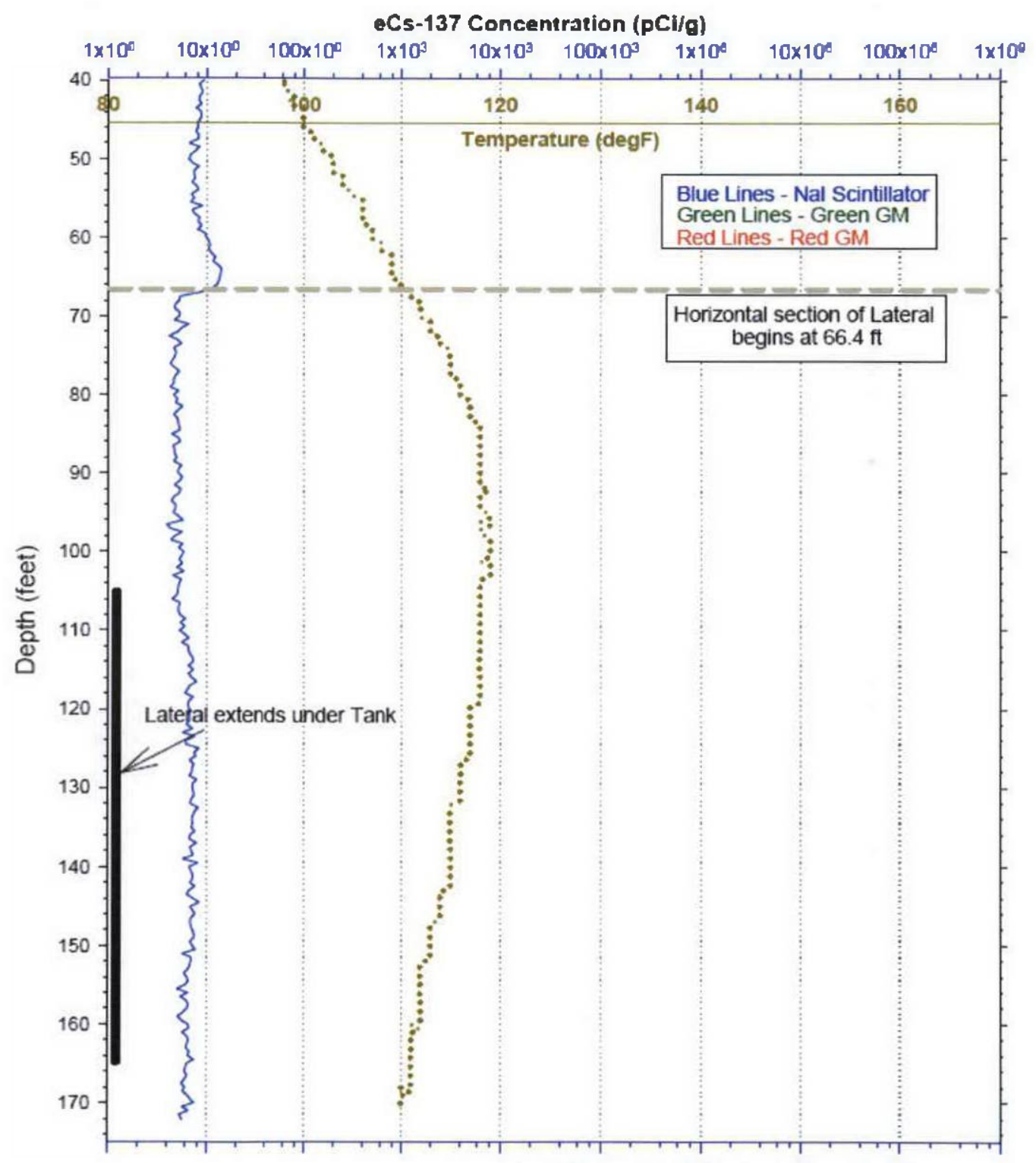

Log date: April 2005. Reference depth: ground level. 
Figure 4-6 Gamma Survey for Lateral 14-04-02L

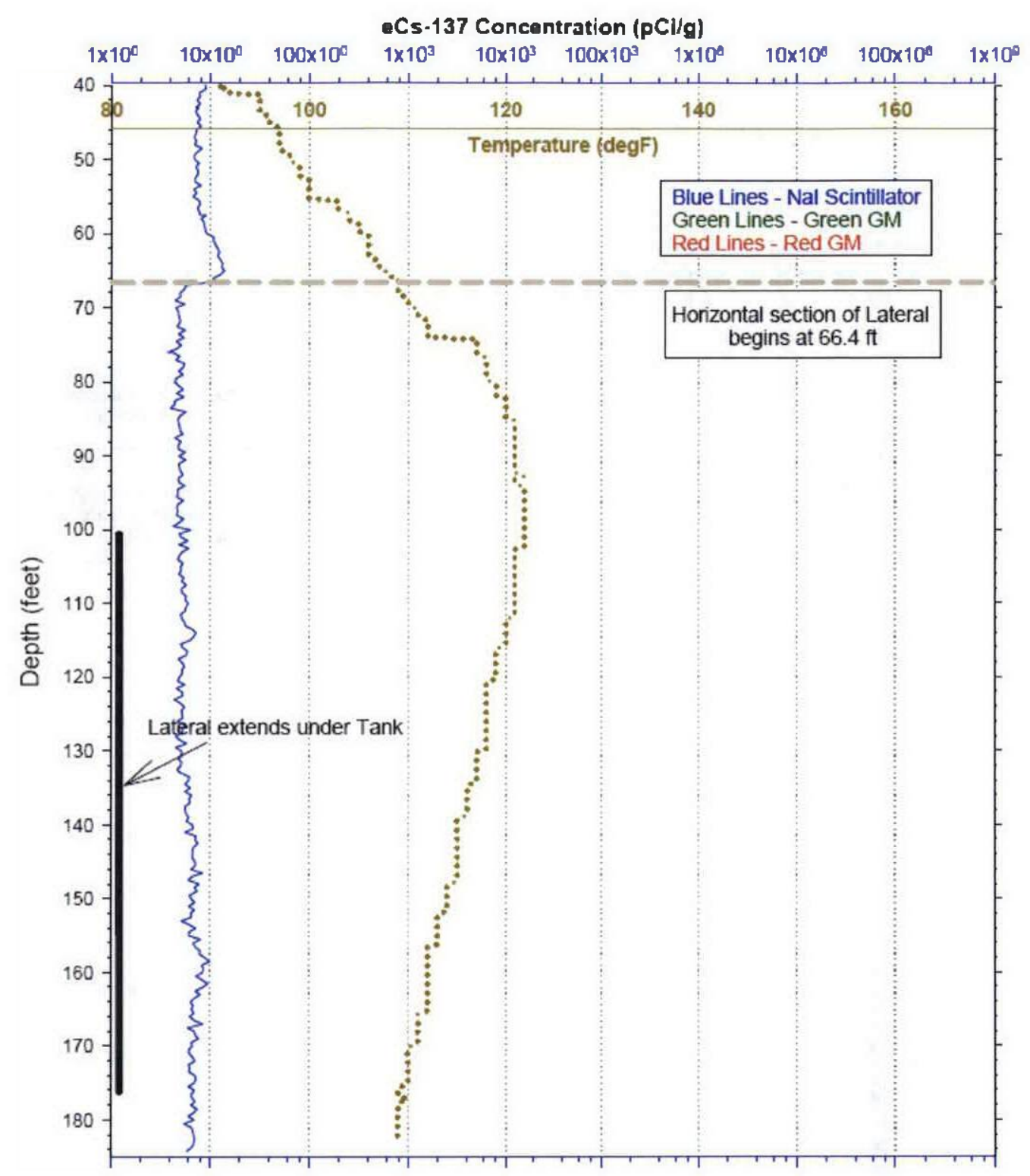

Log date: April 2005. Reference depth: ground level.

\subsubsection{Tank A-104 Waste Loss Estimate}

HNF-EP-0182, rev. 237, Waste Status Summary Report for Month Ending December 31, 2007, estimates between 500 to 2,500 gallons of waste was loss from SST A-104 in 1978. The basis for this estimate is cited as PNL-4688, Assessment of Single-Shell Tank Residual Liquid Issues. Section 3.1.3.1 of PNL-4688 discusses past leaks from SSTs as of May 1982 and provides a table summarizing estimated leak volume by each tank. PNL-4688 references RHO-RE-SR-14-May 1982, Waste Status Summary May 1982, as 
the source identifying leaking SSTs and states the estimated waste leaked from SST A-104 is 2,500 gallons. RHO-RE-SR-14-May 1982 identifies SSTs that were categorized as having leaked waste, but does NOT list the volume of waste leaked from any of these SSTs. PNL-4688 provides no other basis for the estimated waste loss from SST A-104.

The first time estimates for waste losses from SSTs appear in a monthly waste status summary report is in September 1983 (RHO-RE-SR-14-September 1983 page 28). The reported estimated waste loss from SST A-104 is less than 1,500 gallons. The estimated waste loss from SST A-104 reported in RHO-RE-SR-14-September 1983 is consistent with the estimated waste loss of 700 to 1,500 gallons reported in July 1975 by the Hanford site contractor in correspondence with the U.S. Energy Research and Development Administration (Burton 1975). Furthermore, the tank farm contractor's monthly report for June 1975 also reports the estimated waste loss from SST A-104 as 700 to 1,500 gallons containing 840 to 1,800 curies of $\mathrm{Cs}^{137}$ (ARH-LD-206 B page 10). This equates to $1.2 \mathrm{Ci} / \mathrm{gal} \mathrm{Cs}^{137}$ as of June 1975 or $0.56 \mathrm{Ci} / \mathrm{gal}$ as of May 2008 .

In September 1975 Atlantic Richfield Hanford Company (tank farm contractor) conducted a study at tank 104-A to re-evaluate the leak size and note the behavior of the leak plume with respect to the subsurface geology. A series of isotopic and directional gamma readings were taken in three horizontal monitoring laterals three meters below tank A-104 at the time of the leak and again about three months after the leak was confirmed. "From the initial readings, conclusions based on the initial data are: (1) The leak plumes were in the shape of hemiprolate spheroids; the predominant isotope was ${ }^{106} \mathrm{Ru}$ with trace elements ${ }^{137} \mathrm{Cs}$ and ${ }^{60} \mathrm{Co}$; and the ${ }^{106} \mathrm{Ru}$ concentration profile and shape of the leak plumes established the size of the leak to be approximately 2,000 gallons" (ARH-I.D-209 B page 34).

The tank farm contractor's monthly report for June 1975 indicates all pumpable liquid was removed from SST A-104 and an exhauster connected to remove all remaining liquid via evaporation (ARH-L.D-206 B page 10). ARHCO reported in July 1975 that an estimated 7,000 gallons of liquid was removed from SST A-104 as a result of operation of the connected exhauster (Burton 1975). Photographs of the tank interior taken on May 29,1975 were reported to show approximately 9 inches of sludge, "... no evidence of any surface liquid and the exposed sludge appears to be severely checked which indicates a dry condition" (ARH-LD-206 B page 10). Additional photographs of the interior of SST A-104 were obtained on June 25,1975 . These photographs " $\ldots$ indicate the sludge is definitely drying (no visible pools of liquid and a surface of cracked solids) due to operation of a portable exhauster" (ARH-I.D-207 B page 10).

\subsubsection{A-104 Conclusions}

Based on the information above, it appears the estimated waste loss from SST A-104 reported in PNL-4688 and HNF-EP-0182, rev. 238 (i.e. 500 to 2,500 gallons) is incorrect. The estimated waste loss from SST A-104 should be $\sim 2,000$ gallons. The waste type leaked from tank A-104 is PUREX Sludge Supernate (PSS), containing $\sim 0.56 \mathrm{Ci} / \mathrm{gal}$ $\mathrm{Cs}^{137}$ as of May 2008. The waste type and estimated leak volumes are consistent with 
those used in RPP-26744, Soil Inventory Model Rev. 1 and the field investigation analysis in RPP-35484.

\subsection{Tank 241-A-105 Waste Loss Event}

\subsubsection{1-A-105 Operating Summary}

The operational history for tank A-105 is summarized from Interoffice Memo 7G420-06004, Interoffice Memo 7G420-06-005, and DOE/ORP-2008-01. The reader is referred to these references for further details.

Tank A-105 initially sat unused from finish of construction in 1957 until May 1962. Aged $^{2}$ PUREX HLW supernate was first added to this tank from tank A-103 in May 1962. Additional aged PUREX HLW supernate was added to tank A-105 from tank A-102 in December 1962. Then the contents of tank A-105 were pumped to tanks C-103 and A-101 in January 1963, leaving a 10-inch ( $-27,600$ gallons) heel of waste in tank A-105. Thermally hot condensate was added to tank A-105 to heat the tank in preparation to receive HLW from the 202-A PIJEX Plant.

Beginning in February 1963, tank A-105 began to receive HLW directly from the 202-A PUREX Plant. The PUREX HLW contained significant concentrations of fission products that resulted in the waste self-boiling. As space became available in tank A-105 as a result of waste evaporation, periodic transfers of PUREX HLW were received until January 1965 , at which time it contained 866,000 gallons of waste. The maximum reported waste temperature in tank A- 105 was approximately $320^{\circ} \mathrm{F}$ in March 1963 , but generally was controlled to $180^{\circ} \mathrm{F}$ to $260^{\circ} \mathrm{F}$ from February 1963 thru March 1965 (RHOCD-1173 pages B-39 thru B-45). On November 19, 1963, there are indications that this tank developed a small leak due to radioactivity detected in lateral 14-05-03 (ARH-78). Additional waste likely leaked from this tank during a steam expulsion event that occurred on January 28, 1965 (ARH-78).

On January 28, 1965, tank A-105 experienced a rapid pressurization event that resulted in the tank liner bulging upward. Radioactivity $(250,000$ to $350,000 \mathrm{c} / \mathrm{m})$ was detected in March 1965 in a small area of lateral no. 3 beneath the tank. The activity detected in lateral no. 3 did not significantly change from March 1965 through January 1968. The tank liquid level was maintained between 850,000 to 887,000 gallons through January 1968 by addition of water. As discussed in WHC-MR-0264, radioactivity was also detected in lateral no. 2 beneath tank A-105 in October 1967.

From February 1968 through August 1968, the supernate in tank A-105 was removed and the supernate heel diluted through a series of flushes using B Plant cesium ion exchange supernate (waste type CSR as defined in RPP-26744) in preparation for sluicing the sludge in this tank (Interoffice Memo 7G420-06-004). The $\mathrm{Cs}^{137}$ concentration in the CSR supcrnate used to flush the HLW supernate in tank A-105 was an average of

\footnotetext{
${ }^{2}$ The term "aged" means the short half-life radionuclides had decayed sufficiently that the waste was no longer self-boiling.
} 
$0.58 \mathrm{Ci} / \mathrm{gal}$, decay corrected to January 2006 (Interoffice Memo 7G420-06-004). The tank A-105 flush solution was transferred to tank A-103, then tank AX-102 and finally to B Plant for cesium removal processing.

Following the dilution and flushing of tank A-105 supernate, two sluicing campaigns were conducted to remove the sludge from tank 241-A-105. The first sluicing campaign, conducted from August through November 1968, used cesium denuded supernatant derived from operation of the cesium ion exchange process in the 221-B Plant (Interoffice Memo 7G420-06-004). The $\mathrm{Cs}^{137}$ concentration of the sluicing fluid was estimated to be $0.53 \mathrm{Ci} / \mathrm{gal}$ to $0.58 \mathrm{Ci} / \mathrm{gal}$ (decay corrected to January 2006). Sluicing of tank $241-\mathrm{A}-105$ sludge was halted when little of the remaining sludge could be removed. A hard crust layer atop the remaining sludge was thought to be responsible for preventing effective sluicing. Approximately half of the sludge was removed during this first sluicing campaign.

In the second sluicing campaign, $1 \mathrm{M}$ sulfuric acid, containing 1500-ppm of the inhibitor, Rhodine $A^{3}$, were sprayed onto the top layer of hard sludge in Tank A-105 (Interoffice Memo 7G420-06-005). Cesium denuded supernatant, generated in the 221-B Plant and contained in tank 241-A-103, was used as the sluicing fluid. The sludge sluiced from tank 241-A-105 was transferred into tank 241-A-103. No additional sludge removal activities in tank 241-A-105 were conducted until August 25, 1970. Inhibited sulfuric acid was again used in August 25, 1970 to soften the sludge in tank 241-A-105. The softened sludge was then sluiced using cesium denuded supernatant contained in Tank 241-A-103. The sludge slurry was transferred from Tank 241-A-105 to Tank 241-A-103. Following the completion of this phase of the sludge removal from Tank 241-A-105, approximately 33,000 gallons of supernatant and 33,000 gallons of sludge were reported to remain within this tank. The supernatant contained in Tank 241-A-105 was described as being a mixture of B Plant cesium ion exchange waste (i.e. cesium denuded ion exchange waste) and PUREX high-level waste.

The cesium denuded supernatant used to sluice the sludge from Tank 241-A-105 to Tank 241-A-103 was derived from cesium ion exchange processing conducted in 221-B Plant. Sluicing conducted in July - August 1969, used the same cesium denuded supernatant solution as was used during the first Tank 241-A-105 sluicing campaign. However, Tank 241-A-105 sluicing conducted in August - November 1970 used a different source of cesium denuded supernatant. The estimated concentration of the cesium denuded supernatant used to conduct sluicing of Tank 241-A-105 sludge to Tank 241-A-103 from August - November 1970 is $0.51 \mathrm{Ci} /$ gal, decayed to January 2006 (Interoffice Memo 7G420-06-005).

In 1977, photographs taken inside tank A-105 in 1969, 1970, and 1977 were reviewed to determine the amount of sludge remaining in the tank as well as develop a topographical map of the tank bottom (IDMS Accession \#292-000583). The topographical map of the tank bottom produced in 1977 is shown in Figure 4-7. This topographical map clcarly shows the bottom of the steel liner in tank A-105 is ripped and separated from the sidewall along approximately $3 / 4$ of the tank bottom.

\footnotetext{
${ }^{3}$ Trade name of Amchem Products Corporation
} 


\section{RPP-ENV-37956 Rev. 1}

Figure 4-7 Topographical Map of Tank A-105 Bottom (1977)

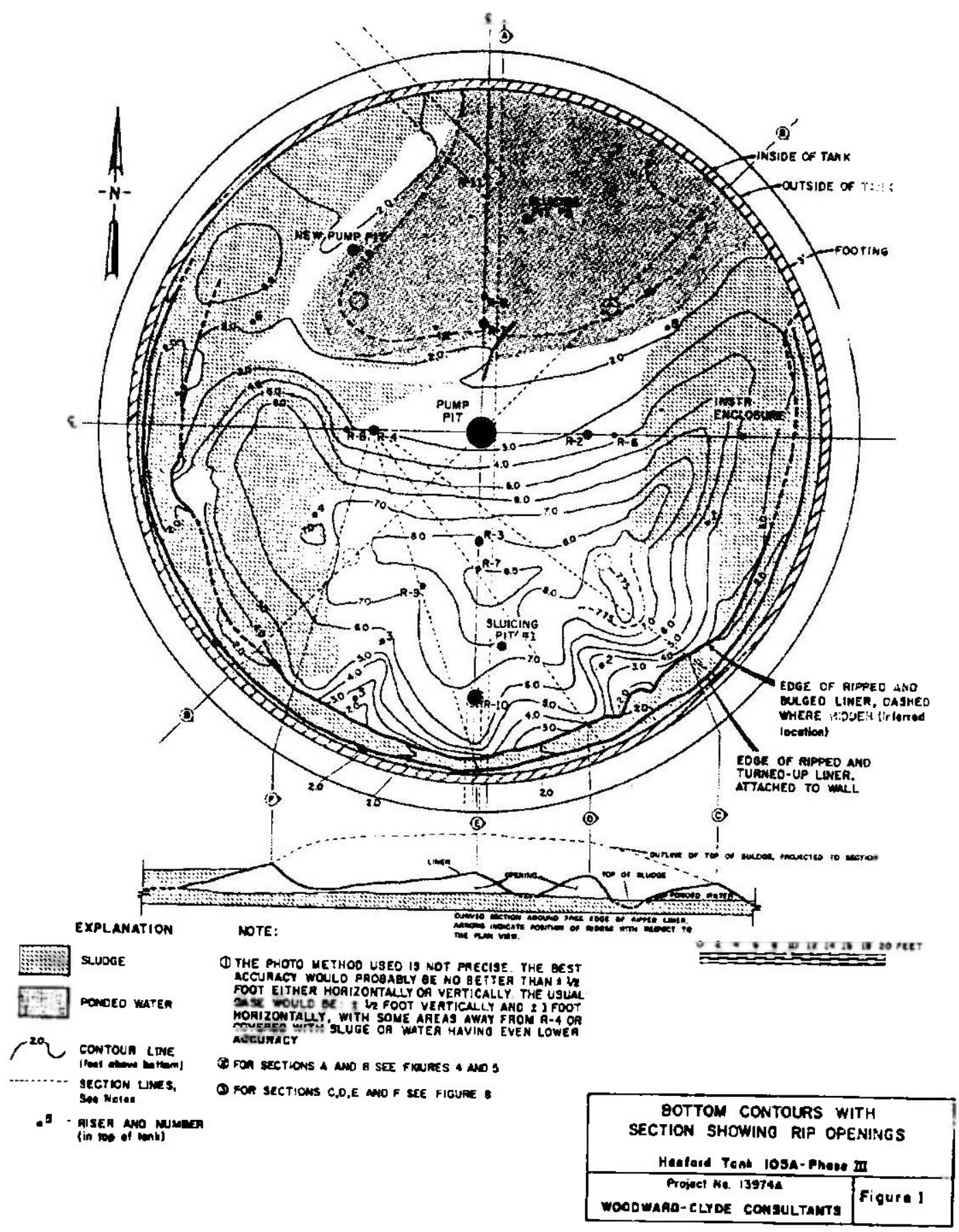


Following the sluicing of the waste, water was periodically added to tank A-105 from November 1970 through December 1978 for evaporative cooling of the remaining sludge. An estimated 610,000 gallons of water was added to tank A-105 for cooling and flushing of the airlift circulators (WHC-MR-0264 page 22). The estimated amount of water evaporated from tank A-105 from November 1970 through December 1978 is 378,000 to 410,000 gallons (WHC-EP-410). Therefore, an estimated 200,000 to 232,000 gallons of water are unaccounted for and may have leaked from tank A-105.

\subsubsection{Nature and Extent of Contamination at Tank A-105}

RPP-35484, Field Investigation Report for Waste Management Areas $C$ and $A-A X$ (DOE/ORP-2008-01) provides an extensive review of field investigations conducted to characterize the contamination beneath tank A-105. A summary of the findings from RPP-35484 are provided in this section.

The laterals beneath tank A-105 are shown in Figure 4-8. Gross gamma loggings of the three laterals beneath tank A-105 were conducted in April 2005 (RPP-RPT-27605 pages B-15, B-17 and B-19). The logs for laterals underneath tank A-105 show increased gamma activity along laterals $14-05-02 \mathrm{~L}$ and 14-02-03L (Figure 4-9). These laterals interrogate the central portion (14-05-02I) and northeastern quadrant (14-05-03L) of the tank. The most extensive $\mathrm{Cs}^{137}$ contamination was found to be associated with lateral 14-05-03, where cesium activity is estimated to be as high as $3.4 \times 10^{7} \mathrm{pCi} / \mathrm{g}$ near the distal end of that lateral.

These gamma logs indicate that the vast majority of the waste loss from tank A-105 is associated with the regions near the perimeter of the tank, where drywell logs would have the optimal opportunity to detect the contaminants. Elevated $\mathrm{Cs}^{137}$ does not extend beyond $10 \mathrm{ft}$ horizontally from the regions of peak intensity before declining to near background levels. The nearest drywells to these locations are 10-06-09 and 10-05-12, which are beyond that distance. Gamma logs of these drywells are shown in Figure 4-10 and Figure 4-11. Neither the lateral set of logs nor the drywell set of logs indicate a major release of mobile gamma-emitting radionuclides. 
Figure 4-8 Location of Laterals for Tank 241-A-105

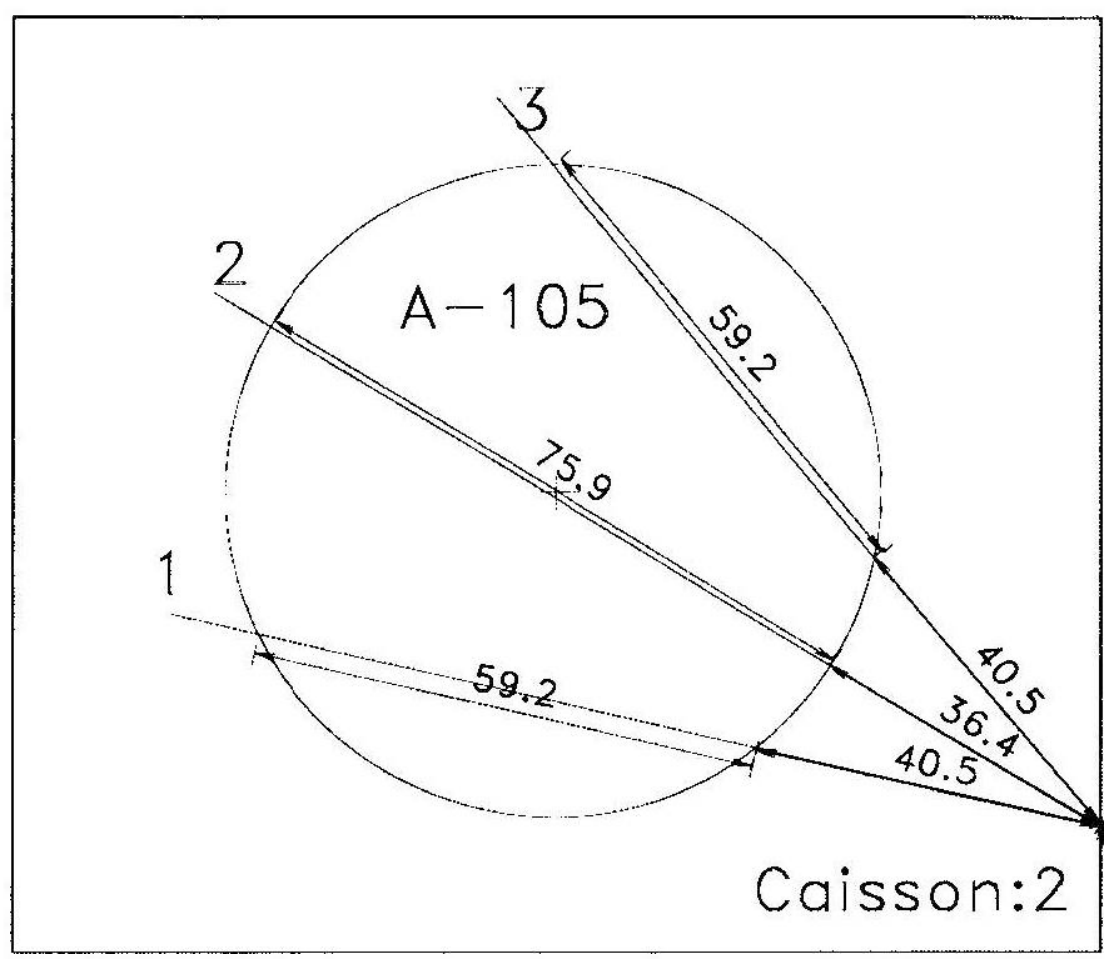

The numbers 1, 2, and 3 indicate laterals 14-05-01, 14-05-02 and 14-05-03, respectively. The other numbers indicate the horizontal lengths of the lateral from the caisson (e.g., 40.5 at lateral 3) or underneath the tank (e.g. 59.2 at lateral 3). 
Figure 4-9 Summary Gamma Survey for the Laterals under Tank A-105
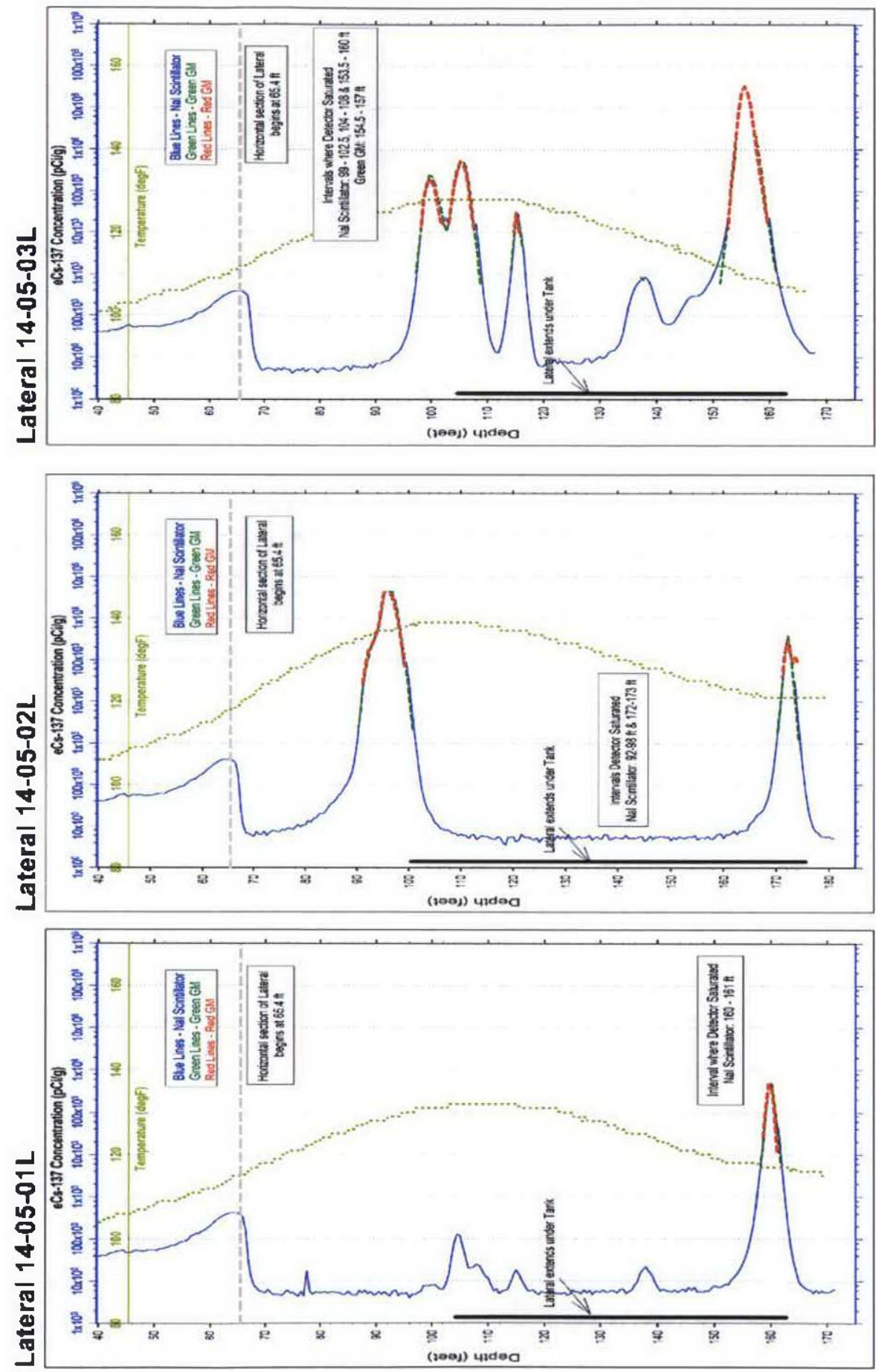
RPP-ENV-37956 Rev. 1

Figure 4-10 Spectral Gamma Log of Drywell 10-06-09

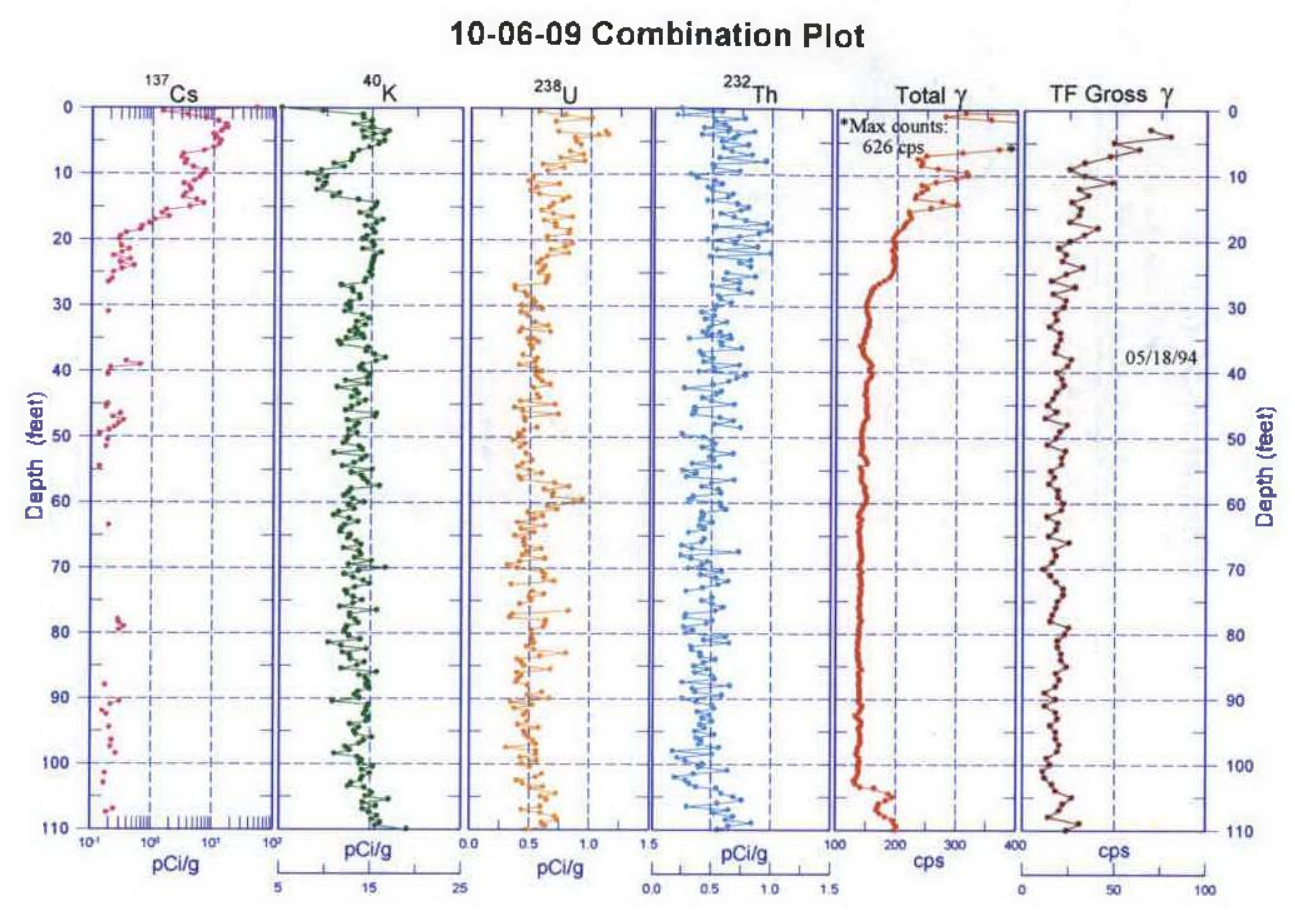




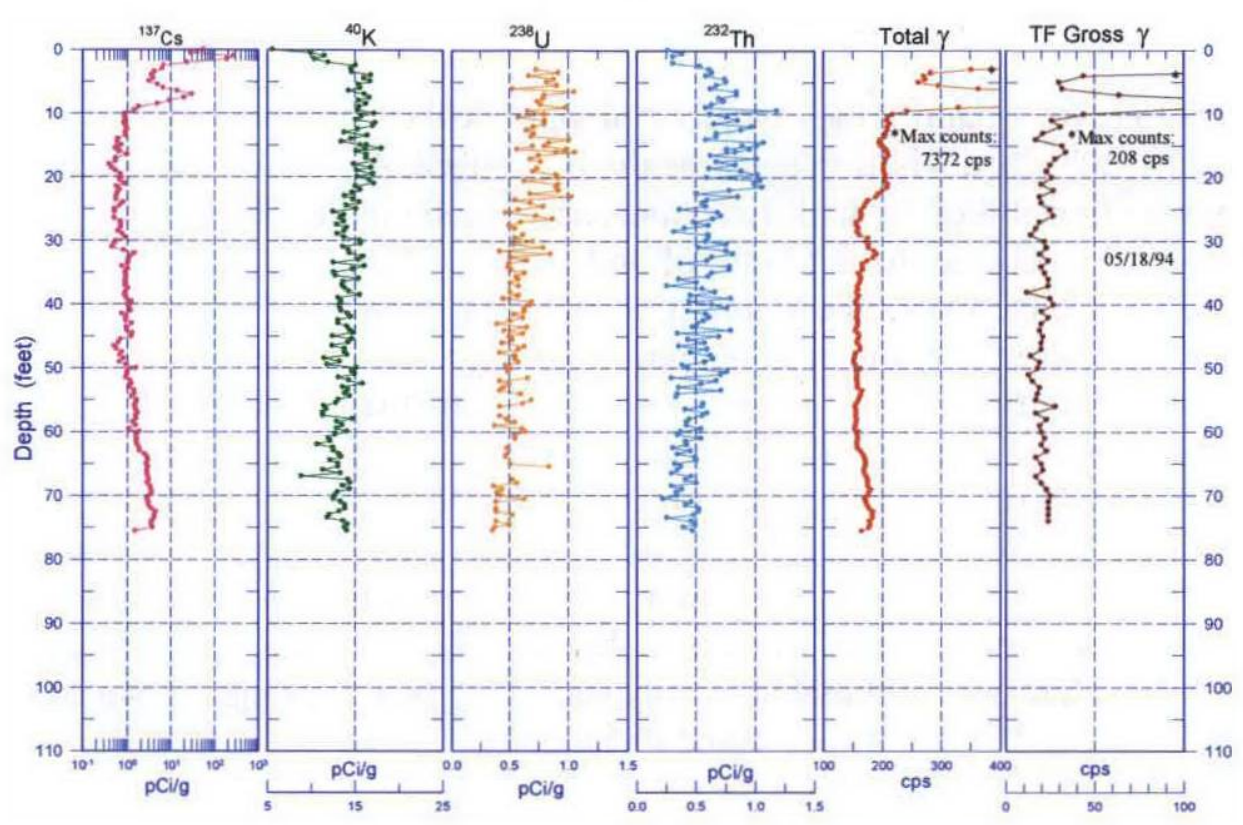

\subsubsection{Tank A-105 Waste Loss Estimate}

Historically, a volume estimate range of 5,000 to 15,000 gallons was proposed for this leak by Jansen et al. (1965) depending on the location of the contaminated soil volume with respect to the hot spot on lateral 14-05-03. However, the physical model used as the basis for this estimate was devised to facilitate the modeling analysis and did not represent important conditions affecting contaminant behavior. Therefore, it is not surprising that the estimated leak volume range needed to create the observed temperature profiles using these assumptions is implausible. Some of the implausible assumptions were steady state thermal conditions, heat generation caused solely by $\mathrm{Cs}^{1.97}$ decay, a maximum temperature of $260^{\circ} \mathrm{F}$ in the elevated temperature zone and complete saturation of a hemispheroidal volume of vadose zone sediment underneath the tank before evaporation occurs. Heat dissipation was highly transient in $1965, \mathrm{Cs}^{137}$ was not the dominant heat producer affecting the elevated temperature zone early on, and the maximum temperature exceeded $300^{\circ} \mathrm{F}$. The concept of saturated flow in the vadose zone is contradicted by numerous field observations. For example, field injection experiments designed and implemented to simulate a small leak tracked moisture content in the vadose zone near an injection point. These experiments have shown that excess fluid quickly distributes in the subsurface to restore ambient sediment moisture contents and that this distribution occurs primarily under unsaturated conditions.

Given the modeling analysis configuration, Jansen et al (1965) estimated that a minimum leak volume of 6,000 gallons was needed to generate the highest elevated temperature in 
lateral 14-05-03. This corresponds to a $\mathrm{Cs}^{137}$ loss of about $184,000 \mathrm{Ci}$ which is a gross overestimate of actual vadose zone contamination. To put this value in perspective, $\mathrm{Cs}^{137}$ losses from the 115,000 gallon T-106 tank leak are about $11,000 \mathrm{Ci}$ and $\mathrm{Cs}^{137}$ was measured in numerous drywells around that tank. Clearly, a significantly smaller volume of waste was discharged in the 1965 event.

In an effort to better quantify the inventory of waste leaked from tank A-105, a new conceptual model was devised to describe the leak. Tank A-105 was assumed to have leaked over an area 3/4 of the tank circumference, based on the topographical mapping of the tank bottom discussed in Section 4.4.1 and shown in Figure 4-7. The waste is assumed to have leaked from the tank to the laterals, a distance of $10-\mathrm{ft}$ and spread the same width as indicated by the gross gamma analyses for the three laterals (see Figure 4-9). The concentration of $\mathrm{Cs}^{137}$ in the soil contacted by the leaked waste is assumed to be at the maximum cesium sorption capacity of $4.0 \mathrm{E}+07 \mathrm{pCi} / \mathrm{g}$. The estimated waste loss was then calculated for two cases: 1) assuming PUREX HLW supernate was leaked and 2) assuming B Plant ion exchange waste was leaked. In actuality, information supports the conclusion that both types of waste were leaked from tank A-105 but, the quantity of each type lost can't be estimated from available data. By assuming the radioactivity detected in the laterals is attributable to only one waste type the range of waste volume leaked from tank A-105 can be estimated as follows:

\section{Assumptions/ Inputs:}

- Soil density $=1.7 \mathrm{~g} / \mathrm{cc}$

- Distance to lateral below base of tank $=10 \mathrm{ft}$

- Cs Sorption capacity $=4.0 \mathrm{E} 7 \mathrm{pCi} / \mathrm{g}(\mathrm{RPP}-\mathrm{ENV}-33418)$

- Assume waste does not extend below laterals based on Cs-Sorption chemistry.

- Assume lateral gamma measurements are $\mathrm{Cs}^{137}$

- Based on activity in the laterals and where the steel tank liner is ripped, up to $3 / 4$ of the tank circumference ( $75-\mathrm{ft}$ diameter tank) could have leaked

- As a conservative estimate assume the waste spread as much at the base of the tank as at the laterals in a cylindrical distribution

- Calculate estimated leaked waste volume for two cases:

- PUREX supernatant waste concentration, $\mathrm{Cs}^{137}=30.7 \mathrm{Ci} / \mathrm{gal}$ (as of May 1965 from ARH-78)

- B-Plant ion exchange waste concentration, $\mathrm{Cs}^{137}=1.38 \mathrm{Ci} / \mathrm{gal}$ (as of June 1968 from Interoffice Memo 7G420-06-004). 
- Width of contamination at the laterals and base of the tank $=16.8 \mathrm{ft}$ (8.4 outward from tank perimeter and 8.4 under tank). This is based on an average of 5 leak diameter widths measured at the laterals $(30,22,16,8$ and $7 \mathrm{ft})$ at a base concentration of $100 \mathrm{pCi} / \mathrm{g}$ (see Figure 4-9).

\section{Calculation:}

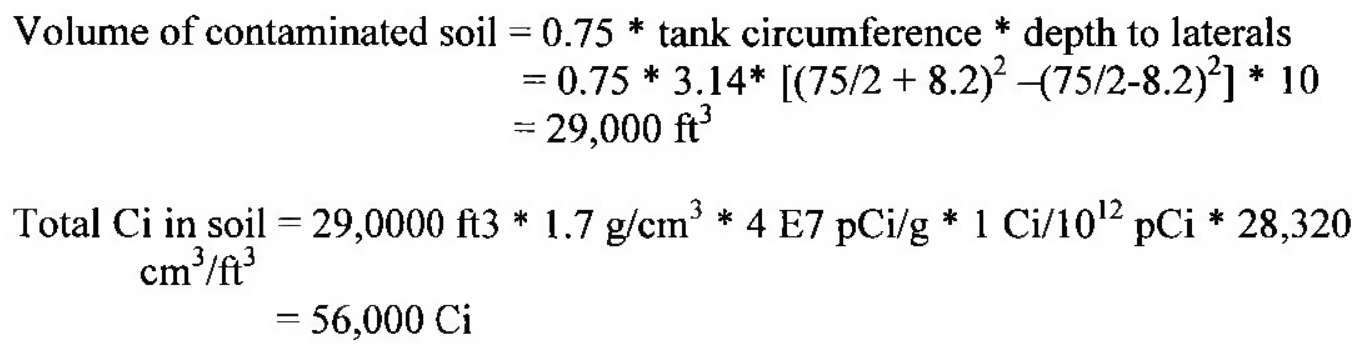

Volume lost:

For PUREX supernatant $=56,000 / 30.7 \mathrm{Ci} / \mathrm{gal}=1,824$ or $\sim 2,000$ gallons

For B-Plant liquid waste $=56,000 / 1.38=40,580 \sim 40,000$ gallons

\subsubsection{A-105 Conclusions}

RPP-23405, revision 2, estimated the volume of waste lost from tank A-105 as 1,000 gallons and the waste type P1 (PUREX HLW supernate) with a $\mathrm{Cs}^{137}$ content of $30.7 \mathrm{Ci} / \mathrm{L}$ or $30,700 \mathrm{Ci}$. The estimated $\mathrm{Cs}^{137}$ content of the waste leakage from tank A-105 in RPP-23405, revision 2 is not consistent with the new conceptual model and will need to be revised. The new conceptual model predicts the estimated waste loss from tank A-105 is 2,000 gallons of PUREX supernate (P1 waste type) or 40,000 gallons of B Plant IX waste (BIX waste type). The new conceptual model for estimating the amount of waste leaked from tank A-105 does not include an estimate for the volume of cooling water potentially leaked from tank A-105. As discussed in Section 4.4.1, an estimated 610,000 gallons of cooling water was added to tank A-105 during November 1970 through December 1978 and 200,000 to 232,000 gallons of cooling water were unaccounted for in the estimate of evaporation. The waste in tank A-105 had been sluiced in 1968 with supernate and leached with sulfuric acid and sluiced in $1969-1970$ (see Section 4.4.1). This sluicing and acid leaching partially dissolved and suspended sludge that was pumped from the tank, leaving a very hard and insoluble sludge in the tank. Because of the mixture rule in RCRA, when a solvent/coolant is added to dangerous waste, the entire mix becomes hazardous/dangerous waste. The addition of water will serve to dilute the activity/concentration of contaminants in tank A-105 and should lead to more widespread distribution if additional waste leakage occurred. Given the insoluble state of the sludge remaining in tank A-105, it is doubtful that water addition to this tank actually dissolved much of the contaminants present. 


\subsection{1-AX Tank Farm}

The 241-AX tanks were designed for the storage of boiling waste generated from irradiated fuel reprocessing at the 202-A PUREX Plant. The 241-AX tanks have three unique design features which are airlift circulators for cooling the boiling wastes, an underground vessel ventilation header to remove condensate and volatiles, and an internal leak detection system. These unique design features are discussed further in section 4.5.1. An understanding of the 241-AX tank design features aides in the discussion of the historical waste loss events associated with tanks 241-AX-102 (section 4.6) and 241-AX104 (section 4.7), as well as the unplanned waste release events in the 241-A and 241-AX Tank Farms (section 4.8).

\subsubsection{1-AX Tank Design Features}

The 241-AX Tank Farm contains four, one million gallon capacity single-shell tanks. A cross section of a 241-AX tank is shown in Figure 4-12 (RL-SEP-9). The 241-AX tanks consist of a 75-ft diameter, carbon steel liner inside a concrete tank. The tank steel bottoms intersected the sidewalls orthogonally (similar to 241-AX and 241-SX tanks), rather than the dished bottoms of earlier designed tank farms. The concrete thickness is $1.5-\mathrm{ft}$ on the tank bottom, $2-\mathrm{ft}$ to $1.25-\mathrm{ft}$ on the side walls, and $1.25-\mathrm{ft}$ for the tank dome. The concrete tank dome thickness increases to $\sim 5$ - $\mathrm{ft}$ along the sidewalls. Each tank was originally equipped with 54 risers that penetrated the tank dome and 22 airlift circulators that were operators to suspend solids, mix the tank contents, and dissipate heat.

The 241-AX tanks were originally designed to contain liquid and solid wastes at a maximum temperature of $350^{\circ} \mathrm{F}$ (RPP-10435 page A-43). Wastes at higher temperatures could cause buckling of the steel liner and/or damage to the concrete shell.

Each 241-AX tank has its own internal leak detection system consisting of a network of drain slots in the concrete base immediately below the carbon steel liner. A 12-inch carbon steel pipe connects the drain network with a leak detection well. The sixty-foot deep well consists of a 24 -inch, schedule 20 carbon steel pipe, surmounted by a concrete pump pit. A waste transfer line connects the leak detection pit with a pump pit atop the 241-AX tank. The leak detection well is vented to the main vent header through a waterfilled seal pot. The leak detection pump pit floor drain into their respective storage tanks through a 4 -inch line that extends 5 feet from the tank bottom.

The 241-AX tanks were vented to an underground vessel ventilation header that connected to 241-A tank farm and later to the 241-AY tank farm. The purpose of this ventilation header was to remove offgas and water vapor from these tanks, which were often operated with the wastes at boiling conditions. Section 4.5.2 includes further discussion on the vessel ventilation header and analyses of samples of condensate collected from this system.

The 241-A and 241-AX tanks were isolated from this ventilation header in the early 1980 's. The design of this ventilation header included a baffled, 20 -inch diameter pipe inside each 241-AX tank, as shown in Figure 4-12. The 20-inch diameter pipe exit the 
tank is connected to a 24 -inch diameter, stainless steel pipe header that is buried a minimum of 4 - $\mathrm{ft}$ below grade. The 24 -inch header ran between the tanks to the 241 - AX152 diverter station and then to the 241-A Tank Farm to tie-in to that farm's ventilation header. The 241-AX ventilation header slopes upward toward the 241-A Farm tie-in. Dresser couplings provide a compression seal on the outer surface of vapor header piping segments that are $\sim 25$ - $\mathrm{ft}$ in length. A Dresser coupling is also used to seal the 20 -inch diameter pipe from each tank to the 24 -inch main vapor header. The couplings provide for expansion and contraction of the vapor header pipe segments.

Figure 4-12 241-AX Tank and Leak Detection Pit

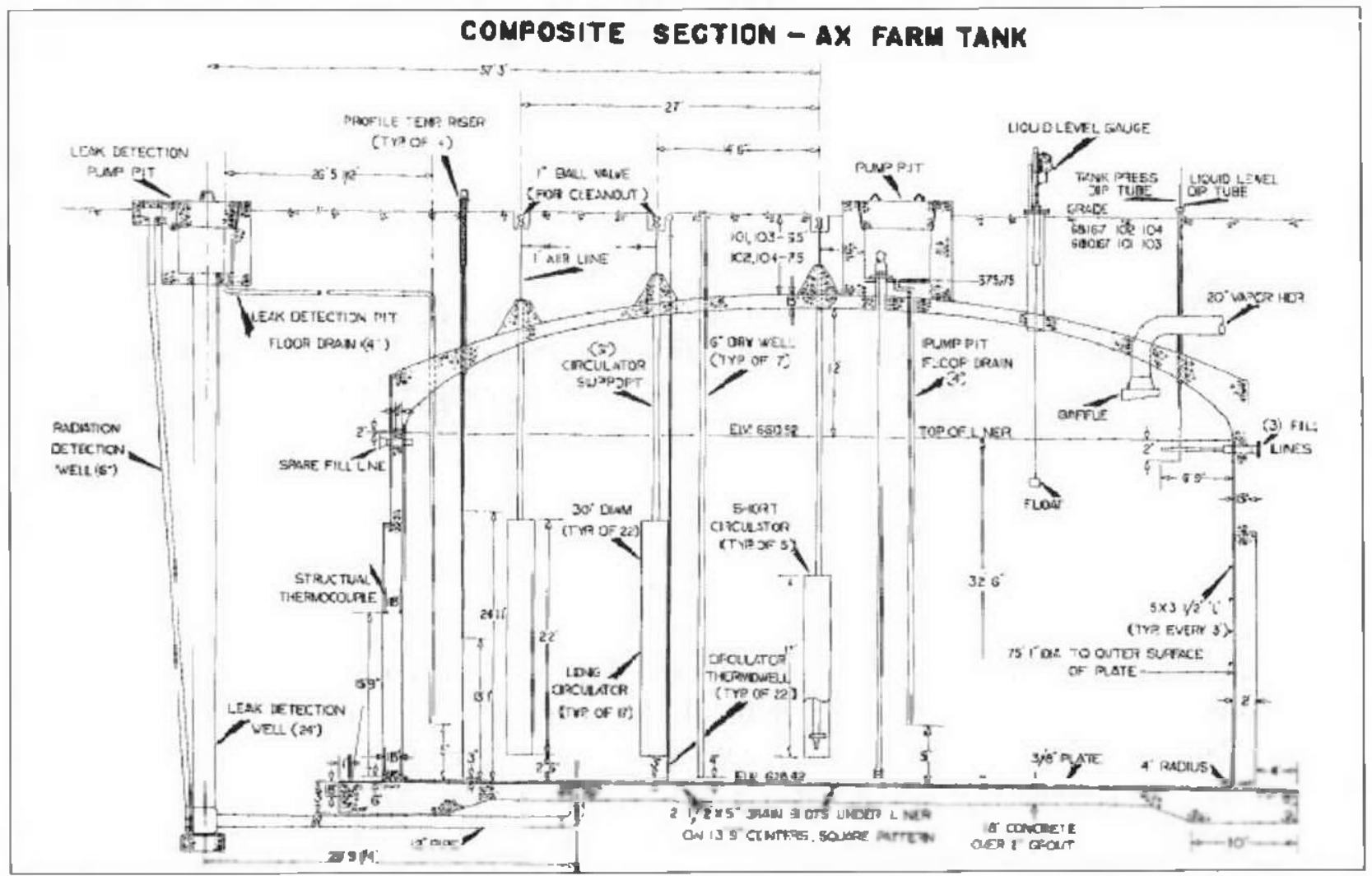

\subsubsection{1-A and 241-AX Tank Farm Process Condensate}

The single-shell tanks in the 241-A and 241-AX tank farms were operated as boiling waste tanks. The heat generated from the decay of radionuclides was sufficient to result in the evaporation of water from the wastes stored in these tanks. The water vapor and other off-gases from the 241-A single-shell tanks was drawn from each tank through an underground 20 -inch diameter pipe that connects to an underground 24-inch diameter pipe (i.e. vapor header). When the 241-AX tank farm was constructed in $1963-64$, a similar vapor header was installed for these four single-shell tanks. An underground 20inch diameter pipe connects from each single-shell tank to an underground 24-inch diameter pipe. The underground 24-inch diameter pipe runs to the 241 -AX-152 diverter 
station. From the 241-AX-152 diverter station, the underground 24-inch diameter pipe from the 241-AX vapor header connects to the 241-A tank farm vapor header.

The 241-A tank farm vapor header connects to underground condensers and deentrainment vessels and then enters the 24I-A-431 fan house and de-entrainment building. The 241-A and 241-AX Tank Farm Process Condensate (TFPC) was removed from the 241-A and 241-AX tank farm off-gases and collected in tank 241-A-417. The off-gas was filtered and discharged through an exhaust stack. Initially, the condensate collected in tank 241-A-417 was either returned to one of the 241-A or 241-AX singleshell tanks or discharged to a crib. In January 1970, a prototype ion exchange system was installed to remove ${ }^{137} \mathrm{Cs}$ from the TFPC prior to discharge to cribs (PR-REPORTJAN70, rev. 1 page AV-2). Table 4-1 summarizes the analyses of the untreated TFPC waste located in reference documentation. The composition of the PUREX HLW supernate in tanks 241-A-101, 241-A-104, and 241-A-106 in September 1964 are provided in Table 4-2 (RL-SEP-183-RD). In comparison with the TFPC, the ${ }^{137} \mathrm{Cs}$ concentration in the PUREX HLW supernate was approximately 100,000 times higher.

While not reported in these analyses, ${ }^{60} \mathrm{Co}$ was present in relatively small concentrations in the TFPC waste. The 216-A-8 crib received the TFPC waste from November 1955 through May 1956 and from April 1966 through April 1971. The 216-A-8 crib also received process condensate from the 241-AY tank farm after April 1971. The 216-A-24 crib received TFPC waste from May 1956 through April 1966.

In June 1963, the 216-A-24 crib was reported to have received $0.0124 \mathrm{Ci}$ of ${ }^{60} \mathrm{Co}$ in $1.31 \mathrm{E}+06$ liters of waste or $\sim 9.5 \mathrm{E}-06 \mu \mathrm{Ci} / \mathrm{ml}$ (HW-80877 page 12). In December 1963 , the 216-A-24 crib was reported to have received $0.0248 \mathrm{Ci}$ of ${ }^{60} \mathrm{Co}$ in $1.36 \mathrm{E}+06$ liters of waste or $\sim 1.8 \mathrm{E}-05 \mu \mathrm{Ci} / \mathrm{ml}$ (HW-80877 page 12). The TFPC was not reported as containing any ${ }^{60} \mathrm{Co}$ for the other months in 1963. In $1969,0.058 \mathrm{Ci}$ of ${ }^{60} \mathrm{Co}$ were reported to have heen discharged in $6.37 \mathrm{E}+06$ gallons of TFPC to the $216-\mathrm{A}-8 \mathrm{crib}$, or $\sim 2.4 \mathrm{E}-06 \mu \mathrm{Ci} / \mathrm{ml}$. Also, the concentration of ${ }^{60} \mathrm{Co}$ was reported as $2.9 \mathrm{E}-05 \mu \mathrm{Ci} / \mathrm{cc}$ in an April 1957 analysis of the condensate discharged to the 216-A-8 crib (HW-51399 page 5). This information confirms that ${ }^{60} \mathrm{Co}$ was present in the TFPC as relatively small concentrations. 
RPP-ENV-37956 Rev. 1

Table 4-1 241-A Tank Farm Process Condensate Analyses

\begin{tabular}{|c|c|c|c|c|c|c|c|}
\hline \multirow{4}{*}{ Constituent } & \multicolumn{7}{|c|}{ 241-A Tank Farm Process Condensate } \\
\hline & \multirow[t]{2}{*}{$\begin{array}{c}1959 \\
\text { Anglyses }\end{array}$} & \multirow[t]{2}{*}{$\begin{array}{c}1960 \\
\text { Anglysis }\end{array}$} & \multicolumn{3}{|c|}{$\begin{array}{c}1969 \\
\text { Analyses }^{6}\end{array}$} & \multirow[t]{2}{*}{$\begin{array}{c}1961 \\
\text { Analyses? }\end{array}$} & \multirow[t]{2}{*}{ May 8, 1978 } \\
\hline & & & $\# 1$ & $\# 2$ & $\# 3$ & & \\
\hline & $\mathrm{mg} / \mathrm{L}$ & $\mathbf{m g} / \mathbf{l}$. & $\mathrm{mg} / \mathrm{L}$ & & & $\mathrm{mg} / \mathrm{L}$ & $\mathrm{mg} / \mathrm{L}$ \\
\hline Tri-butyl or butyl phosphate & 30 to 190 & 120 & not reported & & & 30 to 200 & not reported \\
\hline Shell spray base (or hydrocarbon) & $<10$ & not reported & not reported & & & 10 to 70 & not reported \\
\hline Ammonium ion & not reported & not reported & 630 & 430 & 156 & 35 to 200 & not reported \\
\hline Sodium & $<1.5$ & not reported & not reported & & & 1 to 2 & not reported \\
\hline Nitrate & not reported & not reported & not reported & & & 1 to 5 & not reported \\
\hline Nitrite & not reported & not reported & not reported & & & 5 to 10 & not reported \\
\hline Iron & 0.1 & not reported & not reported & & & not reported & not reported \\
\hline \multirow{2}{*}{$\begin{array}{l}\text { Nickel, chromium, copper, aluminum, } \\
\text { zirconium, manganese, cobalt, calcium, } \\
\text { and magnesium (each) }\end{array}$} & $<0.01$ & not reported & not reported & & & not reported & not reported \\
\hline & $\mu \mathrm{Ci} / \mathrm{ml}$ & $\mu \mathrm{Ci} / \mathrm{ml}$ & $\mu \mathrm{Ci} / \mathrm{ml}$ & & & $\mu \mathrm{Ci} / \mathrm{ml}$ & $\mu \mathrm{Ci} / \mathrm{ml}$ \\
\hline $\mathrm{Cs}-137$ & $23 \mathrm{E}-02$ & $3.2 \mathrm{E}-02$ & $5 \mathrm{E}-3$ & $7.4 \mathrm{E}-3$ & $88 \mathrm{~F}-3$ & $1 \mathrm{E}-2$ & $2.1 E-4$ \\
\hline Nb-95 & $25 \mathrm{E}-2$ & not reported & & & & $1 \mathrm{E}-2$ & not reported \\
\hline $\mathrm{Zx}-95$ & $1.2 \mathrm{E}-2$ & not reported & & & & IE-2 & not reported \\
\hline $\mathbf{R u}-106$ & $7.2 \mathrm{E}-3$ & not reported & & & & IE-3 & $2.2 \mathrm{E}-4$ \\
\hline $\mathrm{Ru}-\mathrm{i} 03$ & $5.6 \mathrm{E}-3$ & not reported & & & & not reported & not reported \\
\hline Sr-89 & $3.7 \mathrm{E}-3$ & not reported & & & & 1E-3 & not reported \\
\hline Sr-90 & $4.4 \mathrm{E}-4$ & & & & & $1 \mathrm{E}-4$ & not reported \\
\hline Sr-89/90 & not reported & 8.4F-04 & & & & not reported & $3.3 \mathrm{E}-4$ \\
\hline $\mathrm{Ce}-144$ & $5 \mathrm{E}-3$ & not reported & & & & $1 \mathrm{E}-3$ & $1.45 \mathrm{E}-5$ \\
\hline Y-9] & $3 \mathrm{E}-3$ & not reported & & & & $1 \mathrm{E}-3$ & not reponted \\
\hline $\mathrm{I}-13 \mathrm{I}$ & not reported & not reported & & & & $1 \mathrm{E}-5$ & not reported \\
\hline Gross beta & $9.1 \mathrm{E}-2$ & not reported & & & & not reported & not reported \\
\hline Gross alpha & $<1.2 \mathrm{E}-6$ & not reported & & & & not reported & not reported \\
\hline
\end{tabular}

${ }^{4} \mathrm{HW}-63949$, pg. 17

${ }^{5}$ HW-66276, pg. 14-17

${ }^{6}$ Mercer 1969; Values reported are for three separate experiments. Waste sluicing was being conducted during run $\# 3$.

${ }^{7} \mathrm{HW}-79174$, pg. 16-17

${ }^{8}$ IDMS Accession \# D194035016 
Table 4-2 PUREX HLW Supernate Analyses (9/2/1964)

\begin{tabular}{|c|c|c|c|}
\hline Constituent & $241-A-101$ & $241-\overline{A-104}$ & 241-A-106 \\
\hline & $\mathrm{mg} / \mathrm{L}$ & $\mathrm{mg} / \mathrm{l}$ & $\mathrm{mg} / \mathrm{L}$ \\
\hline Sodium & $1.5 \mathrm{E}+05$ & $1.5 \mathrm{E}+05$ & $1.6 \mathrm{E}+05$ \\
\hline Nitrate & $1.4 \mathrm{E}+04$ & $4.1 \mathrm{~F}+04$ & $3.6 \mathrm{E}+04$ \\
\hline Nitrite & $1.55 \mathrm{E}+05$ & $1.57 \mathrm{E}+05$ & $1.54 \mathrm{E}+05$ \\
\hline Sulfate & $1.4 \mathrm{E}+04$ & $1.8 \mathrm{E}+04$ & $1.3 \mathrm{E}+04$ \\
\hline \multirow[t]{2}{*}{ Phosphate } & $5.4 \mathrm{E}+03$ & $2.2 \mathrm{E}+03$ & $9.0 \mathrm{E}+02$ \\
\hline & & & \\
\hline $\mathrm{Cs}-13 \overline{7}$ & $\frac{\mu \mathrm{Ci} / \mathrm{ml}}{495 \mathrm{E}+03}$ & $\frac{\mu \mathrm{Ci} / \mathrm{ml}}{3.4 \mathrm{~F}+03}$ & $\frac{\mu \mathrm{Ci} / \mathrm{ml}}{585 \mathrm{~F}+03}$ \\
\hline Nb-95 & not reported & not reported & not reported \\
\hline $\mathrm{Zr}-95$ & 81 & 37 & $1.58 \mathrm{E}+02$ \\
\hline $\mathrm{Ru}-106$ & $3.97 \mathrm{E}+02$ & 58.5 & $1.89 \mathrm{E}+02$ \\
\hline Ru-103 & not reported & not reported & not reported \\
\hline Sr-89 & not reported & not reported & not reported \\
\hline $\mathrm{Sr}-90$ & not reported & not reported & not reported \\
\hline Sr $-89 / 90$ & not reported & not reported & not reported \\
\hline $\mathrm{Ce}-144$ & $1.49 \mathrm{E}+02$ & 94.5 & $1.71 \mathrm{E}+02$ \\
\hline
\end{tabular}

\subsection{Tank AX-102 Waste Loss Event}

\subsubsection{Tank AX-102 Operating Summary}

SST 241-AX-102 was construction complete in January 1965 (HAN-90650 page 16). Although SST AX-102 was originally constructed to receive PUREX HI.W, the operational history of SST AX-102 is quite varied, as shown in Figure 4-13. Waste types stored in SST AX-102 included PUREX HLW, flushes from SST A-105 in preparation for sluicing, B Plant waste, sludge sluicing, and complexed waste. The complexant supernate was removed from SST AX-102 in 1980, followed by saltwell pumping in 1983 and interim stabilization in 1988.

Tank AX-102 was classified as an assumed leaker in September 1988 based an estimated 3,400 gallon liquid level decline reported to have occurred from June 18, 1984 through May 27, 1988. However, no radioactivity corresponding to tank waste leakage was detected in the leak detection pit or the drywells associated with this tank. These operational periods for SST AX-102 are discussed below. 
Figure 4-13 Tank AX-102 Operational Timeline (1965-1988)

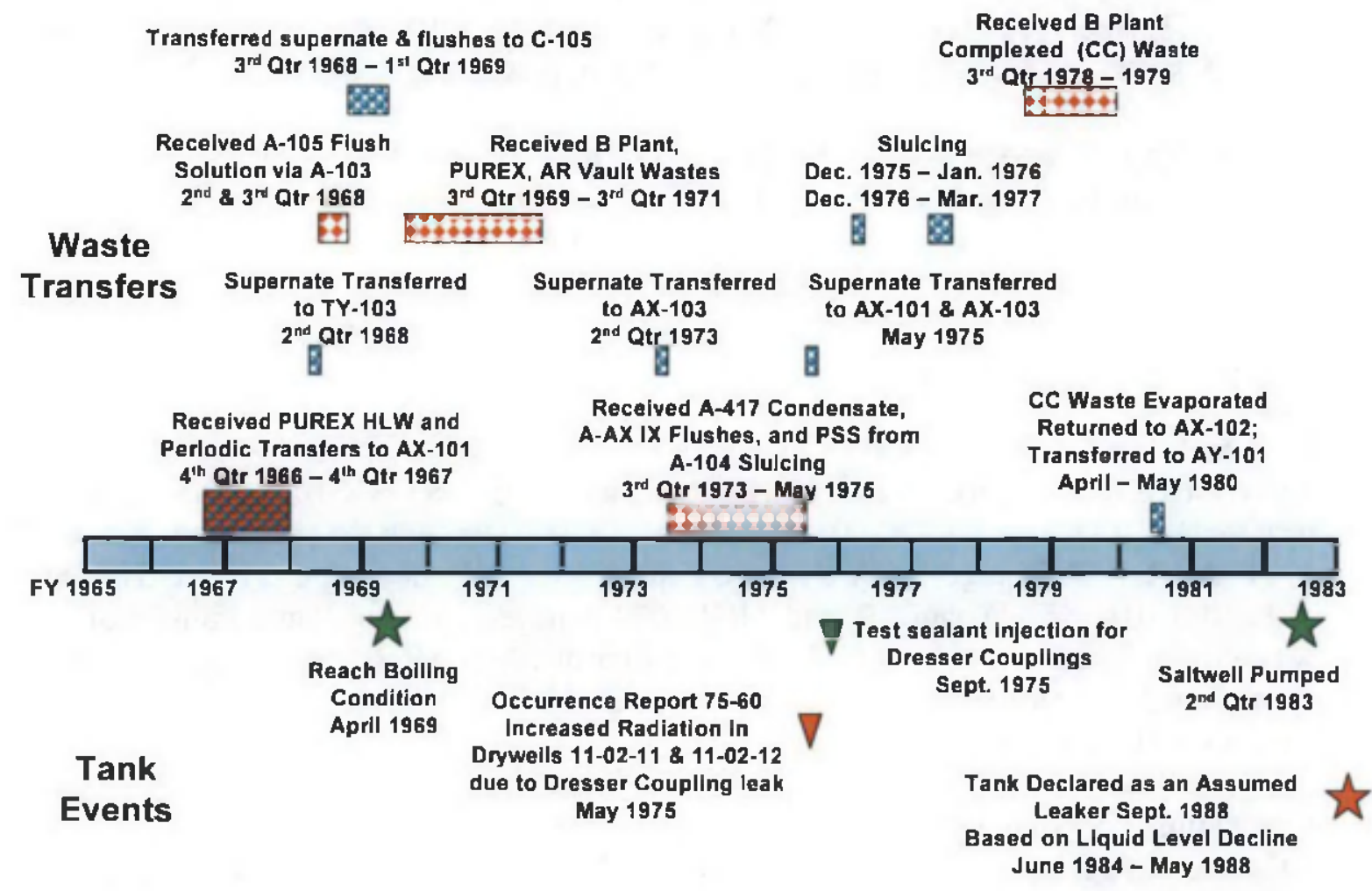

\subsubsection{Tank AX-102 Operating History}

PUREX HLW Receipt (1965 - 1967): Water was added to the tank in the fourth quarter of FY 1965 (RL-SEP-821 page 8) and the first quarter of FY 1966 (RL-SEP-923 page 8). The water added to SST AX-102 was likely done as part of the preheating procedure. The standard practice employed for the 241-AX tanks was to add water and preheat the water prior to adding boiling waste from the PUREX plant.

In the fourth quarter of 1966, SST AX-102 received HLW from the PUREX plant (ISO538 page 8). Additional PUREX plant HLW was received in the first quarter of FY 1967 as well as some concentrated PUREX HLW from SST AX-101, which was equipped with a steam coil (ISO-674 page 8 and H-2-34266). Approximately 883,000 gallons of PUREX HLW was contained in SST AX-102 at the end of the first quarter of FY 1967, but the tank temperature had not reached conditions for waste boiling. From January 1967 through September 1967, SST AX-102 periodically received HLW from the PUREX plant and transfers of supernate to SST AX-101 were conducted. 
SST A-105 Flushes Receipt (1968): In the second quarter of FY 1968, the PUREX HLW supernate was transferred from SST AX-102 to SST TY-103 (ARH-534 page 8) in order to use SST AX-102 for receiving supernate flushes from SST A-105, in preparation for sluicing SST A-105 (ARH-534 page 9). SST AX-102 continued to receive SST A-105 supernate via SST A-103 in the third quarter of FY 1968 (ARH-721 page 9). Periodic transfers of supernate were made from SST AX-102 to C-105 from the third quarter 1968 (ARH-871 page 9) through the first quarter of FY 1969 (ARH-1061 page 10) to stage the PUREX supernate (PSN) for cesium ion exchange processing in the 221-B Plant.

B Plant Waste Evaporation (1969 - 1972): SST AX-102 was then flushed and preheated for service in the second quarter of FY 1969 to receive waste (ARH-1200 A page 10). The flush solutions were transferred to SST C-105 for staging to the cesium ion exchange process in the 221-B Plant. SST AX-102 was reported to have reached boiling conditions in April 1969 (RHO-R-39), but documented temperature data was found for only the period of July 1969 through September 1971, which shows the waste temperature varied from 220 to $250^{\circ} \mathrm{F}$ (RHO-CD-1172 pages B-58 and B-59). SST AX-102 received B Plant waste and small transfers of PUREX HLW in the third and fourth quarters of FY 1969 (ARH-1200 B page 10 and ARH-1200 C page 10). SST AX-102 continued to receive $B$ Plant waste from the first quarter of FY 1970 through the second quarter of FY 1971 (ARH-1200 D page 10, ARH-1666 A page 10, ARH-1666 B page 10, ARH-1666 C page 10, ARH-1666 D page 10, and ARH-2074 A page 10 ), as well as a transfer of waste from the 244-AR Vault in the third quarter of 1971 (ARH-2074 B page 10). The wastes received into SST AX-102 were evaporated with the condensate being routed to tank A-417 and discharged to the 216-A-24 crib.

Preparations for Sluicing (1973 - 1975): No waste transfer activities involving SST AX102 occurred again until the second quarter of FY 1973, when the pumpable supernate was transferred to SST AX-103 for staging to the cesium ion exchange process in the 221-B Plant (ARH-2794 A page 9). SST AX-103 contained 50,000-gallons of sludge and 63,000-gallon of supernate following this transfer. Tank A-417 condensate, water, and A-AX ion exchange column flushes were periodically added to SST AX-102 throughout the remainder of FY 1973, FY 1974, and through May 1975 (IDMS Accession \#D195005364), as well as some PUREX Sludge Supernate (PSS) solution from SST A-104 sluicing operations in the fourth quarter of 1974 (ARH-CD-133 C page 9). The supernate in SST AX-102 was transferred to SSTs AX-101 and AX-103 in May 1975 in preparation for sluicing the sludge (ARH-CD-336 B page 9 and IDMS Accession \#D195005364). However, sluicing of SST AX-102 was postponed when an increase in radiation was detected in drywell 11-02-11.

Off-gas Vapor Header Dresser Coupling Leak (1975): Following the transfer of supernate from SST AX-102 in May 1975, an increase in the radiation at the 55-foot level was detected in drywell 11-02-11 on May 16, 1975. This drywell is located approximately 10-feet from SST AX-102. Water was added to the tank to cover the solids on May 16, 1975. 
Drywell 11-02-11 was first monitored on February 11, 1975 and indicated a peak in radiation at $38 \mathrm{cps}$ at 56 feet below grade. The radiation continued to increase at the 55 feet below grade until $\sim 200 \mathrm{cps}$ were detected in May 16, 1975 and $\sim 380 \mathrm{cps}$ in June 23, 1975. The radioactivity detected in drywell 11-02-11 was attributed to ruthenium-106 (IDMS Accession \#D195005364). This was later confirmed in 2001 when the historical gross gamma radiation detected in drywells 11-02-11 and 11-02-12 ${ }^{9}$ were correlated to ruthenium-106 decay rate for radioactivity detected at 50-60-ft bgs in drywell 11-02-11 and 32-50-ft bgs in drywell 11-02-12. The historical gross gamma radiation detected 3250 - $\mathrm{ft}$ bgs in drywell 11-02-12 was also correlated to cobalt-60 decay rate as well (RPP8821 pages $31-42$ ).

Auger drilling was conducted adjacent to the Dresser couplings in the off-gas vapor header connecting the 241-AX tanks. Highly contaminated soil was detected at a depth of 10-feet adjacent to the Dresser coupling joining the 20-inch vapor header from SST AX-102 to the main 24-inch header and the Dresser coupling atop SST AX-104. A new drywell, 11-02-12, was installed in May 1975 and first monitored in May 28, 1975, indicating radiation peaks of $3,027 \mathrm{cps}$ (probe 14 ; must multiply by 10 for comparison with other AX-102 drywells) at 36-feet below grade and $750 \mathrm{cps}$ (probe 14; must multiply by 10 for comparison with other AX-102 drywells) at 48 -feet below grade. One of the Dresser couplings for SST AX-102 is located between the 11-o'clock and 12o'clock positions, nearby drywells 11-02-11 and 11-02-12 (installed in May 1975).

Further monitoring of the radioactivity detected adjacent to SST AX-102 was conducted in June 1975 using experimental leak detection systems developed by Battelle Northwest and Boeing (IDMS Accession \#D197137077 and ARH-LD-120 page 33). Based on the depth and radionuclides detected in drywells 11-02-11 and 11-02-12, ARHCO personnel determined the Dresser coupling for SST AX-102 was the source of the activity (IDMS Accession \#D195005364 and IDMS Accession \#D194050777). No estimate was located for the estimated volume and composition of the condensate leaked from the 241-AX vapor header.

ARHCO personnel conducted a field test to repair the $241-\mathrm{AX}$ vapor header by injecting a sealant around the Dresser couplings. Approximately 660 gallons of water-based asphalt emulsion sealant were injected at a depth of 9 to 14-feet in four wells that were drilled around a suspected leaking Dresser coupling for tank AX-102. Injection of the sealant resulted in contamination coming to the surface. Six inches of contaminated soil were removed and replaced with gravel to stabilize the contaminated areas (ARH-CD587). However, the effectiveness of the sealant was inconclusive and migration of contamination from the vapor header continued. ARHCO personnel reported the results of the 241-AX vapor header sealant test to the U.S. Energy Research and Development Administration and recommended that normal operations continue in the 241-AX farm,

\footnotetext{
${ }^{9}$ For drywells, typically a scintillation probe (somelimes referred to as probe 4) and a GM probe were used for measuring radioactivity. A third probe used in drywells was a shielded scintiliation probe (SSP), sometimes referred to as probe 14 (SD-WM-TI356). The relationship between the probe 14 and the unshielded probe 4 is approximately a factor of 10 . Most of the earlier drywel] data in 24I-AX Farm were acquired with probe 4. One exception was borehole 11-02-12 where probe 14 data were acquired in addition to probe 4 data. The probe 14 data should be multiplied by 10 for comparison with the probe 4 data.
} 
using continued dry well monitoring to "... provide assurance that any further vapor header leakage will be detected (IDMS Accession \#D195006631).

Sluicing (1975 - 1977): Sluicing of the SST AX-102 sludge was initiated in late December 1975 to make this tank available for receipt of 242-A Evaporator bottoms (ARH-LD-212 B page 21). Sluicing of tank AX-102 to 244-AR Vault continued in January 1976, but was interrupted in February 1976 when a new slurry pump was needed to increase sludge removal (ARH-LD-214 B page 22). Sluicing operations were then switched to SST AX-103 while the new slurry pump was being readied for installation in SST AX-102. Sluicing of SST AX-102 was resumed in December 1976 (ARH-LD-224 B page 11) and was halted in March 1977 (ARH-LD-227 B page 24) when the sludge removal was no longer effective. Following completion of sluicing, SST AX-102 was estimated to contain approximately 5,100-gallons of sludge (IDMS Accession \#293003399).

Complexed Waste (1977 - 1980): Following completion of sluicing, SST AX-102 received dilute complexed waste from 221-B Plant from 1978 through 1979. In April 1980 , the dilute complexed waste was transferred to SST A-102 and processed in two passes through the 242-A Evaporator, with the concentrate from both passes being received back into SST AX-102 (RHO-CD-80-1045 6). Table 4-3 summarizes the analyses of the complexant concentrate waste stored in SST AX-102 based on a sample obtained on April 30, 1980 (RHO-CD-80-1045 6 pages 4 and F-1). The complexant concentrate waste was transferred from SST AX-102 to DST AY-101 in May 1980, leaving an estimated 46,000 gallons of supernate, saltcake, and sludge in AX-102 (RHOCD-14 May 1980). The waste volume in SST AX-102 was later revised to 52,000gallons based on in-tank photographs.

Table 4-3 Tank AX-102 Complexant Concentrate Composition (4/30/1980)

\begin{tabular}{|l|l|l|}
\hline \multicolumn{1}{|c|}{ Analyte } & \multicolumn{1}{c|}{ Value } & \multicolumn{1}{c|}{ Units } \\
\hline SpG & 1.26 & $\mathrm{gm} / \mathrm{ml}$ \\
\hline wt \% water & 70 & $\mathrm{wt} \%$ \\
\hline $\mathrm{Al}$ & 0.186 & $\mathrm{M}$ \\
\hline $\mathrm{OH}$ & 0.372 & $\mathrm{M}$ \\
\hline $\mathrm{NO} 3$ & 1.76 & $\mathrm{M}$ \\
\hline $\mathrm{NO} 2$ & 0.811 & $\mathrm{M}$ \\
\hline $\mathrm{PO} 4$ & 0.0437 & $\mathrm{M}$ \\
\hline $\mathrm{CO} 3$ & 0.937 & $\mathrm{M}$ \\
\hline $\mathrm{Sr}-89 / 90$ & $5.64 \mathrm{E}-02$ & $\mathrm{Ci} / \mathrm{L}$ \\
\hline $\mathrm{Cs}-137$ & 0.55 & $\mathrm{Ci} / \mathrm{L}$ \\
\hline $\mathrm{Pu}$ & $7.89 \mathrm{E}-04$ & $\mathrm{gm} / \mathrm{L}$ \\
\hline
\end{tabular}

Saltwell Pumping and Interim Stabilization (1983 and 1988): SST AX-102 was saltwell pumped to DST AN-101 in the second quarter of FY 1983. SST AX-102 was estimated to contain 23,000-gallons of supernate and 29,000-gallons of sludge as of November 1983 (IDMS Accession \#D194031937). 
There was some concern that SST AX-102 was slowly leaking from January 1981 through December 1982. A decrease of 0.75 -inches in waste level was observed during this period. However, the tank was connected to the 702-A ventilation system and the decrease was shown to be attributable to evaporation. After removal of the tank from the $702-$ A ventilation system in November 1982, the waste level was stable at 18.75 to 19 inches from January 1983 through February 1984. The temperature of the sludge in SST AX-102 was reported to be $165+/-5^{\circ} \mathrm{F}$ (February 1984) and some waste loss through evaporation is expected (IDMS Accession \#D194030828).

Another surface level decrease was reported July 26, 1988 for SST AX-102 (WHC-UO88-029-TF-04). The waste level in AX-102 decreased from 18.75-inches on June 18, 1984 to 17.5-inches on May 27, 1988, a decline of 1.25-inches ( 3,400-gallons). An evaluation of the integrity of SST AX-102 was conducted and revealed the following (IDMS Accession \#292-001159):

- The liquid level drop in tank AX-102 was shown to be statistically significant

- Evaporation could only account for $\sim 25 \%$ of the waste level decline

- The liquid level in SST AX-102 returned to 18.75-inches as of July 7, 1988, but this was discounted by the 1988 tank integrity review team

- In-tank photographs from May 14, 1981, August 18, 1987, and June 6, 1988 all showed a liquid surface covered by a thin film of floating solids. However, only a small portion of the waste surface was visible, with the remainder obstructed by haze and the airlift circulators. The manual tape gauge was on the opposite side of the tank and could not be seen.

- Data for the leak detection pit and ten external drywells associated with tank AX-102 were reviewed and the 1988 tank integrity review team deemed the readings were not indicative of a tank leak however no values were reported in the reference (IDMS Accession \#293-002393).

Westinghouse Hanford Company conducted a peer review of this tank integrity assessment and concluded the tank should be reclassified as an assumed leaker. The U.S. DOE was notified of the change in status for SST AX-102 on September 6, 1988 (IDMS Accession \#292-001156).

Stabilization of SST AX-102 was conducted in August 1988 with 13,200-gallons of liquid removed using a submersible pump (IDMS Accession \#292-001152 and HNF-SDRE-TI-178, rev. 9 pages 28-29). In-tank photographs taken on September 1, 1988 were reviewed and showed a liquid pool covering approximately $20 \%$ of the surface. The estimated drainable liquid remaining in the tank was estimated to be 2,750 gallons, with 35,750 gallons of saltcake and sludge present (HNF-SD-RE-TI-178, rev. 9 pages 28-29).

Further settling of the waste surface following interim stabilization was reported to have occurred in October 1988, prompting re-estimating of the waste level as 13.25-inches or $\sim 36,400$-gallons (TFSA\&S-89-48). An additional decline in the waste level for SST AX-102 to 12-inches ( $-33,000$-gallons) was reported to have occurred in May 1989 and after investigation was determined to be due to further settling of the waste. The leak 
detection pit and the drywells associated with SST AX-102 did not show evidence of a tank waste loss (WHC-UO-89-023-TF-05).

Leak Detection Pit Water Loss: The leak detection pit for SST AX-102 was reported in May 1975 to be contaminated and possibly leaking (IDMS Accession \#D195005364). Efforts to isolate the pit and fill the seal pot line connecting the leak detection pit to the 241-AX vapor header did not stop this leak. Initially, the leak rate from the pit was 0.3 gallons per day in May 16, 1975, but increased to 1.2 gallons per day by June 24, 1975. The leak rate seems to be related to the depth of the liquid in the leak detection pit. No radioactivity was detected in samples of water taken from the AX-102 leak detection pit in 1975. However, contamination was detected later (March 1976) in this leak detection pit (ARH-LD-215 B page 14). The contamination was not sufficient to be attributable to waste loss from SST AX-102. The source of contamination was attributed to the pump out header for all of the 241-AX leak detection pits which connects to the same header used to transfer waste from the 241-AX tanks. Any drainage from this header could cause contamination of the leak detection pits (IDMS Accession \#D194044995 pages 23).

\subsubsection{Tank AX-102 Waste Loss Estimate}

The historically estimated waste loss from tank $241-\mathrm{AX}-102$ is 3,400-gallons and is based solely on the 1.25-inch liquid level decline reported in WHC-UO-88-029-TF-04. No increase in radiation was detected in the $\mathrm{AX}-102$ leak detection pit or drywells associated with this tank. However, this estimate for the volume of waste loss from tank 241-AX-102 is inconsistent with the relatively low level of radiation detected in the leak detection pit and drywells associated with this tank. If 3,400-gallons of the complexant concentrate waste had actually leaked from SST AX-102 to the soil from June 18, 1984 through May 27, 1988, the inventory of ${ }^{137} \mathrm{Cs}$ and ${ }^{90} \mathrm{Sr}$ leak would equate to 4,500 and 2,190 curies, respectively based on the sample analysis discussed in the subsequent paragraph. The gamma radiation detected in the associated drywells and leak detection pit is expected to be far higher than actually observed if this quantity of these two radionuclides were leaked to the soil. Therefore, it is unlikely that SST AX-102 actually leaked 3,400-gallons of complexant concentrate waste to the soil.

A sample of the liquid in SST AX-102 was obtained in August 1988 and is reported in Appendix B of HNF-SD-WM-ER-472, rev. 2, Tank Characterization Report for SingleShell Tank 241-AX-102. Select analytes are reported in the August 1988 tank AX-102 liquid sample are summarized in Table 4-4. This waste composition should be representative of the waste leaked from the tank. 
Table 4-4 Tank AX-102 Liquid Composition (8/1988)

\begin{tabular}{|l|c|c|}
\hline \multicolumn{1}{|c|}{ Analyte } & Value & Units \\
\hline $\mathrm{Al}$ & 0.006 & Molarity \\
\hline $\mathrm{Cr}$ & 0.004 & Molarity \\
\hline $\mathrm{Na}$ & 7.32 & Molarity \\
\hline $\mathrm{K}$ & 0.002 & Molarity \\
\hline $\mathrm{pH}$ & 11.3 & \\
\hline $\mathrm{NO} 3$ & 3.7 & Molarity \\
\hline $\mathrm{NO} 2$ & 1.4 & Molarity \\
\hline $\mathrm{PO} 4$ & $<0.056$ & Molarity \\
\hline $\mathrm{CO} 3$ & 0.98 & Molarity \\
\hline $\mathrm{NH} 4$ & 0.028 & Molarity \\
\hline $\mathrm{TOC}$ & 36.8 & $\mathrm{~g} / \mathrm{L}$ \\
\hline $\mathrm{Sr}-90$ & $1.7 \mathrm{E}+05$ & $\mu \mathrm{Ci} / \mathrm{L}$ \\
\hline $\mathrm{Cs}-137$ & $3.5 \mathrm{E}+05$ & $\mu \mathrm{Ci} / \mathrm{L}$ \\
\hline $\mathrm{Pu}$ & 97 & $\mu \mathrm{Ci} / \mathrm{L}$ \\
\hline $\mathrm{Am}$ & 1,000 & $\mu \mathrm{Ci} / \mathrm{L}$ \\
\hline
\end{tabular}

The Field Investigation Report for Waste Management Areas $C$ and A-AX(RPP-35484) did not conduct specific characterization activities around tank AX-102. RPP-35484 states the primary indication of tank waste loss began in May 1975, when an increase in gross gamma levels from 38 to $152 \mathrm{c} / \mathrm{s}$ occurred at approximately $55-\mathrm{ft}$ bgs in drywell 11 02-11. By September 1975, the gamma level increased to $1,021 \mathrm{c} / \mathrm{s}$ and stayed at that level through December 1976. Additional drywells 11-02-12 and 11-02-22 were constructed shortly after May 1975, but only drywell 11-02-12 showed anomalous radiation levels. Significant contamination was encountered in the first measurement essentially throughout the drywell, as shown in Figure 4-14 (GJO-97-14-TAR, GJO-HAN-12). Current spectral gamma analyses for drywells 11-02-12 show $\mathrm{Cs}^{137}$ as the dominant gamma emitter at approximately $12-\mathrm{ft}$ bgs and only cobalt- 60 at approximately $0.1 \mathrm{pCi} / \mathrm{g}$ from 30 to $45-\mathrm{ft}$ bgs. Other short-lived gamma emitters present in 1975 would have decayed below detection limits by the mid 1990s, when these measurements were taken. Other drywells nearby SST AX-102 do not show any significant contamination, as shown in Figure 4-15, Figure 4-16, and Figure 4-17 (GJO-97-14-TAR, GJO-HAN-12). Migration of Cs-137 contamination down the inside or outside of the drywell casing is suspected to have affected the distribution of some of the contamination detected in the drywells. Much of the bias of the drywell log data that is due to drywell migration effects was removed from the surveys and is designated as "removed" in these figures.

RPP-35484 further states "The most likely source of waste release from tank AX-102 was identified as a dresser coupling failure between a 20 -in. buried vapor line and the tank vessel vent system header. In late 1975, asphalt sealant was injected into the soil in an attempt to repair the dresser couple. The drywell gamma data suggest that relatively little waste entered the soil column after this action was taken." The conclusion of RPP35484 is consistent with the historical information discussed in the previous sections. 
RPP-ENV-37956 Rev. 1

Figure 4-14 Historical Gross Gamma Log Data from Drywell 11-02-12

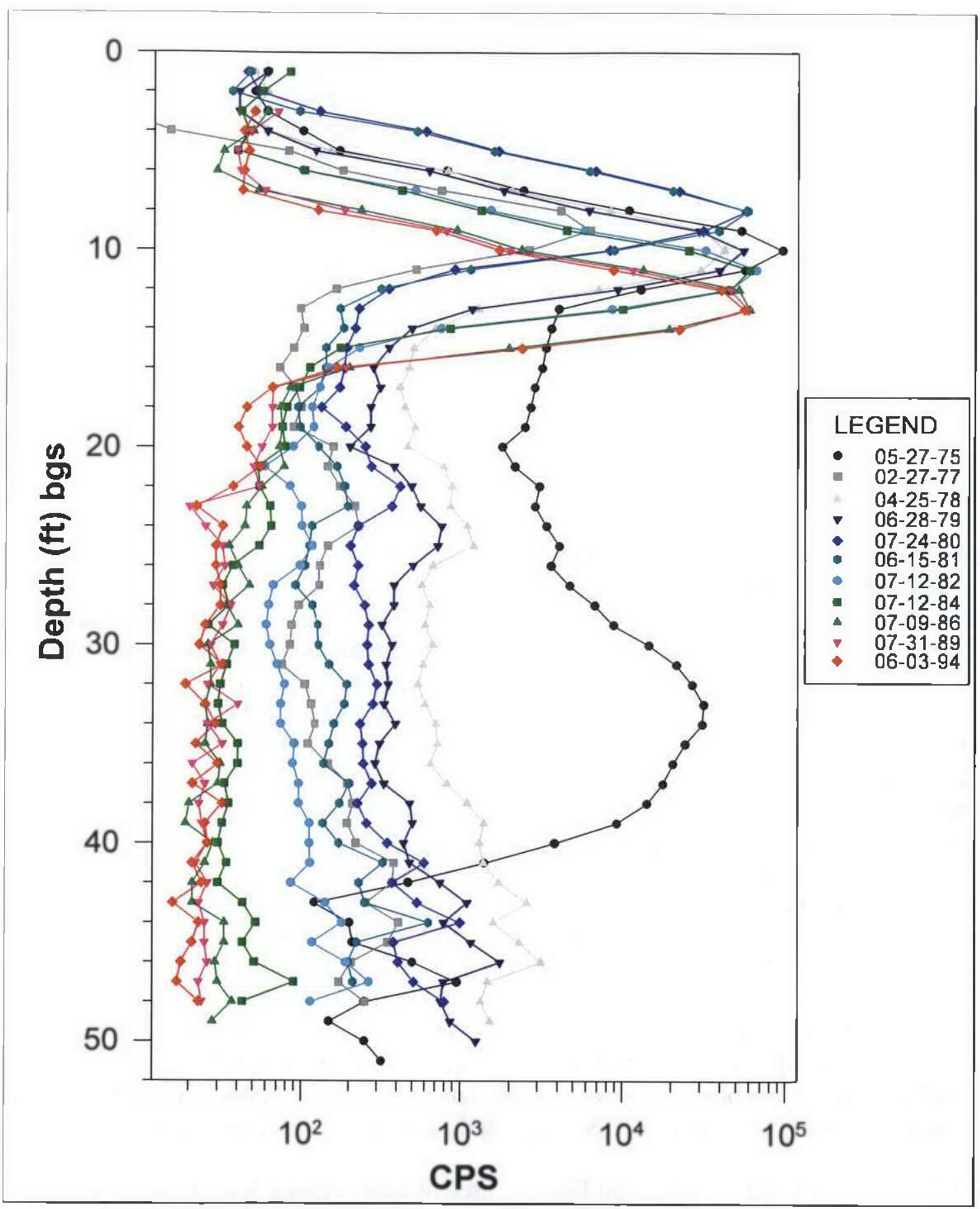


Figure 4-15 Gamma Logging Results for Drywells 11-02-01 thru 11-02-05
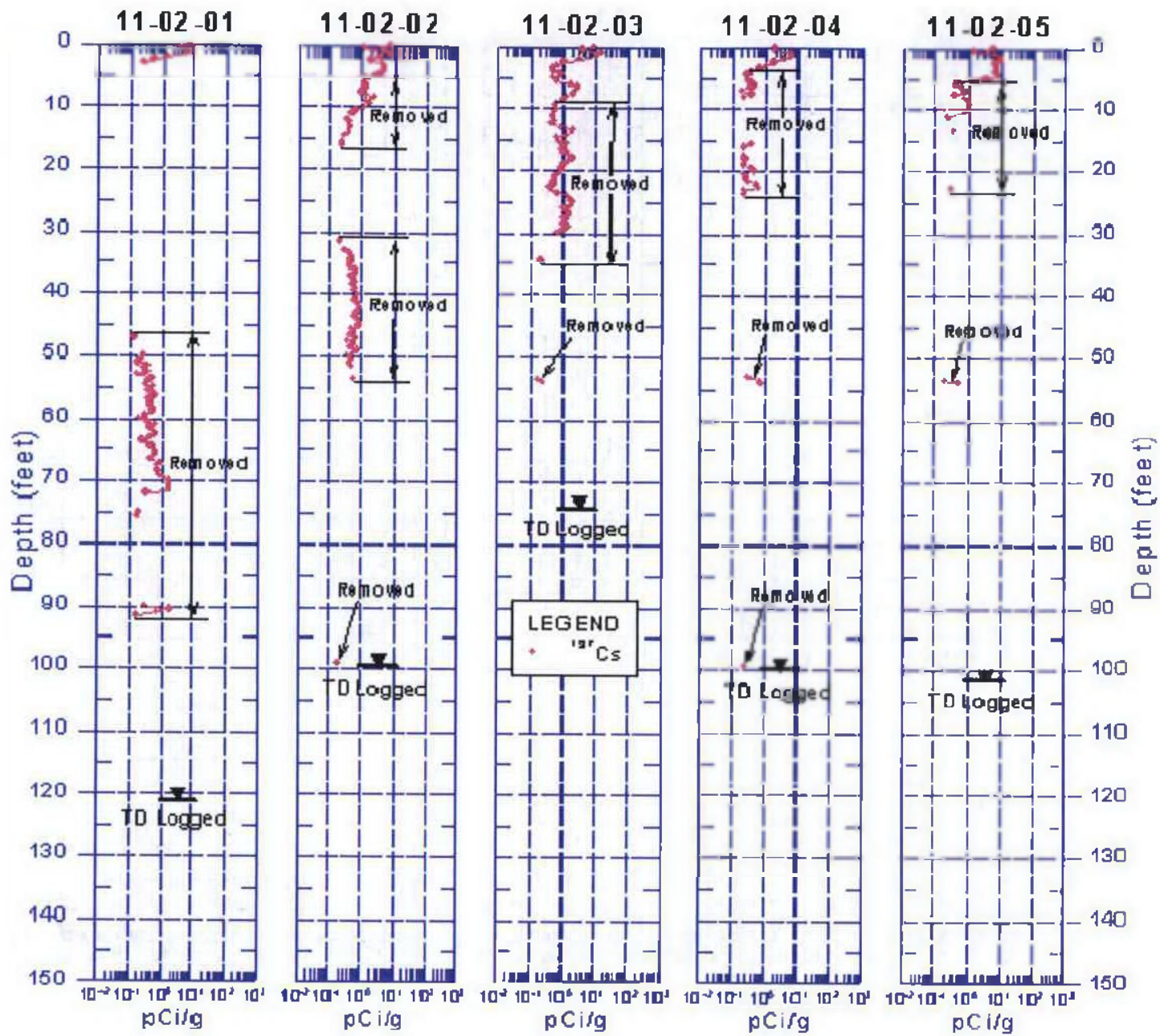
Figure 4-16 Gamma Logging Results for Drywells 11-02-01 thru 11-02-05
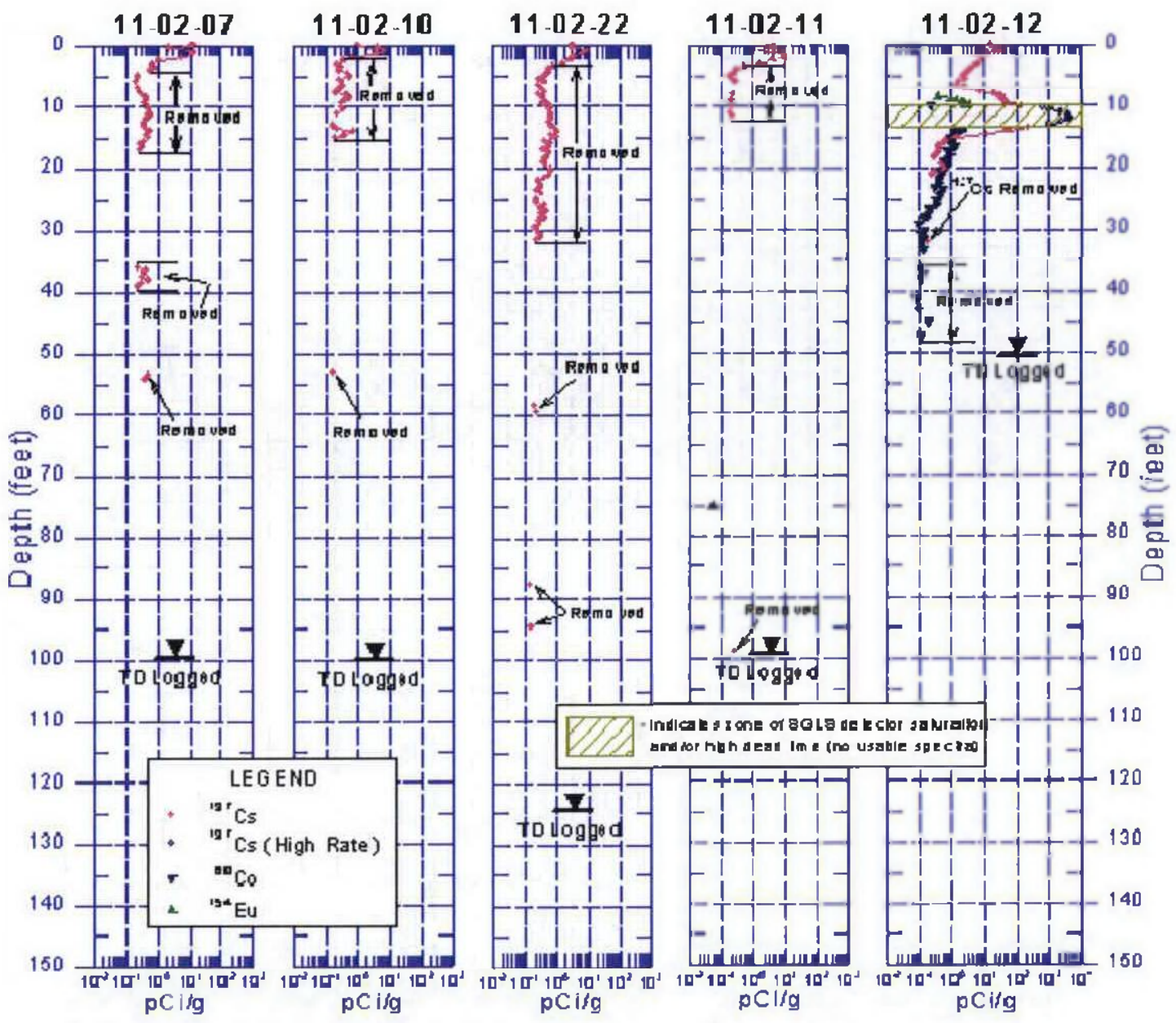
Figure 4-17 Repeated Gamma Logging for Drywell 11-02-12 (2 Sheets)

\section{B arehole 11-02-12}

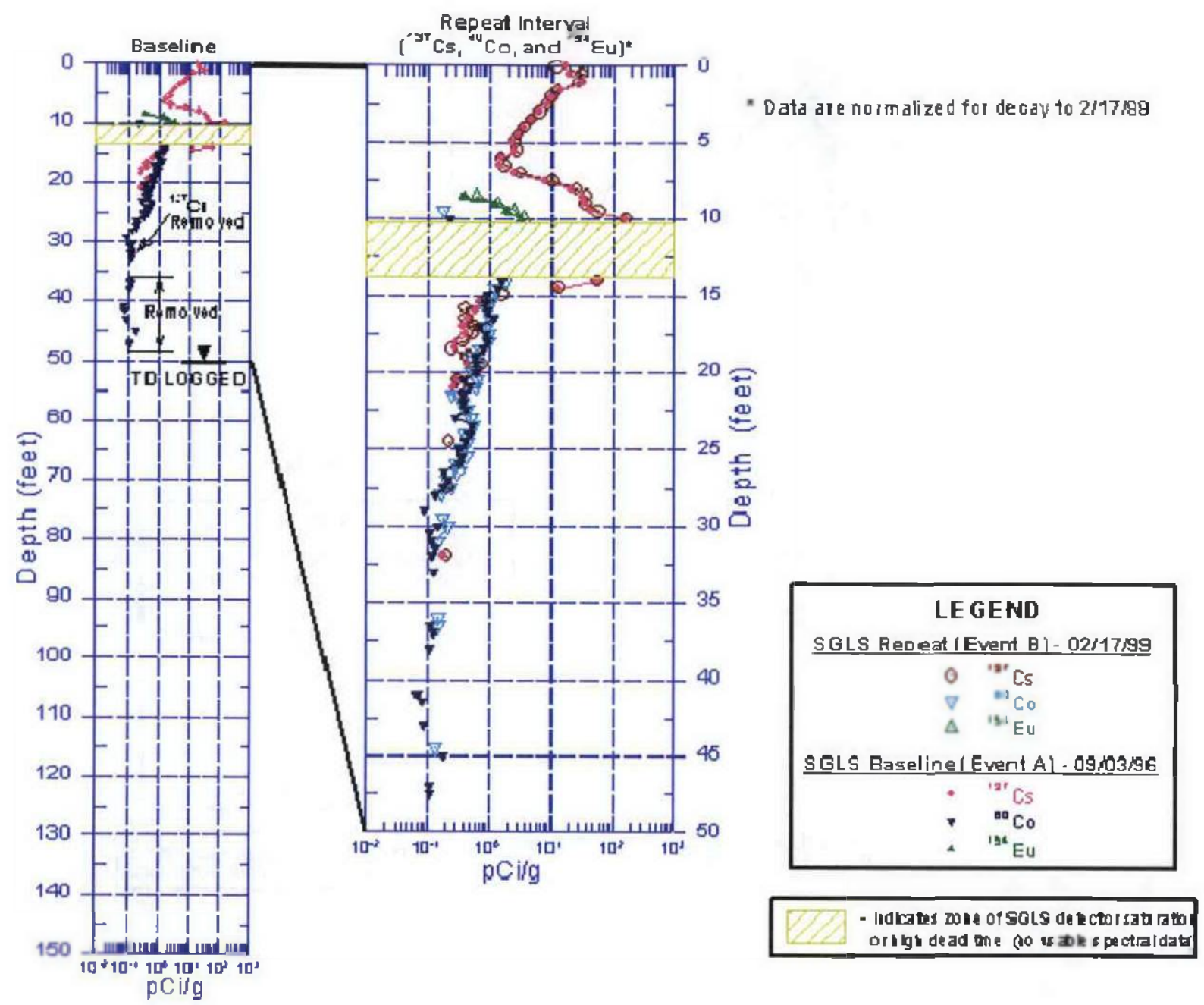




\section{Borehole 11.02.12}

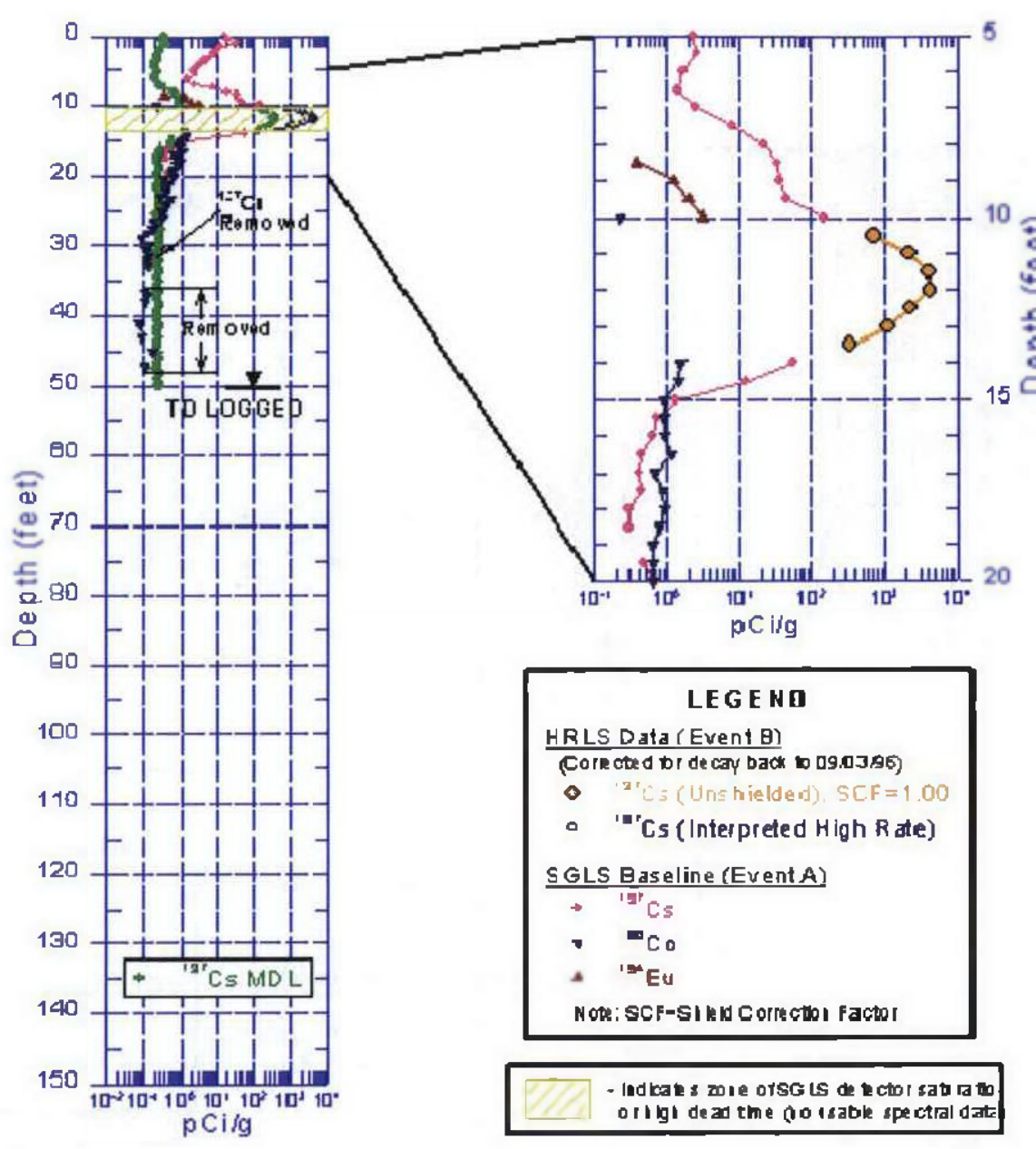

\subsubsection{AX-102 Conclusions}

The assessment team has determined the estimated waste loss of 3,400-gallons from tank $241-\mathrm{AX}-102$ is inconsistent with the relatively low level of radiation detected in the leak detection pit and drywells associated with this tank. The likely source of radioactivity detected historically in drywells 11-02-11 and 11-02-12 is the leaking Dresser coupling associated with the tank offgas piping rather than breach of the tank liner.

It is recommended that HNF-EP-0182 be revised to indicate there is no basis for assuming a leak loss volume or inventory for a tank AX-102. Therefore, no leak inventory was assigned. 


\subsection{Tank AX-104 Waste Loss Event}

\subsubsection{Tank AX-104 Operating Summary}

An operational timeline for single-shell tank (SST) AX-104 is provided in Figure 4-18 to aid in the following discussion. SST AX-104 originally received PUREX HLW from 1965 through 1969. Additionally, SST AX-104 received 37,000-gallons of B Plant waste in the third quarter of 1969. The tank was operated as a boiling waste tank to evaporate excess water and concentrate the PUREX HLW. The tank experienced a temperature excursion lasting from February 1970 through June 1970, reaching a maximum temperature of $233^{\circ} \mathrm{C}\left(\sim 451^{\circ} \mathrm{F}\right)$ in the sludge. The waste temperature was reduced by removal of supernate and addition of $65^{\circ} \mathrm{C}$ water.

The supernate was removed from SST AX-104 in 1972 for cesium ion exchange processing in the 221-B Plant. Tank AX-104 was then refilled from October 1972 through March 1973 with PUREX sludge supernate (PSS) from SST A-102 to allow entrained solids to settle before transferring the supernate to the 221-B Plant for cesium ion exchange processing. Tank AX-104 also received PSS from sluicing tank A-104 in September 1974 and PSS from sluicing tank A-103 in the second quarter of FY 1976.

The PSS was transferred from SST AX-104 in February 1977 for cesium ion exchange processing in the 221-B Plant and to prepare the tank for sluicing. The sludge in SST AX-104 was sluiced from March 31, 1977 through April 20, 1978. During sluicing, no increased radiation was reported to have been detected in the leak detection pit for SST AX-104.

The tank was classified as questionable integrity and removed from active service in August 1978 as a result of the radioactivity detected in drywell 11-04-08 (IDMS Accession \#293-006415). However, the source of the radioactivity detected in drywell 11-04-08 could not be determined. The strongest gamma radiation signal was detected due east, toward tank $\mathrm{AX}-104$, which led personnel in 1988 to suspect the integrity of the tank. The radioactivity detected in drywell 11-04-08 (60-72-ft bgs) was correlated to ruthenium-106 decay rate (RPP-8821 pages 18-21). No corresponding liquid level decline or elevated radiation readings were detected in the leak detection pit (see section 4.5.1) at the time increased radioactivity was detected in drywell 11-04-08. These operational periods for SST AX-104 are discussed further below. 
Figure 4-18 Tank AX-104 Operational Timeline (1965-1981)

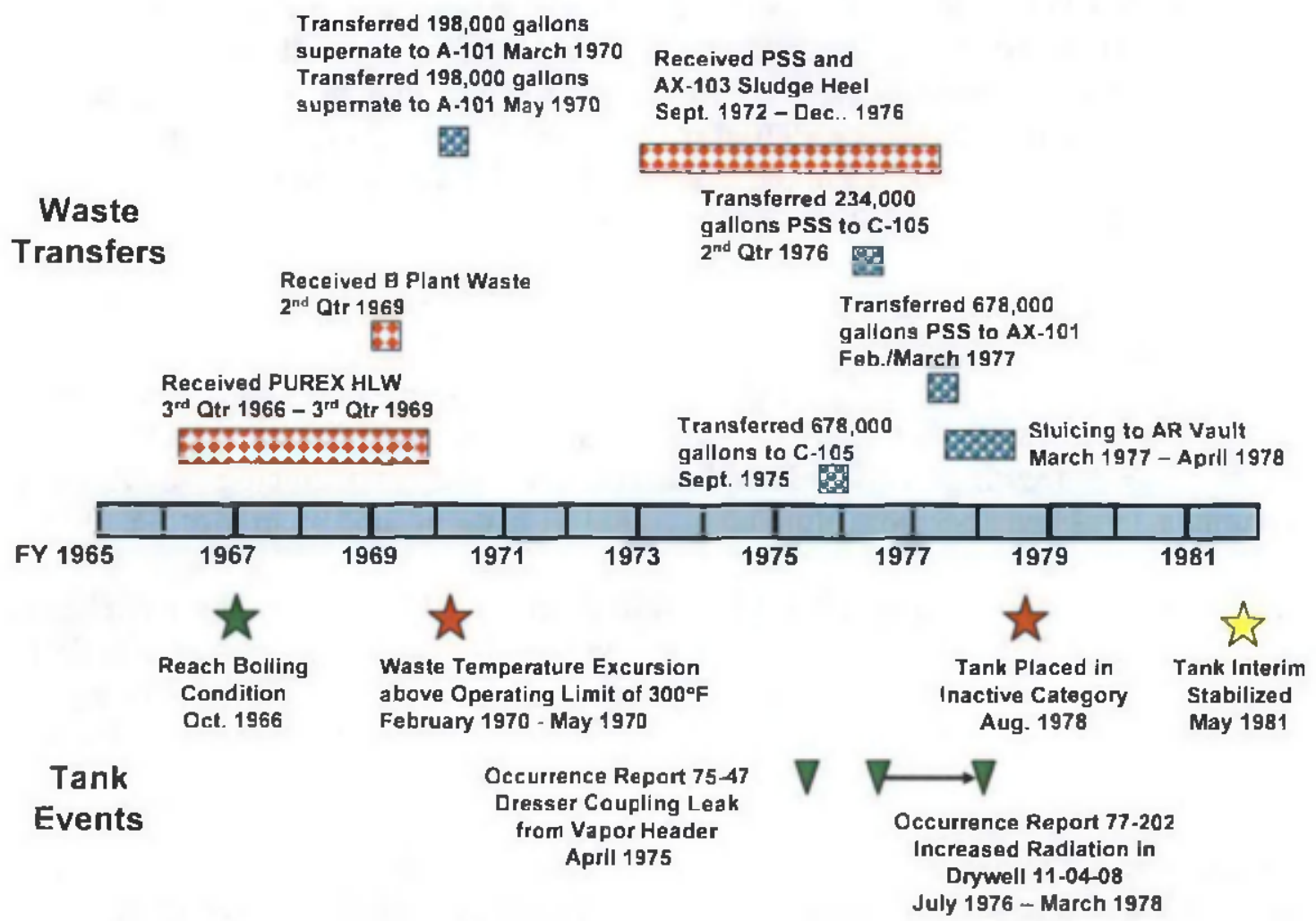

\subsubsection{Tank AX-104 Operating History}

PUREX HLW Receipt (1965 - 1969): Single-shell tank (SST) 241-AX-104 construction was completed in January 1965 (HAN-90650 page 16). Water was added to the tank in the fourth quarter of FY 1965 (RL-SEP-821 page 8) and the third quarter of FY 1966 (ISO-404 page 8). The water added to SST AX-104 was likely done as part of the preheating procedure. The standard practice employed for the 241-AX tanks was to add water and preheat the water prior to adding boiling waste from the PUREX plant. In the fourth quarter of 1966 , SST AX-104 began to receive HLW from the PUREX plant (ISO-538 page 8). Tank AX-104 continued to receive PUREX HLW through the third quarter of FY 1968 (ARH-721 page 9). Tank AX-104 was reported to have reached boiling conditions in October 1966 (RHO-CD-1172 page B-54 and ISO-674 page 2). Tank AX-104 continued to evaporate excess water due to the radiolytic decay heat, resulting in the removal of 2,042,000-gallons of condensate from October 1966 through the fourth quarter of FY 1968 (ARH-871 page 3). 
SST AX-104 also received 37,000-gallons of B Plant waste and 37,000-gallons of PUREX waste in the second quarter of FY 1969 (ARH-1200 A page 10) and an additional 3,000-gallons of PUREX waste in the third quarter of FY 1969 (ARH-1200 B page 10).

Waste Temperature Excursion: The waste temperature in SST AX-104 began to increase from $\sim 260^{\circ} \mathrm{F}$ in September 1969 to $\sim 340^{\circ} \mathrm{F}$ in May 1970 (RHO-CD-1172 page B-57), which is above the maximum operating limit of $300^{\circ} \mathrm{F}$. The waste temperature had been between 260 to $280^{\circ} \mathrm{F}$ for the 3-years. Air flow to the airlift circulators was adjusted and the temperature of the sludge was reduced in all but one location below the operating limit of $150^{\circ} \mathrm{C}\left(300^{\circ} \mathrm{F}\right)$; the eastern periphery of the tank reached $158^{\circ} \mathrm{C}\left(\sim 316^{\circ} \mathrm{F}\right)$ in February 1970 (PR-REPORT FEB70 page AV-3). Since the tank was maintained at maximum operating volume, no attempt was made to dilute the contents.

In an effort to reduce the waste sludge temperature, approximately 198,000 -gallons of supernate were transferred from SST AX-104 to A-101 on March 18, 1970 and 198,000gallons of water at $65^{\circ} \mathrm{C}$ were added to SST AX-104 (PR-REPORT MAR70 page AIV-5, PR-REPORT MAY70 page AIV-6 and ARH-1666 A page 10). "This action became necessary when the increasing localized temperatures in the outer periphery of the tank did not respond to a remedial treatment of varying the air flow to the nearby airlift circulators and a slight dilution of the tank contents to the maximum operating temperature. The maximum temperature in the tank had reached $213^{\circ} \mathrm{C}\left(\sim 415^{\circ} \mathrm{F}\right)$ when the transfer was initiated. This temperature was increasing at a rate of $2^{\circ}$ to $3^{\circ} \mathrm{C}$ per day. Two other peripheral temperatures also exceeded the operational limit of $150^{\circ} \mathrm{C}$. The localized hot spots near the tank sidewall have not caused the sidewall differential temperatures to exceed the operational limit of $17^{\circ} \mathrm{C}$ per foot of concrete" (PR-REPORT MAR70 page AIV-5). Since the sidewall differential temperatures had not exceeded the operational limit of $17^{\circ} \mathrm{C}$ per foot of concrete, cracking of the concrete was unlikely to have occurred.

The maximum temperature in the $\mathrm{AX}-104$ sludge continued to rise after the dilution and reached a maximum of $225^{\circ} \mathrm{C}\left(\sim 437^{\circ} \mathrm{F}\right)$, but then began to decrease in April 1970 (PRREPORT APR70 page AIV-5). The sludge temperature then began to increase again and reached $233^{\circ} \mathrm{C}\left(\sim 451^{\circ} \mathrm{F}\right)$ in the western sector of the tank periphery in May 1970 (PRREPORT MAY70 page AIV-6). This prompted transfer of an additional 198,000-gallon of supernate ( $20 \%$ of total) from SST AX-104 to A-101 and 195,000-gallons of water at $65^{\circ} \mathrm{C}$ were added to SST AX-104 to reduce the sludge temperature (PR-REPORT MAY70 page AIV-6 and ARH-1666 B page 10). The calculated sodium molarity in SST $\mathrm{AX}-104$ was only $3 \mathrm{M}$ following this transfer. "The maximum temperature across the concrete wall of the tank exceeded the recommended operational limit of 25 by $6^{\circ} \mathrm{C}$. This differential temperature is measured in the vicinity of the lowest periphery sludge temperature $\left(156^{\circ} \mathrm{C}\right)$ " (PR-REPORT MAY70 page AIV-6). Excessive differential temperatures across the concrete wall of the tank can lead to cracking of the concrete.

This last dilution of tank $\mathrm{AX}-104$ resulted in the downward trend in tank temperature. The tank contents were maintained at approximately 363 -inches ( 1 million gallons) to 
avoid overly concentrating the supernate and causing further precipitation PR-REPORT JUN70 page AIV-5). No additional waste or water additions to SST AX-104 were reported again until September 1972.

PUREX Sludge Supernate Receipt (1972 - 1976): In September 1972, 678,000-gallons of supernate were transferred from SST AX-104 to AX-103 and then to C-105 for cesium ion exchange processing in the 221-B Plant (PPD-493-9-DEL page AIV-13 and ARH$2456 \mathrm{C}$ page 9). This transfer was conducted to ready SST AX-104 to receive the PUREX sludge supernate (PSS) from sluicing SST A-102 (PPD-493-9-DEI page AIV17). From October 1972 through March 1973, approximately 843,000-gallons of PSS were transferred from 244-AR Vault to SST A-104 and then to SST AX-104 to allow entrained solids to settle (ARH-2456 D page 9 and ARH-2794 A page 9). From October 1972 through June 1973, approximately 878,000-gallons of PSS were transferred from SST AX-104 to AX-103 and then to SST C-105 for eventual cesium ion exchange processing in the 221-B Plant (ARH-2456 D page 9, ARH-2794 A page 9, and ARH2794 B page 9).

Tank AX-104 again received PSS in September 1974. Tank AX-104 received 146,000-gallons of water and 446,000-gallons of PSS via 244-AR Vault from sluicing of SST A-104, filling the tank to $\sim 763,000$-gallons (ARH-CD-133 C page 9). The supernate slowly evaporated from September 1974 through March 1975, reducing to approximately 504,000-gallon, including an estimated 44,000-gallon of sludge (ARH-CD-702 A page 9).

SST AX-104 received 29,000-gallons and 9,000-gallons of PSS from sluicing SST AX103 and 244-AR vault, respectively in the second quarter of FY 1976 (ARH-CD-702 A page 9). Approximately 234,000-gallons of PSS were transferred to SST C-105 for staging to the cesium ion exchange process in the 221-B Plant in the second quarter of FY 1976. Tank AX-104 again received PSS from sluicing SST AX-103 in September 1976 (ARH-LD-221 B page 12), October 1976 (ARH-LD-222 B page 13), and November 1976 (ARH-LD-223 B page 11). Then, the heel in SST AX-103 was sluiced to SST AX-104 in December 1976 (ARH-L.D-224 B page 11).

Sluicing (1977 - 1978): On February 25, 1977 through March 3, 1977, the supernate in tank AX-104 was transferred to SST AX-101 ( 771,400-gallons) in preparation for sluicing (OR-77-36). Sluicing of the SST AX-104 sludge was initiated on March 31 , 1977 to make this tank available for receipt of 242-A Evaporator bottoms (ARH-LD-227 $B$ page 27). The AX-104 sludge was easily sluiced to 244-AR Vault, but the sludge proved difficult to process due to its highly insoluble nature. More than three-fourths of the sludge was stated as being insoluble in nitric acid (ARH-LD-229 B page 31).

Sluicing the AX-104 sludge was conducted every month except for October from March 31, 1977 through November 5, 1977 and from March 2, 1978 through April 20, 1978 (IDMS Accession \#D194052912).

Following completion of sluicing, the residual sludge in tank AX-104 was photographed and a map of the tank bottom made in July 1978 showing sludge location was prepared 
(IDMS Accession \#D193015327). The sludge in tank AX-104 is unevenly distributed and the estimated volume is 7,000-gallons (HNF-EP-0182, rev. 237).

"As part of Rockwell Hanford Operation's efforts to remove all single-shell tanks from active service, Tank 104-AX was recently placed into the inactive category" in August 1978. Tank AX-104 remained connected to the 702-A vessel ventilation to cool the tank contents. Also as of August 1978, "Four drain lines from AX-Farm pits and cleanout boxes are presently routed to the tank" (IDMS Accession \#D194032070).

Interim Stabilization (1981): Tank AX-104 was declared interim stabilized effective August 10, 1981 based on review of in-tank photographs obtained on May 14, 1981 (HNF-SD-RE-TI-178, rev. 9 page 32). No supernate was estimated to be present in the tank. The four, valve and service pit drain lines connecting to the tank were removed during August 1981 to prevent water intrusion (HNF-SD-RE-T1-178, rev. 9 page 32). The in-tank photographs were observed to "... show a series of corrugation ridges in the tank bottom liner and no discernable liquid pools. There is no definable pattern to this buckling configuration. In addition, areas of mounded dry sludge are seen at random locations about the tank" (HNF-SD-RE-TI-178, rev. 9 page 32). However, a tank composite photograph taken in August 11, 1987 (Figure 4-19) does not show the reported ridges or tank bottom buckling pattern. The entire tank bottom is visible in the August 11,1987 photograph, which shows weld plates for the airlift circulators and a small amount of sludge and a sludge swirl pattern. 
Figure 4-19 Composite Photograph of Tank AX-104 (August 11, 1987)

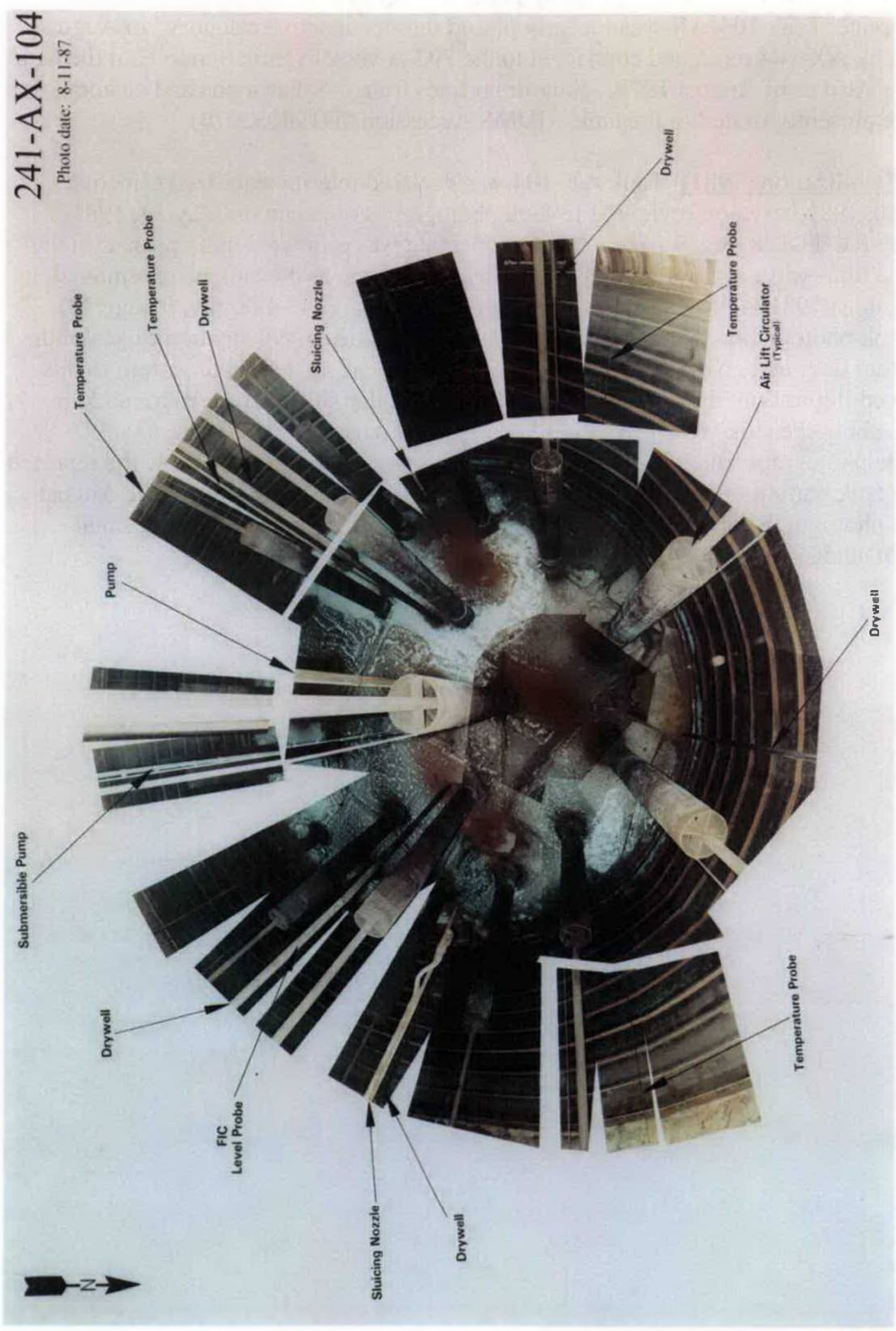


Off-gas Vapor Header Dresser Coupling Leak (1975): Dresser couplings provide a compression seal on the outer surface of vapor header piping segments that are $\sim 25$ - $\mathrm{ft}$ in length. The couplings provide for expansion and contraction of the vapor header pipe segments. Highly contaminated soil was detected at a depth of 10 -feet adjacent the Dresser coupling (see discussion on Tank Design Features) joining the 20-inch vapor header from SST AX-102 to the main 24-inch header and the Dresser coupling atop SST AX-104 (ARH-CD-587). Drywell 11-04-01, installed in January 1975, had contamination at 24-ft bgs when first monitored in January 20, 1975. Drywell 11-04-11, installed in January 1975 , had contamination at $25-\mathrm{ft}$ through $60-\mathrm{ft}$ bgs (well bottom) when first monitored in January 20,1975. The contamination in both drywells did not show signs of migration to lower depths, but did show signs of radioactivity decay. Neither tank liquid level nor leak detection pit liquid level or radiation monitor gave any indication of waste leakage from the tank based on data review for March 20, 1974 through June 29,1975 . The contamination was attributed to a Dresser coupling leak (IDMS Accession \#D194052992).

ARHCO personnel conducted a field test to repair the vapor header by injecting a sealant around the Dresser couplings for SST AX-102 (ARH-CD-587). However, the effectiveness of the sealant was inconclusive and migration of contamination from the vapor header continued. ARHCO personnel reported the results of the 241-AX vapor header sealant test to the U.S. Energy Research and Development Administration and recommended that normal operations continue in the 241-AX farm, using continued dry well monitoring to "... provide assurance that any further vapor header leakage will be detected (IDMS Accession \#D195006631).

The Dresser coupling joining SST AX-104 to the main vapor header showed continued signs of leakage, as reported in January and April 1976 (OR-76-08 and OR-76-59). In January 1976, drywell 11-04-01 experienced an increase in radiation detected at a depth of $32-\mathrm{ft} \mathrm{bgs,} \mathrm{with} \mathrm{a} \mathrm{receding} \mathrm{of} \mathrm{the} \mathrm{peak} \mathrm{first} \mathrm{detected} \mathrm{in} \mathrm{January} 1975$ at a depth of $25-\mathrm{ft}$ bgs. High soil moisture content was attributed to the cause for the downward migration of contamination. In April 1976, drywell 11-04-01 experienced increase in radiation detected at a depth of 33-ft bgs, fluctuating from 2,000 to 2,700 counts per second (cps). This increase was attributed to high soil moisture content and the "... continuation of the dispersion of radioactive contamination which has leaked to the ground from the exhaust header which is located at a depth of ten feet and approximately 10-15 feet from the dry well" (OR-76-59). The radiation detected in drywell 11-04-01 and 11-04-11 continued to diminish in peak count per second.

\subsubsection{Tank AX-104 Waste Loss Estimate}

No increase in radiation was detected in the AX-104 leak detection pit or drywells associated with this tank that was attributed to a tank leak. However, drywell 11-04-08 was obscrved in November 1977 to have an increase in radiation above background reaching a peak of $247 \mathrm{cps}$ at $64-\mathrm{ft}$ bgs. The increase in radiation began in May 1976, but did not exceed background levels until August 1976. The radioactivity in this drywell had decreased to $204 \mathrm{cps}$ on March 8, 1978, but then began to increase again reaching 287 cps on April 19, 1978 (IDMS Accession \#293-006415). SST AX-104 was receiving 
PSS solution and sludge from final cleanout of SST AX-103 during the second quarter of FY 1976 through December 1976 and was actively being sluiced from March 31, 1977 through November 5, 1977 and March 2, 1978 through April 20, 1978.

A new drywell, 11-04-19, was installed in March 1978 to further investigate the potential for tank AX-104 to have leaked waste. Drywell 11-04-19 is situated between drywells 11-04-08 and 11-04-07 and is closer to tank AX-104. Initially, the radioactivity detected in drywell 11-04-19 was less than the detection limit of $50 \mathrm{cps}$ (SD-WM-TI-356 page 1104-10). RPP-8821 page 40 shows that the radioactivity detected in drywell 11-04-19 reached a maximum of $\sim 200 \mathrm{cps} 1978$ and then slowly decreased. The radioactivity detected in drywell 11-04-08 was subsequently correlated to ruthenium-106 decay rate (RPP-8821 pages 36-40).

The cause for the increased radiation detected in drywell 11-04-08 could not be determined. The strongest source of the radiation detected in drywell 11-04-08 was determined to be due east, toward tank AX-104. The radioactivity detected in drywell 11-04-08 was subsequently correlated to ruthenium-106 decay rate (RPP-8821 pages 1821). The tank was classified as questionable integrity and removed from active service in August 1978 as a result of the radioactivity detected in drywell 11-04-08 (IDMS Accession \#293-006415).

Drywells nearby SST AX-104 currently do not show any significant contamination associated with a tank leak, as shown in Figure 4-20 (GJO-97-14-TAR, GJO-HAN-12). The activity detected in drywells 11-04-08 and 11-04-19 show no signs of contamination from a tank waste leak. Migration of Cs-137 contamination down the inside or outside of the drywell casing is suspected to have affected the distribution of some of the contamination detected in the drywells. Much of the bias of the drywell log data that is due to drywell migration effects was removed from the surveys and is designated as "removed" in Figure 4-20.

In an attempt to quantify the potential waste loss, Rockwell Hanford Operations personnel averaged the waste loss for 18 other SSTs that had not shown a catastrophic leak (i.e. excluded tanks T-106 and A-105). The average waste loss for these 18 SSTs is 8,000 -gallons. The estimated waste loss from tank 241 -AX-104 was assigned 8,000gallons in HNF-EP-0182 based solely on the average waste loss from 18 other SSTs for which liquid level decline was reported (Baumhardt 1989). 
Figure 4-20 Spectral Gamma Log Data from AX-104 Drywells
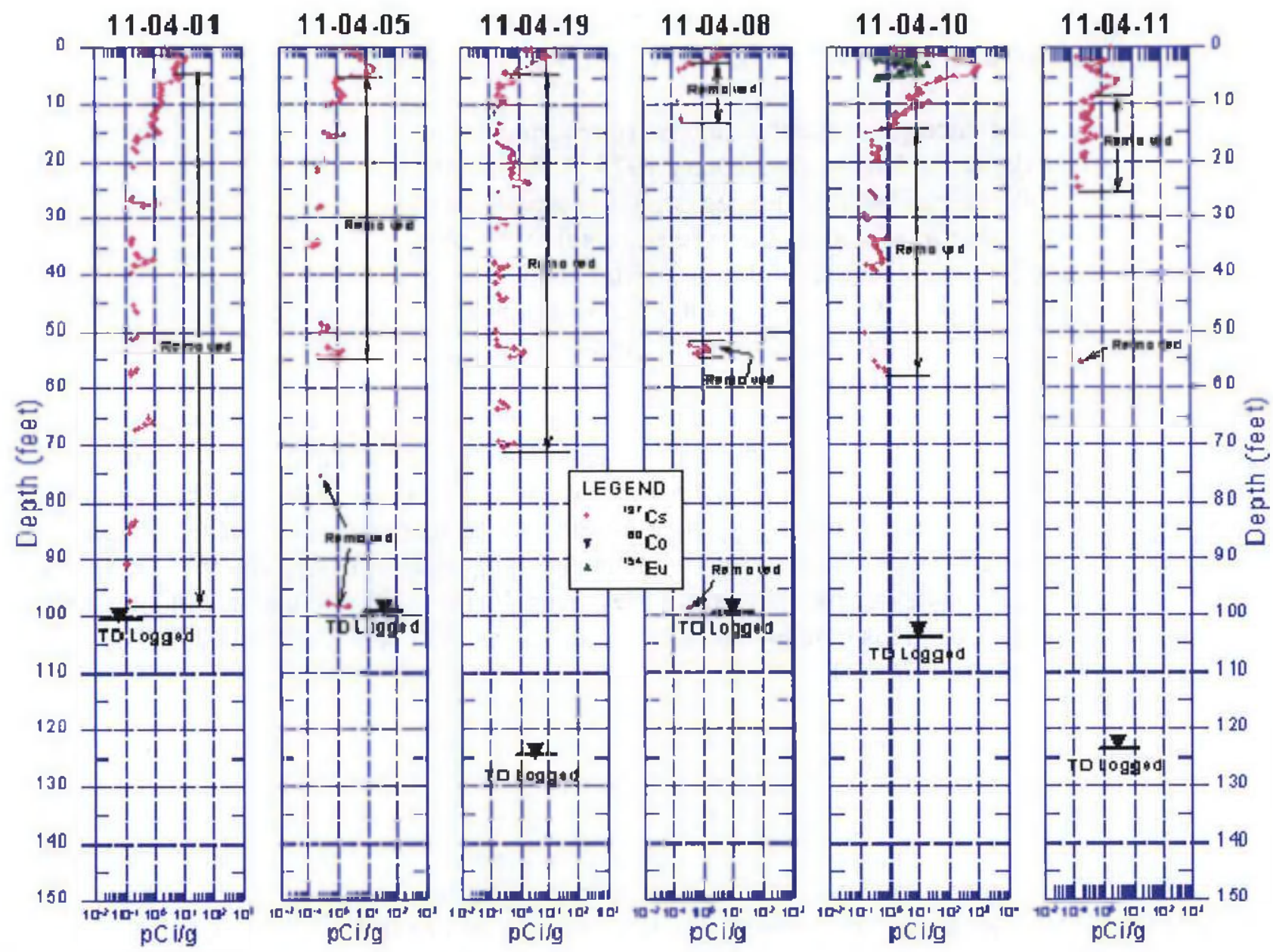
The Field Investigation Report for Waste Management Areas $C$ and $A-A X$ (RPP-35484) did not conduct specific characterization activities around tank AX-104. RPP-35484 states the primary indication of tank waste loss began in April 1975, when an increase in gross gamma levels at 40-ft bgs were first noticed at drywell 11-04-11, which was installed in January 1975. The following three paragraphs are taken from RPP-35484.

Elevated gross gamma levels are reported in the first measurements taken at drywell 11-04-11 in January $1975(1,490 \mathrm{c} / \mathrm{s}$ at $25 \mathrm{ft} \mathrm{bgs,} 255 \mathrm{c} / \mathrm{s}$ at $39 \mathrm{ft} \mathrm{bgs}$, and $950 \mathrm{c} / \mathrm{s}$ at $64 \mathrm{ft} \mathrm{bgs}$ ), suggesting the presence of pre-existing contamination. The higher level counts diminished rapidly thereafter to near detection limit levels by late 1978 (Figure 4-21). A similar profile was also observed at nearby drywell 11-04-01 (Figure 4-22). In this drywell, maximum levels were found in one depth interval between 15 and $40 \mathrm{ft}$ bgs, and maximum values of nearly $8,000 \mathrm{c} / \mathrm{s}$ suggest that this drywell was closer to the source of leakage. Given the relatively rapid decrease in gross gamma levels shown in Figure 4-21 and Figure 4-22, shorter-lived radionuclides (e.g., ruthenium-106) are likely the primary radiation producers. Recent spectral gamma analyses show only measurable $\mathrm{Cs}^{1.37}$ concentration near the surface, which may be related to these losses or some other near-surface release. As with tank AX-102, analysts concluded that the source of this waste release was part of the buried 20 -in. vapor line and vessel vent header system. [This conclusion is based on information presented in IDMS Accession \#D194052992.]

Two other drywells indicated elevated gross gamma contamination around tank AX-104. In drywell 11-04-08, elevated gross gamma measurements (up to $350 \mathrm{c} / \mathrm{s}$ ) were taken in 1977 and 1978 between 60 and $65 \mathrm{ft}$ bgs. A reduction by half within a year's time suggests that ruthenium-106 was the primary contributor. Whether this observation indicates a continuation of waste migration from the same source affecting drywells 11-04-01 and 11-04-11 is not clear, though the timing and radiation levels are consistent with that hypothesis. On the other hand, no indications of elevated gross gamma activity were observed at drywell 11-04-10, which is located between drywell 11-04-08 and the other drywells. A migration path that bypassed drywell 11-04-10 appears problematic. Drywell 11-04-10 is also notable for an apparently independent near-surface waste loss. Unlike the other drywells around tank AX-104, mid 1990s spectral gamma data analyses show $\mathrm{Cs}^{137}$ peaks at approximately $5 \mathrm{ft}$ bgs, accompanied by cobalt-60 and europium-154 peaks in the same location.

Tank AX-104 was identified as having questionable integrity in 1977 and assumed a leaker of 8,000 gal because of vapor system losses in 1988. No reports are available that explain the questionable integrity designation, nor is the information used to determine the leak volume estimate of 8,000 gal given in past assessments. 
It should be noted that the questionable integrity designation for tank AX-104 is a result of the radioactivity detected in drywell 11-04-08 (IDMS Accession \#293-006415), as previously discussed.

Figure 4-21 Historical Gross Gamma Log Data from Drywell 110411

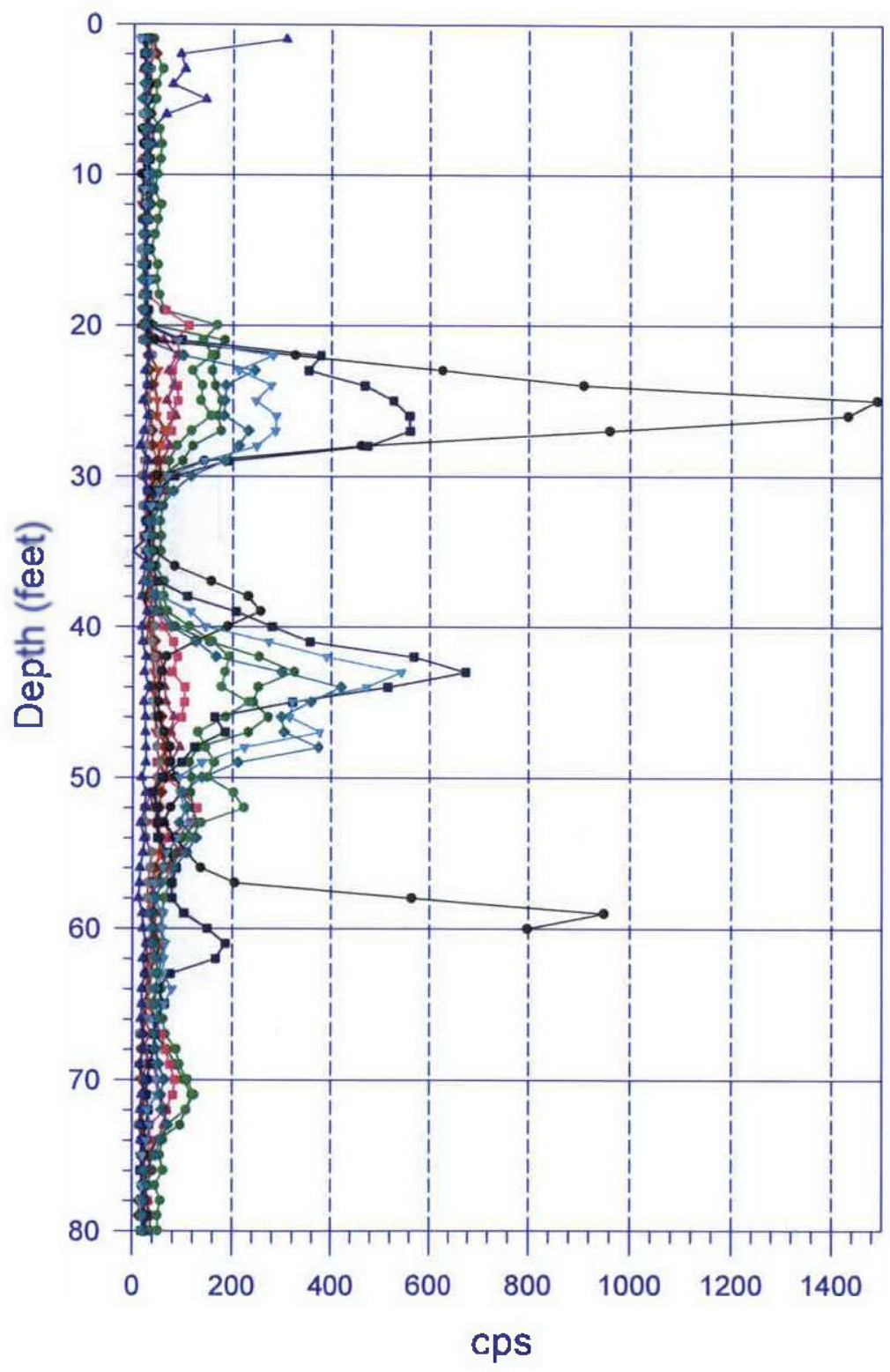


Figure 4-22 Historical Gross Gamma Log Data from Drywell 110401

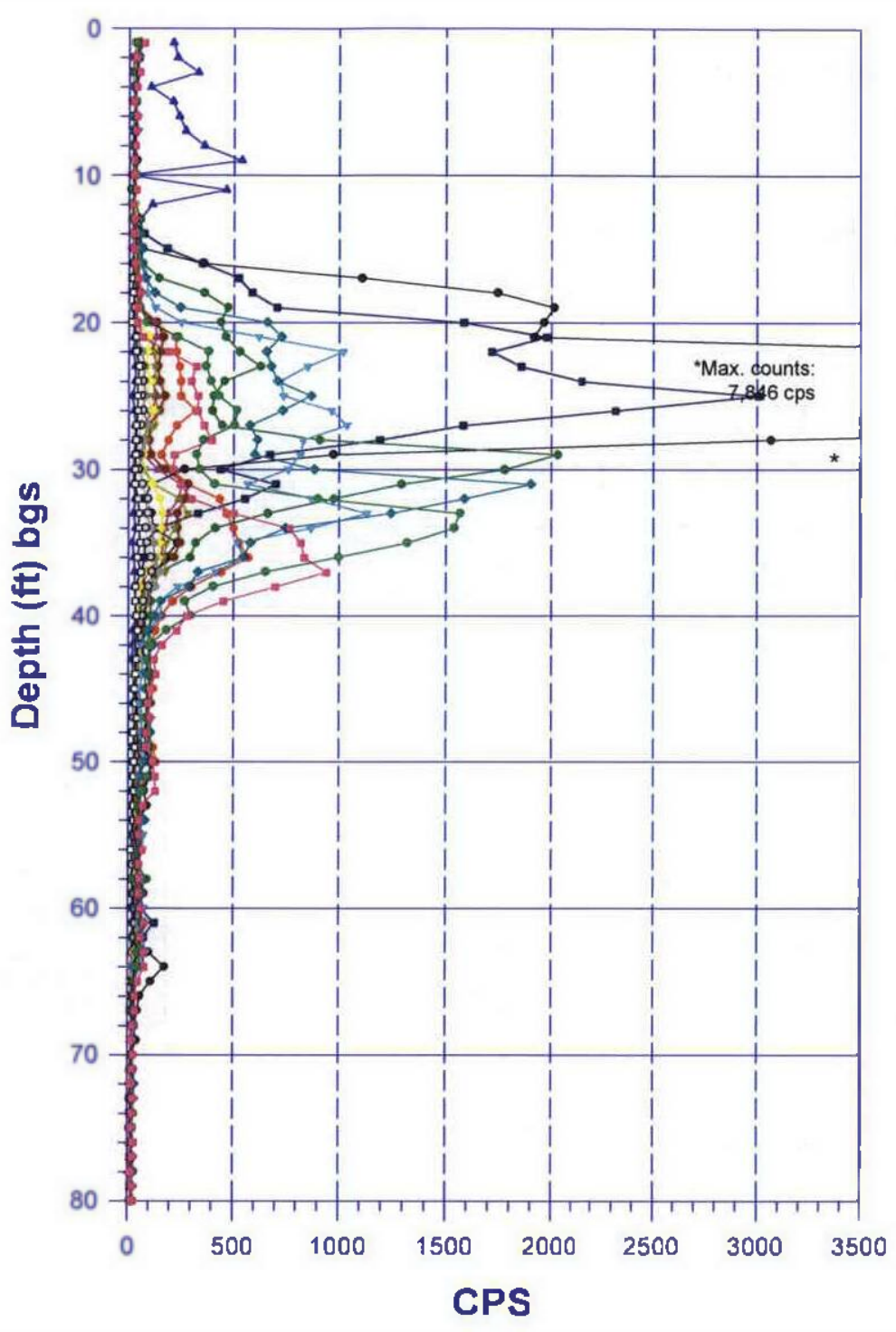




\subsubsection{AX-104 Conclusions}

The assessment team deems using the average waste loss for 18 other SSTs that had not shown a catastrophic leak (i.e. excluded tanks T-106 and A-105) as a method of estimating the waste loss from tank $241-\mathrm{AX}-104$ is not valid for the purposes of establishing a waste loss inventory and volume. It is doubtful that PSS waste actually leaked from tank 241-AX-104, since the leak detection pit and drywells associated with this tank do not show the level of radiation that is normally associated with a tank waste loss. The likely source of radioactivity detected historically in drywells 11-04-01 and 1104-11 is the leaking Dresser coupling associated with the tank offgas piping. The source of the historical ${ }^{106} \mathrm{Ru}$ radioactivity detected in drywells 11-04-08 and 11-04-19 can not be definitively determined, but could be from migration of contamination associated with the Dresser coupling leaks in this tank farm or nearby condensate lines which may have leaked. Ruthenium is known to readily migrate through Hanford soils.

It is recommended that HNF-EP-0182 be revised to indicate the waste loss volume is indeterminate.

\subsection{Unplanned Waste Releases}

Information is provided on unplanned releases (UPRs) of tank wastes from pipelines, diversion boxes, and other structures (i.e., ancillary equipment) within the Waste Management Area (WMA) A and AX at the Hanford Site. The WMA A and AX encompasses the 241-A and 241-AX Tank Farms, which includes ten 1,000,000 gallon capacity single-shell tanks (SSTs); diversion boxes 241-A-152, 241-AY-152, 3; transfer box 241-A-153; diverter station 241-AX-152; valve pits 241-A-A, 241-A-B, 241-AX-A, 241-AX-B, 241-AX-01VP, 241-AX-02VP, 241-AX-03VP, 241-AX-04VP, 241-A-501, 241-AY-501, and 241-AX-501; miscellaneous underground storage tanks 241-A-350, 241-A-433, and 241-A-417; ventilation building 241-A-431, compressor building 241-A701, fan house 241-A-702, control room / change houses 241-A-271 and 2707-EB, condenser building 241-A-401, 241-AX-801A and 241-AX-801B instrument building. Additionally, there is an underground vapor header, seal pots, condensers, and deentrainment vessels that were used as part of the primary ventilation system for the 241-A and 241-AX tanks. Section 4.8.1 discusses known UPRs and discusses available documentation. Section 4.8.2 provides information on potential tank waste losses from pipelines. 
Information on unplanned releases (UPRs) in the WMA A and WMA AX was collected from the following sources:

- DOE/RI-88-30, rev. 16, 2007, Hanford Site Waste Management Units Report, Fluor, Richland WA

- RPP-35484, Field Investigation Report for Waste Management Areas $C$ and A$A X$, M. P. Connelly, CH2M HILL Hanford Group Inc., Richland WA

- RPP-7494, 2001, Historical Vadose Zone Contamination from A, AX, and C Tank Farm Operations, Fluor Federal Services, Richland WA

- RPP-25113, 2005, Residual Waste Inventories in the Plugged and Abandoned Pipelines at the Hanford Site, CH2MHILL Hanford Company, Richland WA

- RPP-RPT-29191, 2006, Supplemental Information Hanford Tank Waste Leaks, CH2MHILI. Hanford Company, Richland WA

- Waste status summary and monthly report for the Hanford site from January 1945 through December 1980 (various reports)

- RHO-CD-673, 1979, Handhook 200 Areas Waste Sites, Rockwell Hanford Operations, Richland WA

The information provided on each UPR consists of the date when the waste loss event occurred, the waste type and estimate of the volume of waste discharged, if known.

\subsubsection{Identified UPRs}

DOE/RL-88-30, rev. 16, 2007, Hanford Site Waste Management Units Report, contains the official listing of unplanned releases identified at the Hanford site. Information on the UPRs associated with WMA A and WMA AX is summarized in Table 4-5. No new information other than that already listed in DOE/RL-88-30 was located on these UPRs.

\subsubsection{Suspect Pipeline Waste Loss Events}

Several pipelines in the WMA A and WMA AX are known to have failed while transferring tank wastes, as identified in Table 4-6. The date the failure was detected, the waste type and the volume of waste that was leaked to the soil (if known) are listed in Table 4-6. Unplanned releases (UPRs) have not been identified in DOE/RL-88-30, revision 16 for the failed pipelines listed in Table 4-6. In general, these pipeline leaks were either small volumes of waste (less than 20 gallons) or the leaked waste type was condensate. If a significant volume of condensate was leaked, this could cause migration of contaminated from other leak sites. The inventory of radionuclides and contaminants in these leaks would be insignificant in comparison with the estimated inventories from tank waste leaks in the $\mathrm{A}$ and $\mathrm{AX}$ tank farms. A separate program has been developed to examine the residual waste that may be present in pipelines or have leaked from failed pipelines as part of investigations for waste management area 200-IS-1. 


\section{RPP-ENV-37956 Rev. 1}

\begin{tabular}{|c|c|c|c|}
\hline \multicolumn{4}{|c|}{ Table 4-5 241-A and 241-AX Unplanned Release Sites (Excludes suspected tank leaks) } \\
\hline $\begin{array}{c}\text { UPR } \\
\text { Designation }\end{array}$ & Location & Description & Status \\
\hline UPR-200-E-18 & $\begin{array}{l}\text { Site is the 216-A-8 Sampler } \\
\text { Pit which is located } 100-\mathrm{ft} \text { to } \\
\text { the east of building } 241-\mathrm{A}- \\
271 \text {, outside of the } 241-\mathrm{A} \\
\text { Tank Farm at approximate } \\
\text { coordinates N136095, } \\
\text { E575450 (Washington state } \\
\text { coordinates). }\end{array}$ & $\begin{array}{l}\text { 1959: Fission product contamination has seeped into } \\
\text { the ground around the edges of the concrete pad } \\
\text { contaminating it on the soil surface. The } \\
\text { contamination is from moisture dripping from the vent } \\
\text { pipe bonnet. This pit is located } 100 \text { feet east of } 241-\mathrm{A}- \\
271 \text { building at coordinates N- } 42340 \text {, W- } 42340 \\
\text { [Hanford coordinate system], marked with stake, chain } \\
\text { and radiation zone signs" (HW- } 60807 \text { page } 18 \text { ). } \\
\text { Waste type was process condensate from } 241 \text {-A Tank } \\
\text { Farms. }\end{array}$ & $\begin{array}{l}\text { Placards denote underground } \\
\text { contamination source. }\end{array}$ \\
\hline UPR-200-E-42 & $\begin{array}{l}\text { Site is the } 241-\mathrm{AX}-151 \\
\text { diverter station, which is } \\
\text { located outside of the } 241-\mathrm{A} \\
\text { and } 241-\mathrm{AX} \text { Tank Farms near } \\
\text { the comer of } 4^{\text {th }} \text { Street and } \\
\text { Buffalo Avenue. }\end{array}$ & $\begin{array}{l}\text { November 6, 1972: Surveys made at the } 241-\mathrm{AX}-151 \\
\text { diverter station on November } 6,1972 \text { revealed direct } \\
\text { and smearable contamination of } 200 \text { to } 300 \text { millirad per } \\
\text { hour with a few spots in excess of } 5 \text { rad per hour. The } \\
\text { green tape covering the cover blocks cracks was } \\
\text { contaminated to } 20 \text { rad per hour. The green tape } \\
\text { sealing the cover block cracks was contaminated to } 20 \\
\text { rad per hour. The blacktop east of the diversion box } \\
\text { was contaminated up to } 3000 \text { counts per minute. The } \\
\text { dirt bank east of the posted radiation zone had } \\
\text { contaminated spots up to } 2000 \text { counts per minute and } \\
\text { weeds contaminated from } 300 \text { to } 800 \text { counts per } \\
\text { minute. Follow up surveys indicate the contamination } \\
\text { spread to be a result of a steam jet being left on at } 244- \\
\text { AR, resulting in the pressurization of the } 241-\text { AX-151 } \\
\text { Diverter Tank (WIDS). }\end{array}$ & $\begin{array}{l}\text { In } 1972, \text { the area was cleaned and the } \\
\text { cover blocks cracks were sealed } \\
\text { (WIDS). } \\
\text { A WIDS sign is located at the release } \\
\text { site }\end{array}$ \\
\hline UPR-200-E-47 & $\begin{array}{l}\text { Contaminated surfaces in the } \\
241-A \text { Tank Farm }\end{array}$ & $\begin{array}{l}\text { October 14, 1974: Contamination in the form of small } \\
\text { white specks was detected in the } 241 \text {-A Tank Farm on } \\
\text { October } 14,1974 \text {. The specks covered an area } \\
\text { approximately } 30 \text { meters ( } 100 \text { feet) by } 76 \text { meters ( } 250 \\
\text { feet), extending in a northwesterly direction from the } \\
702 \text {-A Vessel Ventilation Building. Contamination } \\
\text { levels ranged from } 30,000 \text { counts per minute near the } \\
\text { building to } 1,000 \text { counts per minute at the edge of the } \\
\text { spread. It was assumed the material had come from the }\end{array}$ & $\begin{array}{l}\text { In } 1974 \text {, the no. } 1 \text { filter in the } 702-\mathrm{A} \\
\text { building was replaced, the contaminated } \\
\text { soil was removed, and the area released } \\
\text { for normal service. }\end{array}$ \\
\hline
\end{tabular}


Table 4-5 241-A and 241-AX Unplanned Release Sites (Excludes suspected tank leaks)

\begin{tabular}{|c|c|c|c|}
\hline \multirow[t]{2}{*}{$\begin{array}{c}\text { UPR } \\
\text { Designation } \\
\end{array}$} & Location & Description & Status \\
\hline & & 702-A stack (IDMS Accession \# D195005336). & \\
\hline \multirow[t]{2}{*}{ 200-UPR-E-48 } & \multirow[t]{2}{*}{$\begin{array}{l}241-A-106 \text { pump pit and soil } \\
\text { nearby }\end{array}$} & $\begin{array}{l}\text { November 5, 1974: Failed jumpers and obsolete } \\
\text { equipment were being removed from the } 241-\mathrm{A}-106 \\
\text { pump pit on November } 5,1974 \text {. While a flex jumper } \\
\text { was being removed from the pit, the lower end caught } \\
\text { on an object, which momentarily raised and then } \\
\text { dropped back to the pit floor splashing contaminated } \\
\text { solution out of the pit to the soil nearby. An area } \\
\text { approximately } 10 \text {-ft by } 10 \text { - } \mathrm{ft} \text { was contaminated up to } \\
18 \text { rads per hour. The side of the instrument house was } \\
\text { also contaminated up to } 3 \text { rads per hour and part of one } \\
\text { cover block read off scale on a CP dose rate meter } \\
\text { (IDMS Accession \# D194052947). }\end{array}$ & $\begin{array}{l}\text { The contaminated soil was placed into } \\
\text { six, } 55 \text {-gallons drums and buried. The } \\
\text { contaminated soil was replaced with an } \\
\text { equal volume of clean dirt. Clean up of } \\
\text { the instrument house and cover block } \\
\text { was completed. }\end{array}$ \\
\hline & & $\begin{array}{l}\text { November 22, 1974: The } 241-\mathrm{A}-106 \text { cover blocks } \\
\text { were contaminated and had been wrapped in plastic to } \\
\text { prevent contamination spread. During the installation } \\
\text { of a new pump at the } 241-\mathrm{A}-106 \text { pump pit on } \\
\text { November } 22,1974 \text {, the cover blocks were unwrapped. } \\
\text { Wind caused contamination to spread from the exposed } \\
\text { cover blocks, affecting the } 241 \text {-A Tank Farm, several } \\
\text { personnel, five vehicles and the } 241-A \text { Tank Farm } \\
\text { parking area. Contamination levels ranged from } 700 \text { to } \\
2000 \text { counts per minute (IDMS Accession \# } \\
\text { D194052947). }\end{array}$ & $\begin{array}{l}\text { The parking areas and vehicles were } \\
\text { cleaned and returned to normal } \\
\text { operations on November } 22,1974 \text {. New } \\
\text { cover blocks fabricated and scheduled } \\
\text { for installation on November } 26,1975 \text {. }\end{array}$ \\
\hline UPR-200-E-115 & $\begin{array}{l}\text { 241-AX-103 Pump Pit and } \\
\text { soil nearby }\end{array}$ & $\begin{array}{l}\text { February 12, 1974: During bleeding of air from a line, } \\
\text { air flowed up (instead of down) causing contaminated } \\
\text { liquid to spray onto two employees and the ground } \\
\text { adjacent to the } 241-\mathrm{AX}-103 \text { Pump Pit. The employees } \\
\text { were wearing coveralls and assault masks. The } 241- \\
\text { AX- } 103 \text { pump pit was contaminated with levels up to } 5 \\
\text { rad per hour. The ground around the pump pit had } \\
\text { maximum contamination levels of } 2 \text { rad per hour } \\
\text { (WIDS). }\end{array}$ & Unknown \\
\hline
\end{tabular}


RPP-ENV-37956 Rev. 1

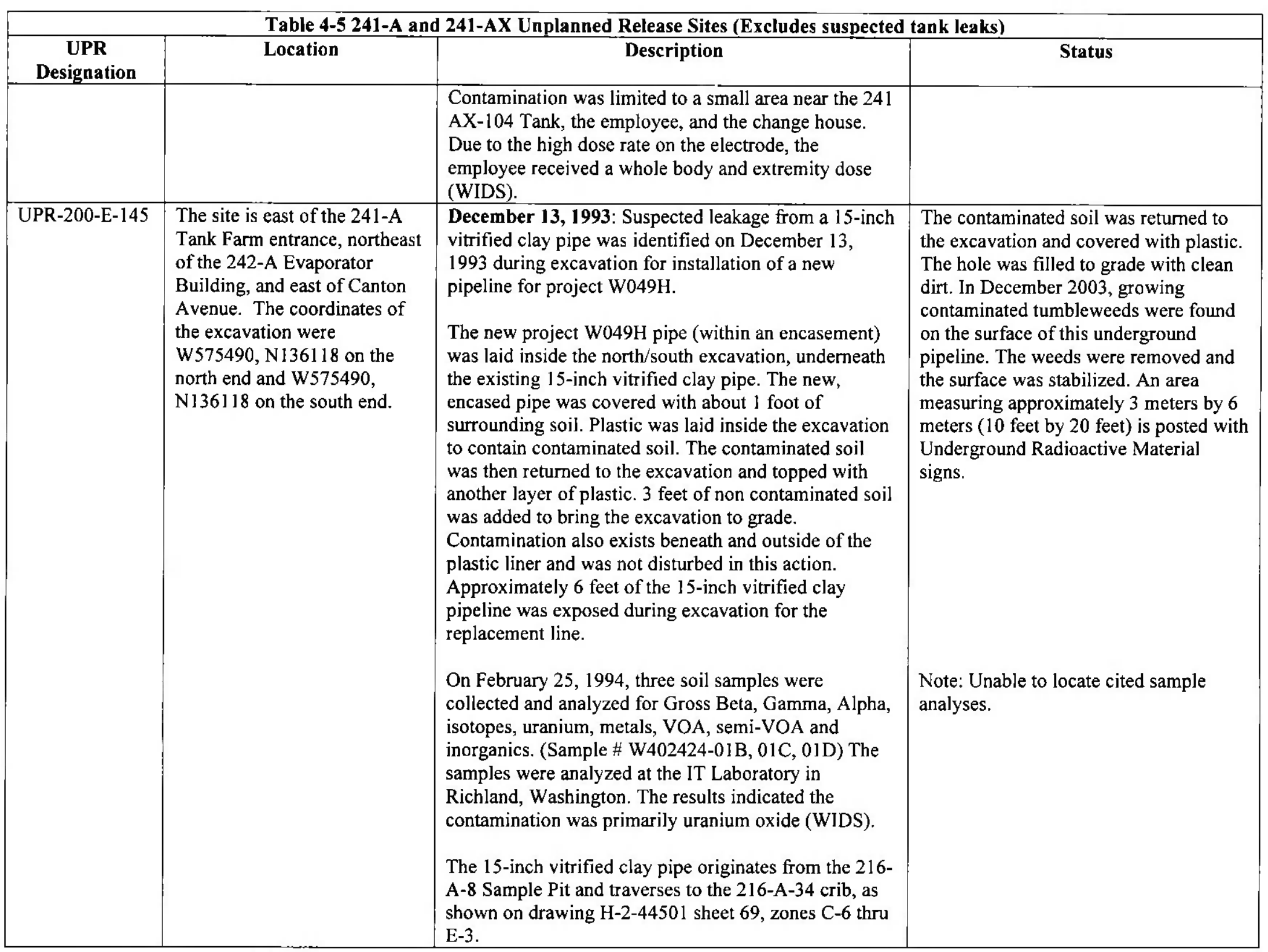




\begin{tabular}{|c|c|c|c|c|}
\hline \multicolumn{5}{|c|}{ Table 4-6 Potentially Failed Pipelines in 241-A and 241-AX Farms } \\
\hline Date & $\begin{array}{l}\text { Type of Event / } \\
\text { Facility }\end{array}$ & Event as Described in Reference & Reference & Comments \\
\hline $10-1957$ & $\begin{array}{l}\begin{array}{l}\text { Waste discharge to } \\
\text { ground }\end{array} \\
\text { Pipeline leak } \\
\text { 241-A Tank Farm } \\
\text { Offgas Ventilation } \\
\text { System Tank } 433\end{array}$ & $\begin{array}{l}\text { Page C-3: Considerable high level radiation work } \\
\text { was accomplished during the month at the } 241-\mathrm{A} \\
\text { Tank Farm. The work involved the inspection of a } \\
\text { portion of the } 412 \text { off-gas line, the replacement of } \\
\text { the } 433 \text { de-entrainment tank, and the subsequent } \\
\text { replacement of piping associated with the } 433 \text { tank. } \\
\text { Dose rates encountered during decontamination and } \\
\text { shielding varied from } 500 \text { to } 2,000 \text {-mrads/hr. The } \\
\text { maintenance work was accomplished at dose rates } \\
\text { varying from } 200 \text { to } 800 \text {-mrads/hr. The } \\
\text { replacement of the } 433 \text { tank piping was complicated } \\
\text { by contamination leaking from the failed lines. } \\
\text { This has necessitated repeated extensive } \\
\text { decontamination and shielding prior to continuing } \\
\text { maintenance work. The maximum radiation } \\
\text { measurement obtained from these leaks was } \\
\text { 12-rads/hr. } \\
\text { Page C-5: Replacement of the defective \#433 de- } \\
\text { entrainment tank in the underground waste storage } \\
\text { tank vent system was completed during the month. } \\
\text { Inasmuch as the defective carbon steel tank was } \\
\text { severely corroded a spare excess "T" Plant stainless } \\
\text { steel tank was modified and used as a replacement. } \\
\text { Page C-3: Replacement of failed piping on the de- } \\
\text { entrainment vessel (underground waste tank } \\
\text { condenser system) was performed with shielding at } \\
\text { a maximum personnel dose rate of } 1,500 \text {-mrads/hr. } \\
\text { In order to accomplish this work, it was necessary } \\
\text { to vent the boiling underground waste tanks to the } \\
\text { atmosphere via the inactive } 241-A-106 \text { tank. } \\
\text { Although a fiberglass filter placed over the vent } \\
\text { opening of } 106 \text { tank became contaminated to } 950- \\
\text { mrads/hr, contamination to the environs was } \\
\text { negligible. }\end{array}$ & $\begin{array}{l}\text { HW-53449 } \\
\text { HW- } 53967\end{array}$ & $\begin{array}{l}\text { The Tank } 433 \text { is located in the } 241-A-413 \text { Fan } \\
\text { House building nearby SST A-103. }\end{array}$ \\
\hline
\end{tabular}


RPP-ENV-37956 Rev. 1

\begin{tabular}{|c|c|c|c|c|}
\hline \multicolumn{5}{|c|}{ Table 4-6 Potentially Failed Pipelines in 241-A and 241-AX Farms } \\
\hline Date & $\begin{array}{c}\text { Type of Event / } \\
\text { Facility }\end{array}$ & Event as Described in Reference & Reference & Comments \\
\hline $11-1964$ & $\begin{array}{l}\text { 417-A jumper pit } \\
241-A \text { Tank Farm }\end{array}$ & $\begin{array}{l}\text { Several hundred gallons of condensed vapors from } \\
\text { the } 241 \text {-A waste storage tanks were pumped out of } \\
\text { a stub on the west side of the } 417-\mathrm{A} \text { jumper pit due } \\
\text { to installation of a jumper to the wrong nozzle by } \\
\text { construction forces. The condensate flow resulted } \\
\text { in a ground area being contaminated to } 50 \text { mrads at } \\
\text { surface. The construction forces backfilled the area } \\
\text { to cover this contamination. }\end{array}$ & RL-SEP-112 page B-3 & \\
\hline $1-28-1965$ & $\begin{array}{l}\text { 241-AX-151 diverter } \\
\text { station }\end{array}$ & 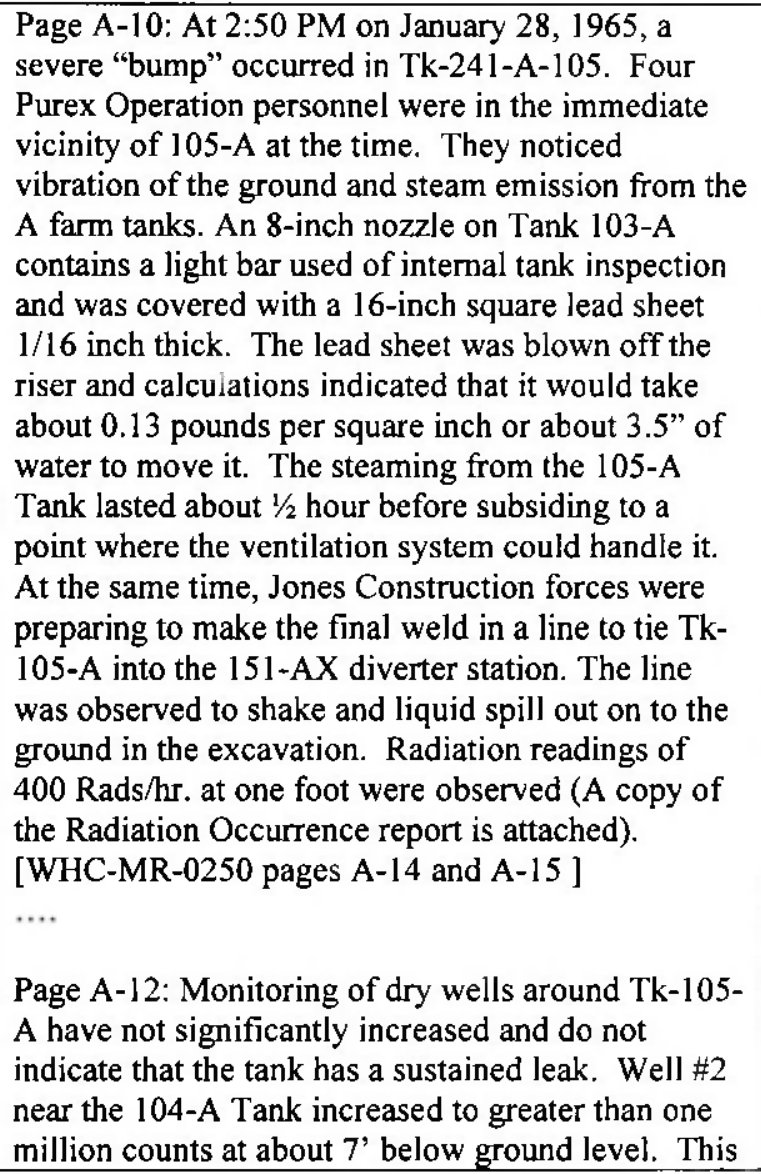 & WHC-MR-0250 & \\
\hline
\end{tabular}




\begin{tabular}{|c|c|c|c|c|}
\hline \multicolumn{5}{|c|}{ Table 4-6 Potentially Failed Pipelines in 241-A and 241-AX Farms } \\
\hline Date & $\begin{array}{c}\text { Type of Event / } \\
\text { Facility }\end{array}$ & Event as Described in Reference & Reference & Comments \\
\hline & & $\begin{array}{l}\text { increase was very likely due to the back-up of } \\
\text { activity into the new line which drained out into an } \\
\text { excavation near the well. }\end{array}$ & & \\
\hline $2-1965$ & $\begin{array}{l}\text { Pipeline leak } \\
\text { Encasement } \\
\text { Near diversion box } 241 \text { - } \\
\text { A-152 }\end{array}$ & $\begin{array}{l}\text { On February 18, } 1965 \text { the } 244-\mathrm{CR} \text { Vault was found } \\
\text { flooded up to approximately the level of the tank } \\
\text { tops. Immediate steps were taken to reduce the } \\
\text { liquid level by jetting the solution to the } 011 \text { Tank. } \\
\text { Partial cause of the flooding is attributed to a } \\
\text { failure in the coating waste line which enters the } \\
\text { 151-CR diversion box. Drainage from this } \\
\text { diversion box collects in the } 002-\mathrm{CR} \text { vault sump. } \\
\text { Water from a sampler flush line and drainage from } \\
\text { rain and snow contributed to the liquid level in the } \\
\text { vault. To date, the } 001,002 \text {, and } 003 \text { sumps have } \\
\text { been emptied, and the } 011 \text { sump is being emptied, } \\
\text { to the } 011 \text { Tank. This liquid is being pumped from } \\
\text { the } 011 \text { Tank to Tank } 103-A \text { in the } 241-A \text { Tank } \\
\text { Farm. } \\
\text { In trying to establish a coating waste routing from } \\
\text { the Purex Plant to the } 241-C \text { Tank Farm a leak was } \\
\text { also discovered in the underground line adjacent to } \\
\text { the 152-A Diversion Box. Because of the two } \\
\text { apparent leaks in this line it has been abandoned as } \\
\text { being unusable. }\end{array}$ & RL-SEP-332 page B-2 & $\begin{array}{l}\text { Failed line is } 8041 \text { per drawing H-2-2338, sheet } \\
45, \text { Diversion Box } 241-C R-152 \text { Nozzle } \\
\text { Information. Line V8107 replaced the failed line } \\
8041 \text { per drawing H-2-33087, LN } 8107 \text { (241- } \\
\text { CR-152 TO 102C) V843 \& V844 (241-CR-151 } \\
\text { TO I02C) V050 \& V051 (241-A-152 TO 104C). }\end{array}$ \\
\hline $6-1966$ & $\begin{array}{l}\text { Tank } 241-\mathrm{AX}-103 \\
\text { AX-801A building }\end{array}$ & $\begin{array}{l}\text { Page 99: Approximately } 20 \text { gallons of } 103-\mathbf{A X} \\
\text { contents were spread on the } 801 \text {-A Control } \\
\text { Building floor during replacement of a portion of } \\
\text { the piping to circulator } 10 \text {. Extensive } \\
\text { decontamination has been performed by flushing } \\
\text { the interior of the building with caustic-tartrate, } \\
\text { caustic-permanganate, tartaric acid, and water. The } \\
\text { flush solutions have been discharged to two new } \\
\text { cribs constructed adjacent to the north perimeter of } \\
\text { the AX Tank Farm. The radiation readings have } \\
\text { been reduced from }>500 \mathrm{R} / \mathrm{hr} \text { to localized spots of } \\
10-20 \mathrm{R} / \mathrm{hr} \text {. }\end{array}$ & ISO-75 RD & $\begin{array}{l}\text { These cribs are the 216-A-39 crib shown on } \\
\text { drawing H-2-33295, 216-A-39 Crib for Inst. } \\
\text { Enclosure } 241-\text { AX-801-B Plot Plan and Details. } \\
\text { The } 216-\mathrm{A}-39 \text { crib is identified as a WIDS site. } \\
\text { However, the waste discharged to the ground } \\
\text { around the } 801 \mathrm{~A} \text { building is not identified as a } \\
\text { UPR. } \\
\text { This event is also discussed in ISO-365 page I-2 } \\
\text { and ISO-428 page I-1. } \\
\text { ISO-416 states } 10 \text { to } 20 \text { gallons of tank } 241-\mathrm{AX}-\end{array}$ \\
\hline
\end{tabular}


RPP-ENV-37956 Rev. 1

Table 4-6 Potentially Failed Pipelines in 241-A and 241-AX Farms

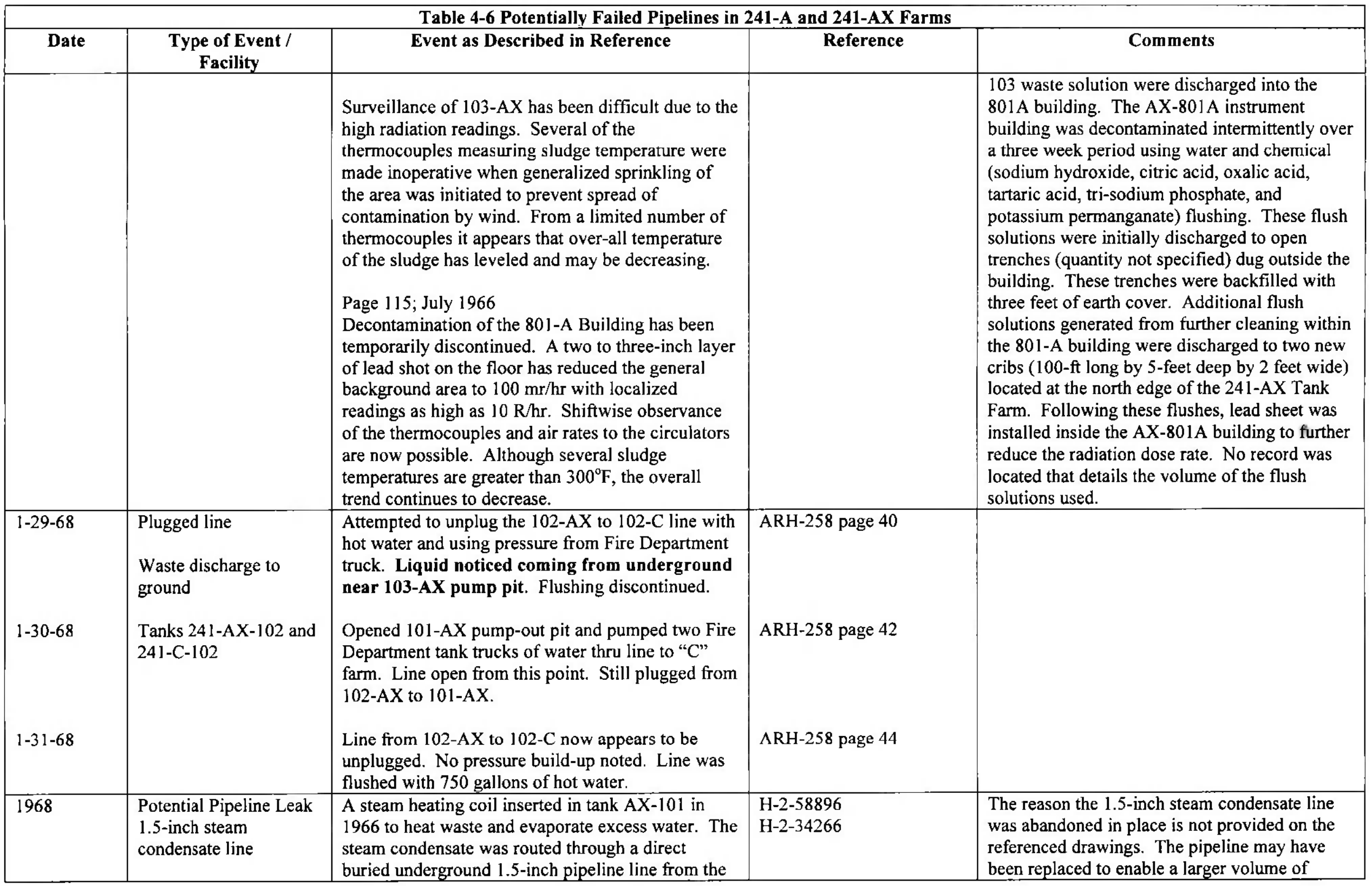


RPP-ENV-37956 Rev. 1

\begin{tabular}{|c|c|c|c|c|}
\hline \multicolumn{5}{|c|}{ Table 4-6 Potentially Failed Pipelines in 241-A and 241-AX Farms } \\
\hline Date & $\begin{array}{l}\text { Type of Event / } \\
\text { Facility }\end{array}$ & Event as Described in Reference & Reference & Comments \\
\hline & & $\begin{array}{l}\text { coil to condensate collection tank } 241-\mathrm{A}-417 \text {, as } \\
\text { shown on drawing H-2-58896. } \\
\text { In } 1968 \text {, the } 1.5 \text {-inch steam condensate line was } \\
\text { abandoned in place and replaced by a new } 4 \text {-inch } \\
\text { direct buried pipeline. This new } 4 \text {-inch pipeline } \\
\text { routed steam condensate from two coils in tanks } \\
241-\mathrm{AX}-101 \text { and one coil in tank } 241-\mathrm{AX}-102 \text { to } \\
\text { tank } 241-\mathrm{A}-417 \text {, as shown on drawing H-2-34266. }\end{array}$ & & $\begin{array}{l}\text { steam condensate to be discharged to tank } 241- \\
\text { A-417. }\end{array}$ \\
\hline $1-1975$ & $\begin{array}{l}\text { Pipeline Leak } \\
\text { Line V-113 to diversion } \\
\text { box } 241-C-151\end{array}$ & $\begin{array}{l}\text { Scheduled ion-exchange processing of Purex sludge } \\
\text { supernatant (PSS) for cesium recovery was not } \\
\text { conducted during January. Failure of the existing } \\
\text { transfer route from Tank 103-AX to Tank 105-C to } \\
\text { meet pressure test requirements prevented } \\
\text { resumption of cesium ion-exchange feed deliveries } \\
\text { to B Plant. }\end{array}$ & ARH-LD-201 B page 13 & $\begin{array}{l}\text { See also IDMS Accession \# } \mathrm{D} 194042901, \\
\text { TRANSFER ROUTES FOR FEED TO THE } \\
\text { EVAPORATORS page } 26, \text { which identifies the } \\
\text { failed pipeline as line } \mathrm{V}-113 \text { between the } 103- \\
\text { AX pump pit and the } 151-\mathrm{C} \text { diversion box. }\end{array}$ \\
\hline $1-1975$ & $\begin{array}{l}\text { Leakage of condensate } \\
\text { from } 241-A X \text { offgas } \\
\text { header Dresser } \\
\text { couplings }\end{array}$ & $\begin{array}{l}\text { The investigation determined that the exhaust vapor } \\
\text { header system to the AX tanks was the source of } \\
\text { several sizeable radiation leaks to the soil. Test } \\
\text { probing suggested that the Dresser couplings in the } \\
\text { vapor header system had suffered degradation with } \\
\text { a resulting loss of service integrity. }\end{array}$ & $\begin{array}{l}\text { IDMS Accession \# } \\
\text { D195006631 }\end{array}$ & $\begin{array}{l}\text { Dresser couplings were installed on the 241-A } \\
\text { and 241-AX vapor header system. Deterioration } \\
\text { and leak from the Dresser couplings could have } \\
\text { occurred throughout the operational life of these } \\
\text { tank farms (i.e. } 1956-1980 \text { ). }\end{array}$ \\
\hline $3-25-1980$ & $\begin{array}{l}\text { Pipeline Leak } \\
\text { F-100 condensate return } \\
\text { line }\end{array}$ & $\begin{array}{l}\text { On March } 25,1980 \text {, a routine pressure test of the F- } \\
100 \text { condensate return line (buried) from } 501-A X \\
\text { valve pit to the } 417 \text { condensate catch tank (i.e. TK- } \\
\text { A-417) failed. } \\
\text { Investigation on April } 3,1980 \text { revealed a leak at a } \\
\text { flange connection adjacent to the } 417 \text { Tank. }\end{array}$ & $\begin{array}{l}\text { IDMS Accession \# } \\
\text { D197182689 }\end{array}$ & $\begin{array}{l}\text { The line was excavated and } 1 \text { to } 2 \text { barrels of } \\
\text { contaminated soil }(10,000 \mathrm{c} / \mathrm{m}) \text { were removed to } \\
\text { the burial ground. The leak was determined to } \\
\text { be at a gasket on a flange on this pipeline. A } \\
\text { new gasket was installed and plans were made } \\
\text { to replace the flanged joint with a welded joint } \\
\text { to avoid future leaks. }\end{array}$ \\
\hline
\end{tabular}


RPP-ENV-37956 Rev. 1

\subsection{References}

ARH-78, 1967, PUREX TK-105-A Waste Storage Tank Liner Instability and Its Implications on Waste Containment and Control, Atlantic Richfield Hanford Company, Richland, Washington

ARH-258, 1968, Chemical Processing Division Daily Production Reports January 1968 through March 1968, Atlantic Richfield Hanford Company Richland Washington

ARH-326, 1968, Chemical Processing Department Waste Status Summary October 1, 1967 through December 31, 1967, Atlantic Richfield Hanford Company, Richland Washington

ARH-534, 1968, Chemical Processing Department Waste Status Summary January 1, 1968 through March 31, 1968, Atlantic Richfield Hanford Company, Richland Washington

ARH-721, 1968, Chemical Processing Department Waste Status Summary April 1, 1968 through June 30, 1968, Atlantic Richfield Hanford Company, Richland Washington

ARH-871, 1968, Chemical Processing Department Waste Status Summary July 1, 1968 through September 30, 1968, Atlantic Richfield Hanford Company, Richland Washington

ARH-1023-3-DEL, 1969, Chemical Processing Division Daily Production Reports July, 1969 through September, 1969, Atlantic Richfield Hanford Company, Richland, Washington

ARH-1061, 1969, Chemical Processing Department Waste Status Summary October 1, 1968 through December 31, 1968, Atlantic Richfield Hanford Company, Richland Washington

ARH-1200 A, 1969, Chemical Processing Division Waste Status Summary January 1, 1969 through March 31, 1969, Atlantic Richfield Hanford Company, Richland Washington

ARH-1200 B, 1969, Chemical Processing Division Waste Status Summary April 1, 1969 through June 30, 1969, Atlantic Richfield Hanford Company, Richland Washington

ARH-1200 C, 1969, Chemical Processing Division Waste Status Summary July 1, 1969 through September 30, 1969, Atlantic Richfield Hanford Company, Richland Washington

ARH-1200 D, 1970, Chemical Processing Division-Waste Status Summary October 1, 1969 through December 31, 1969, Atlantic Richfield Hanford Company, Richland Washington

ARH-1666 A, 1970, Chemical Processing Division Waste Status Summary January 1, 1970 through March 31, 1970, Atlantic Richfield Hanford Company, Richland Washington

ARH-1666 B, 1970, Chemical Processing Division Waste Status Summary April 1, 1970 through June 30, 1970, Atlantic Richfield Hanford Company, Richland Washington

ARH-1666 C, 1970, Chemical Processing Division Waste Status Summary July 1, 1970 through 
September 30, 1970, Atlantic Richfield Hanford Company, Richland Washington

ARH-1666 D, 1971, Chemical Processing Division-Waste Status Summary October 1, 1970 through December 31, 1970, Atlantic Richfield Hanford Company, Richland Washington

ARH-2074 A, 1971, Chemical Processing Division Waste Status Summary January 1, 1971 through March 31, 1971, Atlantic Richfield Hanford Company, Richland Washington

ARH-2074 B, 1971, Chemical Processing Division Waste Status Summary April 1, 1971 through June 30, 1971, Atlantic Richfield Hanford Company, Richland Washington

ARH-2456 A, 1972 Chemical Processing Division Waste Status Summary, January 1, 1972 through March 31, 1972, Rockwell Hanford Operations, Richland, Washington

ARH-2456 B, 1972, Chemical Processing Division Waste Status Summary April 1, 1972 through June 30, 1972, Atlantic Richfield Hanford Company, Richland Washington

ARH-2456 C, 1972, Chemical Processing Department Waste Status Summary July 1, 1972 through September 30, 1972, Atlantic Richfield Hanford Company, Richland Washington

ARH-2456 D, 1973, Chemical Processing Department Waste Status Summary October 1, 1972 through December 31, 1972, Atlantic Richfield Hanford Company, Richland Washington

ARH-2794 A, 1973 Chemical Processing Division Waste Status Summary, January 1, 1973 through March 31, 1973, Rockwell Hanford Operations, Richland Washington

ARH-2794 B, 1973 Chemical Processing Division Waste Status Summary, April 1, 1973 through June 30, 1973, Atlantic Richfield Hanford Company, Richland Washington

ARH-2794 D, 1974, Chemical Processing Department Waste Status Summary October 1, 1973 through December 31, 1973, Atlantic Richfield Hanford Company, Richland Washington

ARH-CD-133 A, 1974 Chemical Processing Division Waste Status Summary, January 1, 1974 through March 31, 1974, Rockwell Hanford Operations, Richland Washington

ARH-CD-133 C, 1974, Production and Waste Management Division Waste Status Summary July 1, 1974 through September 30, 1974, Atlantic Richfield Hanford Company, Richland Washington

ARH-CD-336 B, 1975, Production and Waste Management Division Waste Status Summary April 1, 1975 through June 30, 1975, Atlantic Richfield Hanford Company, Richland Washington

ARH-CD-587, 1976, Containment of the Deteriorated Vapor Exhaust Header in 241-AX Tank Farm, Atlantic Richfield Hanford Company, Richland Washington 
ARH-CD-702 A, 1976 Chemical Processing Division Waste Status Summary, January 1, 1976 through March 31, 1976, Atlantic Richfield Hanford Company, Richland Washington

ARH-LD-120, 1975, Nuclear Waste Tank and Pipeline External Leak Detection Systems, Atlantic Richfield Hanford Company, Richland Washington

ARH-CD-133 A, 1974, Operations Division Waste Status Summary January 1, 1974 through March 31, 1974, Atlantic Richfield Hanford Company, Richland, Washington

ARH-CD-133 B, 1974, Operations Division Waste Status Summary April 1, 1974 through June 30, 1974, Atlantic Richfield Hanford Company, Richland, Washington

ARH-CD-133 C, 1974, Production and Waste Management Division Waste Status Summary July 1, 1974 through, September 30, 1974, Atlantic Richfield Hanford Company, Richland, Washington

ARH-CD-133 D, 1975, Production and Waste Management Division Waste Status Summary October 1, 1974 through December 31, 1974, Atlantic Richfield Hanford Company, Richland, Washington

ARH-CD-702 A, 1976, Production and Waste Management Division Waste Status Summary January 1, 1976 through March 31, 1976, Atlantic Richfield Hanford Company, Richland, Washington

ARH-CD-702 B, 1976, Production and Waste Management Division Waste Status Summary April 1, 1976 through June 30, 1976, Atlantic Richfield Hanford Company, Richland, Washington

ARH-LD-201 B, 1975, Atlantic Richfield Hanford Company Monthly Report January 1975, Atlantic Richfield Hanford Company, Richland Washington

ARH-LD-206 B, 1975, Atlantic Richfield Hanford Company Monthly Report June 1975, Atlantic Richfield Hanford Company, Richland, Washington

ARH-LD-207 B, 1975, Atlantic Richfield Hanford Company Monthly Report July 1975, Atlantic Richfield Hanford Company, Richland, Washington

ARH-LD-209 B, 1975, Atlantic Richfield Hanford Company Monthly Report September 1975, Atlantic Richfield Hanford Company, Richland Washington

ARH-LD-212 B, 1976, Atlantic Richfield Hanford Company Monthly Report December 1975, Atlantic Richfield Hanford Company, Richland Washington

ARH-LD-214 B, 1976, Atlantic Richfield Hanford Company Monthly Report February 1976, Atlantic Richfield Hanford Company, Richland Washington 
ARH-LD-215 B, 1976, Atlantic Richfield Hanford Company Monthly Report March 1976, Atlantic Richfield Hanford Company, Richland Washington

ARH-LD-216 B, 1976, Atlantic Richfield Hanford Company Monthly Report April 1976, Atlantic Richfield Hanford Company, Richland Washington

ARH-LD-222 B, 1976, Atlantic Richfield Hanford Company Monthly Report October 1976, Atlantic Richfield Hanford Company, Richland Washington

ARH-LD-223 B, 1976, Atlantic Richfield Hanford Company Monthly Report November 1976, Atlantic Richfield Hanford Company, Richland Washington

ARH-LD-224 B, 1977, Atlantic Richfield Hanford Company Monthly Report December 1976, Atlantic Richfield Hanford Company, Richland Washington

ARH-LD-227 B, 1977, Atlantic Richfield Hanford Company Monthly Report March 1977, Atlantic Richfield Hanford Company, Richland Washington

ARH-LD-229 B, 1977, Atlantic Richfield Hanford Company Monthly Report May 1977, Atlantic Richfield Hanford Company, Richland Washington

Baumhardt, 1989, "Unusual Occurrence Report WHC-UO-88-043-TF-07, TK 241-A-103", Don't Say It --- Write It dated January 5, 1989 from R. J. Baumhardt to J. G. Burk, Westinghouse Hanford Company, Richland Washington

Baumhardt 1989, Single-Shell Tank Leak Volumes, letter number 8901832B R1 dated May 17, 1989 from R. J. Baumhardt, Westinghouse Hanford Company to R. E. Gerton, U. S. Department of Energy Richland Washington

Burton, G., 1975, Status of Tank 241-A-104 Contract E(45-1)-2130, letter dated July 10, 1975 from G. Burton Vice President Production and Waste Management Atlantic Richfield Hanford Company to O. J. Elbert, Director Production and Waste Management Programs Division, U.S. Energy Research and Development Administration, Richland Washington

DOE/RL-88-30, rev. 16, 2007, Hanford Site Waste Management Units Report, Fluor, Richland Washington

DOE/ORP-2005-01, 2006, Initial Single-Shell Tank System Performance Assessment for the Hanford Site, U.S. Department of Energy Office of River Protection, Richland Washington

RPP-35484, Field Investigation Report for Waste Management Areas $C$ and A-AX, M. P. Connelly, CH2M HILL Hanford Group Inc., Richland Washington 
EPDR 87-02, March 12, 1987, Environmental Protection Deviation Report 87-02, Tank 103-A Surface Level Measurement (FIC) Exceeding the Two-Inch Decrease Criteria, Westinghouse Hanford Company, Richland Washington

GJO-97-14-TAR, GJO-HAN-12, 1997, Vadose Zone Characterization Project at the Hanford Tank Farms: AX Tank Farm Report, U.S. Department of Energy, Grand Junction Office, Grand Junction, Colorado

H-2-2257, 1951, Conductor Reel for Liquid Level Measurement, General Electric Company, Richland Washington

H-2-2338, sheet 45, revision 5, 1976, Diversion Box 241-CR-152 Nozzle Information, Atlantic Richfield Hanford Company, Richland Washington

H-2-33087, revision 7, 1972, LN 8107 (241-CR-152 TO 102C) V843 \& V844 (241-CR-151 TO 102C) V050 \& V051 (241-A-152 TO 104C), U. S. Atomic Energy Commission Richland Operations Office, Richland Washington

H-2-33295, revision 3, 1973, 216-A-39 Crib for Inst. Enclosure 241-AX-801-B Plot Plan and Details, U. S. Atomic Energy Commission Richland Operations Office, Richland Washington

H-2-34266, rev. 4, 1969, 4" Steam Condensate Line 241-AX-101 to 241-A-417 Plan \& Det's, Atlantic Richfield Hanford Company, Richland Washington

H-2-35091, revision 1, 1969, TK-104-A Heater, Atlantic Richfield Hanford Company, Richland Washington

H-2-44501, sheet 69, revision 12, 1978, Area Map-200 East A Plant Facilities, Rockwell Hanford Operations, Richland Washington.

H-2-58896, revision 4, 1969, Plan \& Profile Steam Condensate Line TK-101 to TK-A-417, U.S. Atomic Energy Commission Richland Operations Office, Richland Washington

HAN-90650, 1965, Monthly Status and Progress Report January 1965, U.S. Atomic Energy Commission Richland Operations Office, Richland Washington

HNF-EP-0182, rev. 238, 2008, Waste Status Summary Report for Month Ending January 31, 2008, CH2M HILL Hanford Group Inc., Richland WA

HNF-SD-WM-TI-740, revision 0C, 1999, Standard Inventories of Chemicals and Radionuclides in Hanford Tank Wastes, Lockheed Martin Hanford Corporation, Richland Washington

HNF-SD-RE-Tl-178, rev. 9, 2005, Single-Shell Tank Interim Stabilization Record, CH2M HILL Hanford Group Inc., Richland Washington 
HNF-SD-WM-ER-472, rev. 2, 1999, Tank Characterization Report for Single-Shell Tank 241$A X-102$, Lockheed Martin Hanford Corporation, Richland Washington

HW-10475-C, 1944, Hanford Technical Manual Section C, I. E. Du Pont De Nemours, Richland, Washington

HW-43490, 1956, Separations Section Waste Status Summary for May 1956, General Electric Company, Richland Washington

HW-43895, 1956, Separations Section Waste Status Summary for June 1956, General Electric Company, Richland Washington

HW-44506, 1956, Design Bases and Performance Characteristics of the PUREX 241-A Waste Tank Farm Condensate Disposal Facility, General Electric Company, Richland Washington

HW-44580, 1956, Monthly Report Hanford Atomic Production Operation for July 1956, General Electric Company, Richland Washington

HW-44860, 1956, Separations Section Waste Status Summary for July 1956, General Electric Company, Richland Washington

HW-45707, 1956, Chemical Processing Department Monthly Report for September 1956, General Electric Company, Richland Washington

HW-51026, 1957, Leak Detection - Underground Storage Tanks, General Electric Company, Richland WA

HW-51348, 1957, Waste- Status Summary; Chemical Processing Department, Planning and Scheduling - Production Operation June 1, 1957 - June 30, 1957, General Electric Company, Richland, Washington

HW-51399, 1957, Calculation of PUREX A-8 Crib Capacity, General Electric Hanford Atomic Products Operation, Richland Washington

HW-53449, 1957, Chemical Processing Department Monthly Report for October 1957, General Electric Company, Richland Washington

HW-53967, 1957, Chemical Processing Department Monthly Report for November 1957, General Electric Company, Richland Washington

HW-57550, 1958, Waste-Status Summary; Chemical Processing Department, August 31, 1958, Hanford Atomic Products Operation, Richland, Washington 
HW-63949, 1959, Quarterly Progress Report Research and Development Activities Fixation of Radioactive Residues October - December 1959, General Electric Hanford Atomic Products Operation, Richland Washington

HW-60807, 1959, Unconfined Underground Radioactive Waste and Contamination in the 200 Areas - 1959, General Electric Company, Richland Washington.

HW-61952, 1959, Waste- Status Summary; Chemical Processing Department, September 17, 1959, Hanford Atomic Products Operation, Richland, Washington

HW-66276, 1960, The Removal of Cesium and Strontium from Condensate Wastes with Clinoptilolite, General Electric Hanford Atomic Products Operation, Richland Washington

HW-66557, 1960, Chemical Processing Department Waste-Status Summary July 1, 1960 - July 31, 1960, Hanford Atomic Products Operation, Richland, Washington

HW-79174, 1963, Progress in Treatment of a Radioactive Condensate Waste, General Electric Hanford Atomic Products Operation, Richland Washington

HW-80877, 1964, Radioactive Contamination in Liquid Wastes Discharged to Ground at the Separations Facilities Through 1963, General Electric Company, Richland Washington

HW-81620, 1964, Chemical Processing Department Monthly Report for March 1964, General Electric Company, Richland Washington

IDMS Accession \#292-000583, 1977, An Estimate of Bottom Topography Volume and Other Conditions In Tank 105A Hanford Washington, Woodward-Clyde Consultants, San Francisco California

IDMS Accession \#292-001152, 1988, Stabilization of Tank 241-AX-102, letter number 8855733 dated September 16, 1988 from R. D. Wojtasek, Westinghouse Hanford Company to R. E. Gerton, U.S. Department of Energy, Richland Washington

IDMS Accession \#292-001 156, 1988, Tank 102-AX, letter number 8855485 dated September 6, 1988 from R. D. Wojtasek, Westinghouse Hanford Company to R. E. Gerton, U.S. Department of Energy, Richland Washington

IDMS Accession \#292-001159, 1988, Waste Tank Integrity Evaluation Peer Review - Tank 241 $A X$-102, internal memo 13310-88-DEM-046 dated August 17, 1988 from D. E. McKinney to D. J. Washenfelder, Westinghouse Hanford Company, Richland Washington

IDMS Accession \#293-002393, 1988, Fact Sheet Number TFS\&O-EFS-88-092 Surface Level Measurement Decrease in Single-Shell Tank 241-AX-102, dated July 26, 1988, Westinghouse Hanford Company, Richland Washington 
IDMS Accession \#293-003399, 1977, Approval of Tank 102-AX for Salt Cake Storage, letter dated August 25, 1977 from J. W. Bailey to D. C. Bartholomew, Rockwell International, Richland Washington

IDMS Accession \#293-006415, 1977, Occurrence Report \#77-202 Radiation Peak in Dry Well 11-04-08 Exceeding Increase Criterion, Rockwell Hanford Operations, Richland Washington

IDMS Accession \#D193015327, 1978, Additional Information for Tank 104-AX, internal letter dated July 12, 1978 from D. W. Everly to G. D. Campbell, Rockwell International, Richland Washington

IDMS Accession \#D194030828, 1984, TK-102-AX Liquid Level Decrease, internal letter 6595084-132 dated February 29, 1984 from C. M. Walker to J. F. Dickman, Rockwell International, Richland Washington

IDMS Accession \#D194031937, 1983, Pumping of Supernatant from Tank 102-AX, internal letter 65950-83-1650 dated November 23, 1983 from N. E. Bell to R. A. Zinsli, Rockwell International, Richland Washington

IDMS Accession \#D194032070, 1978, Removal of Single-Shell Tank 104-AX from Active Service Contract EY-77-C-06-1030, letter dated August 28, 1978 from J. H. Roecker, Rockwell International to O. J. Elgert, U.S. Department of Energy, Richland Washington

IDMS Accession \#D194035016, 1980, Occurrence Report \#78-47 Radioactive Discharge Exceeding Specified Limits, Rockwell International, Richland Washington

IDMS Accession \#D194035034, 1978, Occurrence Report \#78-15 Tank 103-A Liquid Level Decrease Exceeding Criterion, Rockwell International, Richland Washington

IDMS Accession \#D194044995, 1977, Radiation in AX Leak Detection Pits, letter dated May 25, 1977 from N. P. Willis to J. L. Deichman, Atlantic Richfield Hanford Company, Richland Washington

IDMS Accession \#D194052912, 1977, Occurrence Report \#77-202, Radiation Peak in Dry Well 11-04-08 Exceeding Increase Criterion, Rockwell Hanford Operations, Richland Washington

IDMS Accession \# D194052947, 1974, Occurrence Report \#74-144 ARHCO Occurrence Report 106-A Pump Pit dated November 5, 1974, Atlantic Richfield Hanford Company Operations, Richland Washington

IDMS Accession \# D194052992, 1975, Occurrence Report \#75-47, Increasing Dry Well Radiation Adjacent to Tank 104-AX, Atlantic Richfield Hanford Company, Richland Washington 
IDMS Accession \#D194050777, 1975, 241-AX-102 Leak Detection, letter dated June 4, 1975 from H. F. Jensen to R. M. Smithers, Atlantic Richfield Hanford Company, Richland Washington

IDMS Accession \#D194052941, Occurrence Report 74-130, Contamination Spread 241-A Tank Farm, dated September 20, 1974, Atlantic Richfield Hanford Company, Richland Washington

IDMS Accession \# D194052947, 1974, Occurrence Report \#74-150 ARHCO Occurrence Report 241-A-106 Pump Pit dated November 22, 1974, () Atlantic Richfield Hanford Company Operations, Richland Washington

IDMS Accession \#D19405298, Occurrence Report 75-39, Leakage from Tank 104-A, dated April 8, 1975, Atlantic Richfield Hanford Company, Richland Washington

IDMS Accession \#D194052856, 1977, Occurrence Report \#77-141 Tank 103-A Liquid Level Exceeding Decrease Criterion, Rockwell Hanford Operations, Richland Washington

IDMS Accession \#D194053459, 1979, Occurrence Report \#79-118 Tank 103-A Liquid Level Decrease, Rockwell Hanford Operations, Richland Washington

IDMS Accession \# D195005336, 1974, Occurrence Report \#74-135 ARHCO Occurrence Report Spread of Contamination dated October 14-15, 1974, Atlantic Richfield Hanford Company Operations, Richland Washington

IDMS Accession \#D195005364, 1975, Occurrence Report 75-60, Increasing Radiation in a Dry Well Adjacent to Tank 102-AX, Atlantic Richfield Hanford Company, Richland Washington

IDMS Accession \#D195006631, 1976, Addendum, Atlantic Richfield Hanford Company Occurrence Report 75-90, "Increase Dry Well Radiation Adjacent to Tank 102-AX" Contract E(45-l)-2130, letter from G. Burton, Atlantic Richfield Hanford Company to O. J. Elbert, U.S. Energy Research and Development Administration, Richland Washington

IDMS Accession \# D196165963, Internal Letter 65950-87-249, 1987, Surface Level Behavior of Tank 241-A-103, dated April 21, 1987 from D. R. Groth to B. F. Weaver, Rockwell International, Richland Washington

IDMS Accession \#D196215974, 1980, Occurrence Report No. 80-82 Tank 103-A Liquid Level Decrease - Final Report, Rockwell Hanford Operations, Richland Washington

IDMS Accession \#D196248072, Analysis of Tank Farm Samples Sample: T-2893 Tank 104-A, dated March 4, 1974, Atlantic Richfield Hanford Company, Richland Washington 
IDMS Accession \#D197137077, 1975, Tank Farm Soil Conductivity and Radiation Survey, letter dated June 6, 1975 from K. T. Key and L. E. Bruns, Atlantic Richfield Hanford Company, Richland Washington

IDMS Accession \# D197182689, 1980, Occurrence Report No. 80-41 Unexpected Leakage of F-100 Condensate Return, Rockwell Hanford Operations, Richland Washington

IDMS Accession \#D197183104, 1980, Occurrence Report No. 80-82 Tank 103-A Liquid Level Decrease - Interim Report, Rockwell Hanford Operations, Richland Washington

IDMS Accession \#D197260431, History - 24l-A Tank Farm, memo dated May 21, 1963 D. L. Uebelackler, General Electric Company, Richland Washington

IDMS Accession \# D199126708, Internal Letter 65950-87-326, 1987, Tank 103-A Integrity Evaluation, dated May 15, 1987 from D. R. Groth and G. C. Owens to J. H. Roecker, Rockwell International, Richland Washington

Internal Letter 65000-WWS-87-033, 1987, Tank 103-A Integrity Evaluation, dated May 5, 1987 from W. W. Schulz to J. H. Roecker, Rockwell International, Richland Washington

Internal Letter 65950-87-291, 1987, Tank 241-A-103, dated May 5, 1987 from D. W. Lindsey to W. W. Schulz, Rockwell International, Richland Washington

Interoffice Memo 7G420-06-004, 2006, Estimation of Tank 24l-A-105 Supernatant Cesium-137 Concentration During Sluicing in August 1968, M. E. Johnson, CH2M HILL Hanford Group, Inc., Richland, Washington

Interoffice Memo 7G420-06-005, 2006, Estimation of Tank 241-A-105 Supernatant Cesium-137 Concentration During Second Sluicing Campaign Conducted July 1969 Through November 1970, M. E. Johnson, CH2M HILL Hanford Group, Inc., Richland, Washington

ISO-75 RD, 1966, Fission Products Process Engineering Monthly Report .January thru December 1966, ISOCHEM Inc., Richland Washington

ISO-365, 1966, Chemical Processing Department Monthly Report for June 1966, ISOCHEM Inc., Richland Washington

ISO-404, 1966, Chemical Processing Department Waste Status Summary April 1, 1966 through June 30, 1966, ISOCHEM Inc., Richland Washington

ISO-416, 1966, Report of Investigation Radiation Occurrence and Contamination Spread 801-A Bldg., 200-E Area, ISOCHEM Inc., Richland Washington 
ISO-428-DEL, 1966, Chemical Processing Department Monthly Report for July 1966, ISOCHEM Inc., Richland Washington

ISO-538, 1966, Chemical Processing Department Waste Status Summary July 1, 1966 through September 30, 1966, ISOCHEM Inc., Richland Washington

ISO-651 RD, 1966, Fission Products Process Engineering Monthly Report January thru December 1967, ISOCHEM Inc., Richland Washington

ISO-674, 1967, Chemical Processing Department Waste Status Summary October 1, 1966 through December 31, 1966, ISOCHEM Inc., Richland Washington

ISO-806, 1967, Chemical Processing Department Waste Status Summary January 1, 1967 through March 31, 1967, ISOCHEM Inc., Richland Washington

Jansen et al. 1965. G. Jansen, Jr., W.E. Willingham, and W.V. DeMier, 1965, Techniques for Calculating Tank Temperatures and Soil Temperatures Near Leaks - Application to Purex Waste Tank 105A, Battelle Northwest, Richland Washington

Mercer, 1969, Ion Exchange Treatment of 241-A and 241-AX Tank Farm Condensates, letter dated April 24, 1969 from B. W. Mercer to G. L. Hanson, Battelle Northwest Pacific Northwest Laboratory, Richland Washington

OR-76-08, 1976, Occurrence Report 76-08 Radiation Increase Monitored by Tank Dry Well, Atlantic Richfield Hanford Company, Richland Washington

OR-76-59, 1976, Occurrence Report 76-59, Monitoring Dry Well Has Shown Increase in Radiation Exceeding Action Criteria, Atlantic Richfield Hanford Company, Richland Washington

OR-77-36, 1977, Occurrence Report 77-36, Liquid Level Decrease Exceeding Criteria for Tank 101-AX, Atlantic Richfield Hanford Company, Richland Washington

PNL-4688, 1983, Assessment of Single-Shell Tank Residual Liquid Issues, Murthy, K. S., et al., Pacific Northwest Laboratory, Richland, Washington

PPD-493-9-DEL, 1972, Monthly Status \& Progress Report September 1972, Atomic Energy Commission Richland Washington

PR-REPORT-JAN70, rev. 1, 1970, Monthly Status \& Progress Report January 1970, U.S. Atomic Energy Commission Richland Operations Office, Richland Washington

PR-REPORT FEB70, rev. 1, 1970, Monthly Status \& Progress Report February 1970, Atomic Energy Commission Richland Washington 
PR-REPORT MAR70, rev. 1, 1970, Monthly Status \& Progress Report March 1970, Atomic Energy Commission Richland Washington

PR-REPORT APR70, rev. 1, 1970, Monthly Status \& Progress Report April 1970, Atomic Energy Commission Richland Washington

PR-REPORT MAY70, rev. 1, 1970, Monthly Status \& Progress Report May 1970, Atomic Energy Commission Richland Washington

PR-REPORT JUN70, rev. 1, 1970, Monthly Status \& Progress Report June 1970, Atomic Energy Commission Richland Washington

RHO-CD-14 May 1980, 1980, Waste Status Summary May 1980, Rockwell Hanford Operations, Richland Washington

RHO-CD-80-1045 5, 1980, Reconcentration of Second PN Campaign Wastes, 242-A Evaporator-Crystallizer Campaign 80-5 March 12 to April 4, 1980, Rockwell Hanford Operations, Richland Washington

RHO-CD-80-1045 6, 1980, Dilute Complexed Waste Concentration 242-A EvaporatorCrystallizer Campaign 80-6 April 10 to April 27, 1980, Rockwell Hanford Operations, Richland Washington

RHO-CD-673, 1979, Handbook 200 Areas Waste Sites, Rockwell Hanford Operations, Richland Washington

RHO-CD-1 172, 1981, Survey of the Single-Shell Tank Thermal Histories, Rockwell Hanford Operations, Richland Washington

RHO-CD-1193, 1981, Review of Classification of Hanford Single-Shell Tanks 110-B, 111-C, 103-T, 107-TX, 104-TY, and 106-U, Rockwell Hanford Operations, Richland Washington

RHO-R-39, 1969, Boiling Waste Tank Farm Operational History, Rockwell Hanford Operations, Richland Washington

RHO-RE-SR-14 - May 1982, Waste Status Summary May 1982, Rockwell Hanford Operations, Richland Washington

RHO-RE-SR-14 - September 1983, Waste Status Summary September 1983, Rockwell Hanford Operations, Richland Washington

RL-SEP-9, 1964, PUREX 241-AX Tank Farm and Waste Routing System Information Manual, General Electric Company, Richland Washington

RL-SEP-112-DEL, 1964, Chemical Processing Department Monthly Report for November 1964, General Electric Company, Richland Washington 
RL-SEP-183-RD, 1964, PUREX Tank Farm Supernatant Solution Composition, IDMS Accession \# D197217929, General Electric Hanford Atomic Products Operation, Richland Washington

RL-SEP-332, 1965, Chemical Processing Department Monthly Report for February 1965, General Electric Company, Richland Washington

RL-SEP-821, 1965, Chemical Processing Department Waste Status Summary July 1, 1965 through September 30, 1965, General Electric Company, Richland Washington

RL-SEP-923, 1966, Chemical Processing Department Waste Status Summary October 1, 1965 through December 31, 1965, General Electric Company, Richland Washington

RPP-7494, 2001, Historical Vadose Zone Contamination from A, AX, and C Tank Farm Operations, Fluor Federal Services, Richland Washington

RPP-8821, rev. 0, Analysis and Summary Report of Historical Dry Well Gamma Logs for 241AX TANK FARM - 200 East, Three Rivers Scientific, West Richland Washington

RPP-10006, revision 7, 2007, Methodology and Calculations for the Assignment of Waste Groups for the Large Underground Waste Storage Tanks at the Hanford Site, CH2M HILL Hanford Group Inc., Richland Washington

RPP-10435, 2002, Single-Shell Tank System Integrity Assessment Report, CH2M HILL Hanford Group Inc., Richland Washington

RPP-23405, 2006, revision 2, Tank Farm Vadose Zone Contamination Estimates, CH2M HILL Hanford Group Inc., Richland Washington

RPP-25113, 2005, Residual Waste Inventories in Plugged and Abandoned Pipelines at the Hanford Site, CH2M HILL Hanford Group Inc., Richland Washington

RPP-26744, 2005, Hanford Soil Inventory Model Rev. 1, CH2M HILL Hanford Group Inc., Richland Washington

RPP-32681, 2007, Process to Estimate Tank Farm Vadose Zone Inventories, CH2M HILL Hanford Group Inc., Richland Washington

RPP-ENV-33418, revision 1, 2008, Hanford C-Farm Leak Assessments Report: 241-C-101, 241 C-110, 241-C-111, 241-C-105 and Unplanned Waste Releases, CH2M HILL Hanford Group Inc., Richland Washington

RPP-RPT-27605, 2006, Gamma Surveys of Single-Shell Tank Laterals in A and SX Tank Farms, CH2M HILL Hanford Group Inc., Richland WA 
RPP-RPT-29191, 2006, Supplemental Information Hanford Tank Waste Leaks, CH2M HILL Hanford Group Inc., Richland WA

SD-WM-TI-198, 1988, Data Transmittal Package for 241-A-103 Waste Tank Characterization, Westinghouse Hanford Company, Richland Washington

SD-WM-TI-302, 1987, Hanford Waste Tank Sluicing History, Westinghouse Hanford Company, Richland Washington

SD-WM-TI-356, 1988, Waste Storage Tank Status and Leak Detection Criteria, Westinghouse Hanford Company, Richland Washington

TFC-ENG-CHEM-D-42, Tank Leak Assessment Process, CH2M HILL Hanford Group Inc., Richland Washington

TFSA\&S-89-48, 1989, Tank 24I-AX-102 Surface Level Measurement Decrease, Westinghouse Hanford Company, Richland Washington

Vermeulen, 1987, “103-A FIC Reading”, Don't Say It --- Write It dated November 19, 1987 from N. J. Vermeulen to R. K. Welty, Westinghouse Hanford Company, Richland Washington

WHC-EP-0410, 1991, Tank 241-A-105 Evaporation Estimate 1970 Through 1978, Westinghouse Hanford Company, Richland Washington

WHC-MR-0250, 1991, Waste Tank 241-A-105 Supporting Documentation, Miscellaneous Reports Letters Memoranda \& Data, Westinghouse Hanford Company, Richland Washington

WHC-MR-0264, 1991, Tank 241-A-105 Leak Assessment, Westinghouse Hanford Company, Richland, Washington

WHC-UO-88-029-TF-04, 1988, Unusual Occurrence Report Tank 241-AX-102 has Exceeded the 1.00 inch Decrease Criteria and Evaluations Cannot (with 95\% Confidence), Show the Decrease to be Due Solely to Evaporation, Westinghouse Hanford Company, Richland Washington

WHC-UO-89-023-TF-05, 1989, Unusual Occurrence Report - Surface Level Measurement Decrease in Single-Shell Tank 241-AX-102, Westinghouse Hanford Company, Richland Washington 
RPP-ENV-37956 Rev. 1

APPENDIX A MEETING SUMMARIES 
From: J. G. Field CH.M HILl. Hanlond Gmup, Inc

Phon: $\quad 376-3753$

Location: Ecology Ortice,

Dite: $\quad$ November 27, 2007

Subject: Tank Fam Leak Evquation

To: DistribulionAttendes s

Attender: Joe Caggiano, ECOLOCY

Jim Fieid CH2M HIL.L

1.'s Fort, ECOLOGYY

Paul He awaod, S.M Stoller

Mite Johnxon, CH2M HIIL

Marcus, Wood FLUOR

PURPOSE:

Axsers Tank 241-A-105 leak events

Revlew of Prevmus Mleting Summary:

The Novemher 6 , 2007 mee ting summary was revised per commens received fnom Ecology.

The levisions we re reviented and approved.

Rerlew of C-Fam Assesament Report

After the ctraft Hanford C-Farm Assessments Report (RPP-ENV-33418, Rev. 1) is rev ised to incorporate unplanned rele ases supple mental data and applicable mee ting summanes. the repon will be sent to Feology for review. This diflers from the original plan to re le use the drafl Rev. I previously sent to Ecology for eview with only the four tank leak assesme nts iC-101, C-110 C- III and C-105).

\section{Discumion of A- IOS Leat Eventa}

Marc Wood wirlsad through the conoeptual nodel prepared for the A/AX and C Farm Field Imestigation repon (FIR). The conoe ptual model and lank leak descriptions in the FIR will be referenoed in the ase esment reporn and not duplicaned Based on the conoeptual model presented an epproach to estimete a teak vatume and inventory wis discussed. Leak volume and imve ntory e stimates will be de veloped for discussion in the nex1 meeting Assumptions for the extimate ill include:

1. Assume labril gamma mens unements ane $\mathrm{Cs}-137$ contamination

2. Based on activity in the lekerds near the edge of the tank and based on where the bleel line $r$ is ripped along the ede of the tank, up to tis of the tank cincumfere noe could have le aled.

3. The le ak moves dow nward from the bankedge to the laterals in a trimgular distribution

4. The width of the contamination at the laterds is the ave rage measuled plume sine for activity detected along the laterals. 
5. The concentration of the entire plume fin mu tank to laterals is assumed to he at Cesium saluration caparity.

6. The s omposition of the tank leat was either B-Planl wiaste or PUREX , PI I uask leaked.

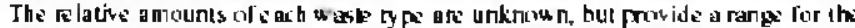
imentiory stimist:

\section{NFNT MEETING, AGEND.}

Conlinue to Assess Tenk 24 i-A-lion

2. Start A-IOit Assissment

ACTIONS:

1. J. Field: Prepare and distrihute Nowe mor 27, 2007 Dralit Mee ting Summery

2. M. Johnson: Prepare Drafl C.Farm Ass'ssment report iRey l i for revizu:

3. Johnson/Mark Wood: Prepare A-I liz Jiseussion for mexl meeting su marizing discussion in the C and A'AX FIR.

\section{NEXT MEETING:}

$\begin{array}{ll}\text { Date: } & \text { December 11, } 2007 \\ \text { Time: } & 3: 0 \text { is:30 } \\ \text { Lncation: } & \text { ECOLOOGY uflice }\end{array}$




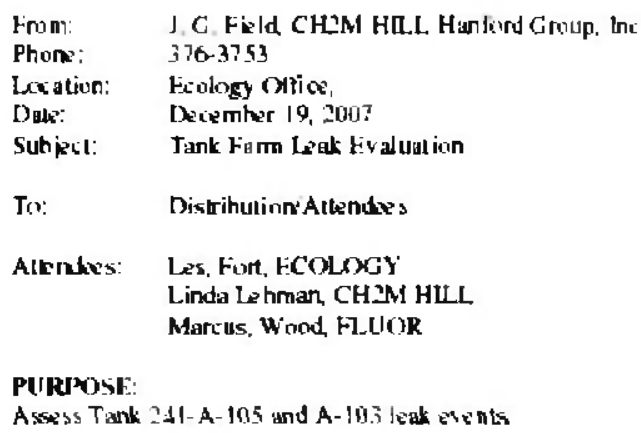

Dtacusion of A-10x Leak Information

Further discussion of tank A-los was lahkd hir the next meting when lim Field can ate fud.

Dkscussion of - 10. Leak Intormatkm

Marc Wicod discussed the A-103 malerials and his lindings Mare noted that A- loj was considered to be a sound Iank tor a very long lime. An earlier sludy investigated laterals and no coniaminalion was found exoept some minor hits were seen in the bend oukide the Tunk farm The laterals we re inuestigated aguin in 2005 and confirmed the lindings of the prey ious stady

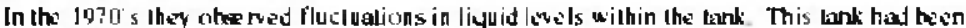
reviving ion ex change wastes from B Plant. II wis al so noted that the HC was rapidly

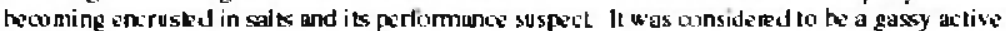

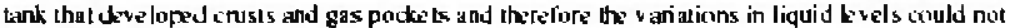
the detinitivily olated tor tank leaks.

Data from the late 1900 's reported gnoss gamma signuls at ahoul 75 feet below' ground surdace in Dry wells $10-03-07$ and $10-0,-01$ which surfound A- 10,3. These dry uells ane adjacent to lhe 
laterals and no signific anl 8 vide ne of contamination was found in lhe lalerals. The gross gamme measured in the in the dry wells in the |Porl's is assumed to be ruthenium bevause little

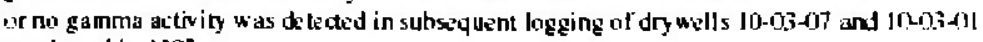
condured in 198 ?

It was vincluded that no v adose zone dry well or lateral measurements wene attributed to a

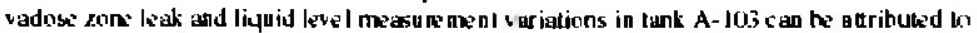
other causes, such as trapped $\checkmark$ apor releases in the waste and sall build-up on the FIC surtiace level gage. More detailed discussion of liepuid level decreases will be incluted in the assessment repris

The change in status from a sound tank wh an assumed leaker occurred in the 1980 's. A panel at experts was comvened to de mine whelher selected lanks were gound or were bakers. Their iharge was to have be ter than a g.5 contidence $k$ vel thel a lank was one or the other. The voli lor tank A-103 was 3 for Sound and 2 not sure to the 95\% contideme level. Because there was sime douht the tank integrity classilication was changed to to "essumed " laker. They assigned a bak volume of $5.5(x)$ gall ons, which was besed on the uncertainty in the FIC liquid level in? asure ments.

Jhe assessment tam members present onndided thal husu on the gy ailable intormalion, there is me videno that tank A- 103 lost contuinment and no leak v ol ume of imve ulory uas assigned for this t:ank:

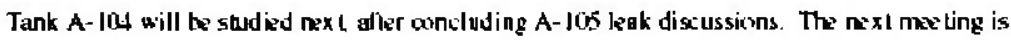
sctoduled for January $8,2008$.

NFXT MIETING, SGENDA

I. Continue bi Assess Tank 241-A-lob

2. Starl A-IIUL Assessmint

\section{ICTIONS:}

I. J. Fixid: Prepare and distribute Deoe nher 8, 20u? Draft Meeting Summary.

2. M. Johnson: Prepere Drall C.Farm Assessment report i Ren. I i for rew iew.

3. 1. Field: Send Foology the kak assessment proess re pron RPP-32681

\section{NFITT MEETING:}

\begin{tabular}{ll}
\hline Dake: & Decomber I1, 2007 \\
Time: & $3 .(0) 4: 30$ \\
levalion: & FCOLOOGY tofice
\end{tabular}


From: J. G. Field CH2M HILL Hunlord Group, In

Phen:: $\quad 376-3753$

Lection: Fookgy Otrice.

Dale: $\quad$ January 8,2008

Subjel: $\quad$ Tank Farm Leak Fualuation

Tn: Distrihution Attendes s

Altrindes: Joe Caggiano, FCOL.ugy

Les Fon, FCOLOGY

Jim Field CH2M HILL

Linda Le hmian CH2M HLL

Beth, Rachedtr, ECOLIGG'

Marcus, Wood FI.UIOR

PLIRPOSE:

Review Tank A- 103 A ssessment and Discuss Tank 241 -A-105 krak wolunk calkulations.

Resku of Pres bous Meeling Summary:

The Droemher 19. 2008 meetine sumnary was reviewed and thanges we le identilied. Previous discussions and assessmenls tor bank A-IOJ were clavitied. The changes will be made and the

Decomber Il mesting summary redistrihuled for row iew'

Res lew of C-Farm Ascessment Report

CHIM HIL provided a disk to KCOLOGY' wi niview the C Farm leak loss assessment report 1 RPP-F_NV-33418. Rev. I and requested comments by the end of January. It was noled that this rev ision does not change the wribe- up or candelusions ne vir ued previousty for C-101, C-1 10. CIII and C-II) 5 assessments. The primary change is the addition of Unplanned Reletuses I UPRs, and other porrolial me leases ase ssed.

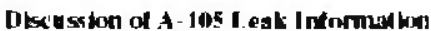

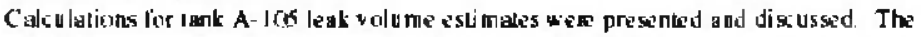
calculations ure hesed on assumptions droumented in the Now mhe 27 mes ling. Based on

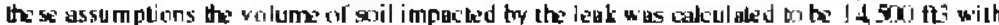

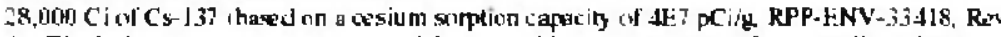

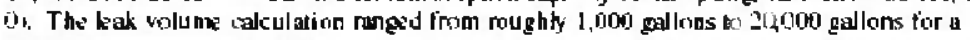
PLIREX supernatant iCs- 137 onnerntration $=30.7$ Cigal and for a B-PI unt w aste concentration - I 38 Crgal r respecively. Baced on lateral gamma oneasurements the contamingtion appars to the a combingtion of the two werate ty pes, but the relative contribution at eas is unknown. Any dilution of the waste would further increose the estimalied leak volume. Howe ver, neither the waste ty pe or dilution thange the estimated Cs-1.3? Cicontent 
Alter reviewing the cal culalion participants apred that the volume of sovil impacted could have ben larger than thal assurixd for a triangular distribution of waste finm the base of the tank to

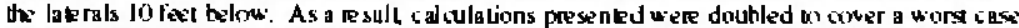
assuming uaste sperad at the base ol the tank as much as it did at ibe latenals ie. acylindrical distribution inim the tank ।. This results in a Ci content for the leuk of 56,000 Ci wilh volumes ranging from toughly $2000 \mathrm{gal}$ lor $10,000 \mathrm{~g}$ gallons. Detailed calculations and figures will be fresented in the assessment report.

Future Ascestaments

Tank A-104 will be studied nex I menting scbeduled for fen uary 22, 20ue.

Participants the discussed a potemial shitt in the Tenk Fam leak asessments from focusing on lank larm closure neds lo focusing on ce nutal plale au v adose and ground w aler priorities

ide nutied by the groundwater inte gration project team i IPT. All were supportive ol this shith in tous. Prioritized gnoundwate r meds are scheduled on be discussed January 2,3 in IPT mee lings.

\section{NEXT MEETING, AGENDA}

I. A-104 Assessment

\section{AC TIONS:}

I. J. Field: Prepare and distrihute January 8, 2008 Drafl Maxting Summary.

2. All: rev is u. C-Farm Assessment report iRev. 1 i.

3. M. Wond: prepare A-IOL disussion tor next meting

\section{NENT MEETING:}

Date: Januery 2.;, 2008

Tine: $\quad$ i:00-4:-20

Leation ECOLOGY Oflice 
From: J.G. Feld CH.M HILL Hanlord Group, in

Phon: $\quad 376-3753$

lukation: Fcology Mrice.

Dake: January 20. 2008

Suhiect: Tank Farm Leak Fvaluarion

I(1) DistribulionAllendes

Altentes: Jow Cangiano, ECOLGCY

1.s Fon, ECOLOCY

Jim Field, CH?M HCLL.

Paul Henwod. STOLL.ER

Beth, Rochelte. FCOLOGY

Marcus. Wond FLUOR

PURPOSE:

Review. Tank A- luid leak liks:

Rev lew of Pres hous Necling Sammary:

The December 19. 2007? and Januery 8, 2008 mexting summeries we en reviewed and approved

Discussion of A - INW Lesk Infinmution

Tho A-104 tank ore mating history and waste types and lateral and drywell logging results were discussed. This information will the included in the assesmenl report. Tank A-jou was declased an assumed kaker besid on an increase in radiox tivity okerved in lakeral I during sluicing in April 1075. Lateral data ohtained from 1977 to 1001 show eley a ed ganma activity hok the lank thot indicates the presence of a tank kat. The level col radionctin ity measured at the laleral ie250 counts per second indicales that the leak was small. No ele valed actry ity was ohserved in

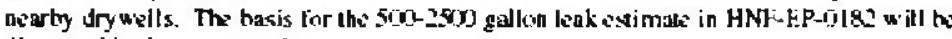
discussed in the next mov ting

\section{NEXT MEETING, AGENDA}

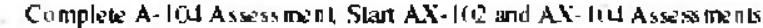

ACTIONS:

I. J. Fis:ld: Prepare and distrihule January 29,20 , Drat Mexting Summary.

2. M. Johnson: Reyiew hesis for A-ICu leak volume estimate

3. M. Johnson: Prepare AX-IOC and AX-104 intormation bo discuss

NEXT MEETING:

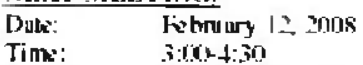

Luation: FCOLOCY Uflice 
From: J.G. Find CH.M HILL Hankond Group, Inc

Phon: $\quad 376-3753$

Luntion: Ficology Oflice.

Dale: $\quad$ kebruary 19. 2008

Subjecl: Jank Fam leak Fivaluation

To: DistrihutioniAttende:

Distribution: Jow Caggiend, ECOLuCY

Les Fort, ECUL,UGY

lim Field CH2M HILL

Paul Henurod, STOLLER iAtendes

Michal F. Johnsols IAllendeel

Beth Rochelle, ECOL.UGY

Mancus, Wood FLUOR

PURPOSE

Review. Tank A-104 leak volume stimat.

Revisu kadkgound information for historical leaks from Tanks AX-162 and AX-104.

Review of Pres bous Mleeting Semmary:

The January 29, 2008 meting summery was reviewad and approwed withut changes.

Deacusion of A- IN Leak Vintume listmate

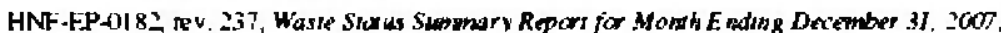
extimates theture in 500 to 2500 galions of wate was loss from SST A-104 in 1978 . The bas is lor this eslimale is ciled as PNL-4688. Assessmery of Single-Shall Tank Resudual Lequid dssues. Section 3. I.3. I of PNL-4688 discusses past leaks linom SSTs as of May 1982 and provides a

lahle summarizing estimatrd leak w olume by each tank. PNL-4088 refete noces RHO-RF-SR-14May 198? Waste Sa is Stemmany May 1982, as the source identifying kaking SSTs and states the estimated wast kaked from SST A- 104 is 2500 gallons. RHO-RE-SR-I4-May 1982 ide ntilies SSTs thet were salegorixed as having kaked w'at, hut does NOT list the volu me of waste leated Irom any of these SSTS. PNL-4688 provides no olher bas is for the stimated waste lass from SST A-104.

The first time estimate s for waste losses from SSTs appear in a monthly waste starus sutumary report is in Septe nber 1983 iRHO-RH-SR-14 - September 1983, page 28. The reported estimaled waste loss from SST A- I04 is less than $1,500 \mathrm{~g}$ alons. The estimated waste loss from SST A - 104 reported in RHO-RE-SR-1:4 - September 1983 is consistenl with the estimated waste loss of 700 bo 1,500 gallons reported in July 1975 by the Hanford site contractor in

correspondenoe with the LI.S. Fnengy Resanch and Developmenl Adminisaralion iBurton. 19751. Furthe more, the tank farm contracour's monthly report for June 1975 also ne ports lhe estimated wasle laes from SST A-104 as 700 to 1,500 gedlons i ARH-LD-20k B, page 10!. 
None of the identified re le rence documents provite an actual busis for the exlimated waste loss Irom SST A-IOH. The tram recommended that the nelerence lor the estimated waste loss from SST A-104 be cied as Burton 1975 in ruture revision of HNF $1:$ P-10182 and the eslimaled waste loss wolutar to changed to ? 700 bo 1,500 gallons

Dtacusion of Tank AX-192 Leak Loss

A summary of Tank AX-102 design leatures operulional history, and histarioal balk loss in longation thal w'as Jistributed w team me mhers prior to this mexting was review ad and Jiscussud.

Atrentes discussed the balkage of wondensale thal was avolved finm Tank AX-102 through an undergrou nd vapor te adef as well. Condensate keakge from the untergmund uapor heder was deteced in drywell I I-02- I 1 when tïrst monitored on Februery II, 1975. Auger drilling conducted arrund this vapor header in 1975 logd to the discovery thal compression seals 1 is. Dresse r couplingsion the vapor beader we le lek ing A new drywell I I-02-12 inslalled in May 1975 contimed the condensale kakng from this sapor header. No historical egtimate was

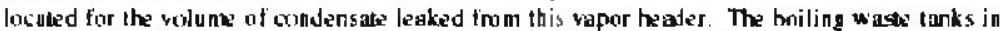
the $241-\mathrm{Ax}$ and $24 \mathrm{~J}-\mathrm{A}$ lank farms whe connected to this heder and material halance inliumbrion is inadequate to determin: vapor header losses.

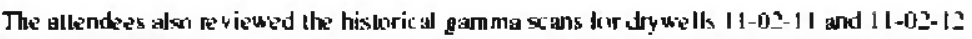
Itom RPP-88:1. Th:se scans show gness gamme radialion detected in tryuells I 1-02-11 and $1102-12$ were cortel ated to rulhenium-106 dec 1 rals for radioativity delected at $50-60$-ft has in tryuell $11-02-11$ and 32-54-1t hgs in dryusell $11-02-12$. Th: hislonical gmos gamma radiation

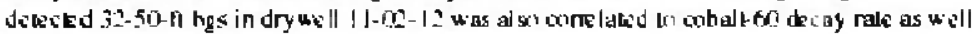

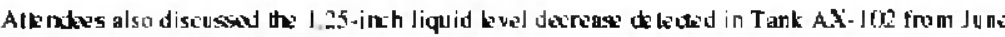
18, 198 through May 2?, 1988 . This linu id level decrease is lhe basis thr the estimaled wasto loss of -3,00ugallons finom Tank AX-102.

Dbcussion of Tank AX-104 Leak Lass

A summary of Tank AX- lod design lealures nperolional history, and historical kak loss intonmarion that $u$ as distributed wi team ax mhers prior to this meting was review'ad and discussed. A graphical limeline for Tank AX-104 events u as al son presented.

As with Tenk AX-IOZ, the Dresser coupling joining the Tank AX-106 exhaust pipe to the uderground vapor he ade $\mathrm{w}$ w found to be leak ing condensale in 1975 . No historical estimale w as located for the colume of condensate leaked from th is vapor header. The boiling w'asse ank sin the 24 l-AX and 24l-A tank tarms a'ere connected to this header and malerial balance intonmerion is inadequat: to debrmine v apor header losses.

Tank AX-101 wasclass ified as questionable inlegrity and remoyed finm active service in August 1978 as a result of the radicaclivity delected in drytell II-04-198. However, the soure at the

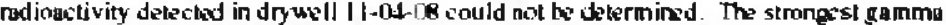
radition signed was detected tue east, tow and tank AX-104, which led personnel in 1978 ko suspel the incegrity of the tank. No corresponding liapu id level decline or e lev abed radiation 
readings were delected in the leak detection pit al the lime increased radicectivity was detected in dryuell $11-04-0$. The estimaned wiase loss of 8,000 -gallons for tank AX-104 is based solely on the averuge waste loss Inom 18 ather SSTs for which liquid level decline was reported.

The attendes discussed that a conoeplual model meds to be developed that would axcount for

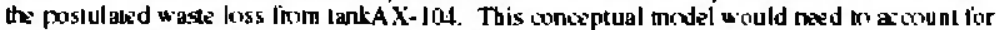
radiogclivity detected in dryw II I 1-04-0.8 without corresponding activity toing tetected in the bo ak dekeclion pil associaked with tank AX-104.

\section{NEXT MEFTING, AGENDA}

1. Complete AX-102 and AX-104 Ase ssments

\section{ACTIONS:}

1. M. Johnson: Prepare and distrihule Kehruary 10, zock Drafi Meeting Sumnary.

3. M. Johnson: Present hiskrical gamma analyses for drywells surmunding Tank A X-104 at next meeting.

3. M. Johoson: Prepare AX-102 timeline.

4. P. Henwood: Provide felerence infonmation fur precis ion and detection capobility for probes used to scan drywells.

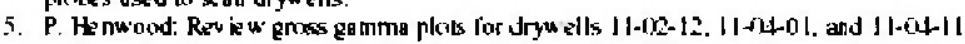
on deverming if correction of the data is meded hased an diflerent probes used to scan Jrywiells.

\section{NEST MEETING:}

\begin{tabular}{|c|c|}
\hline & $\begin{array}{l}\text { March 4. } 2008 \\
3 .(0)-4: 20\end{array}$ \\
\hline & $\mathrm{ECOl}$ \\
\hline
\end{tabular}

\section{References:}

ARH-LD-206 日. 1975, Aslannc Richield Hanford Companv Monshy Repory Juke 1975. Adlantic Richliald Hanford Company, Richland Washinglon

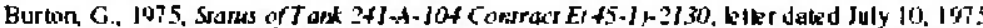
Irom G. Burton Vice Pre sidenl Produclion and Waste Management Atlantic Richtie ld

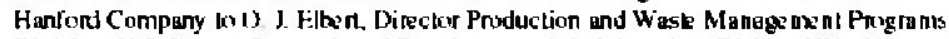
Division. UIS. Energ Resegrch and Devekpanent Administruion, Richlend Washington

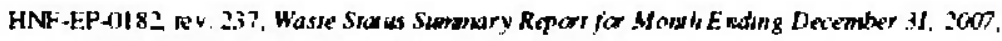
CH2M HLL. Hanford Group lnc., Richl and Washington

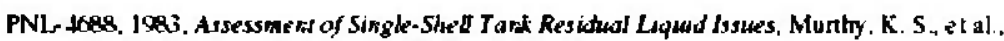
Pacitic Nortrwest Lubortory, Richland, Wushington 


\section{RPP-ENV-37956 Rev. 1}

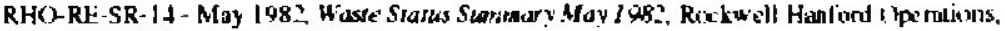
Richland Washington

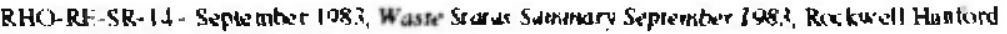
Opentions Rich!nd Washington 
RPP-ENV-37956 Rev. 1

From. J. G. Feld CHבM HILL Henlord Group, inc

Phon: $\quad .376-3753$

Lousion: Fiology Ortice.

Dote: March 4,2008

Subjzct: Tank Farm leak Fvaluation

To: DistributioniAtkendes

Distribution: Joe Caggiano, HCOLUCY

Jim Field, CHבM HLLL

Paul Henuond, STOLLER

Michazl E. Johnson

Beth Rochelle, ECOLDGY

Marcus, Wood FLUdoR

PITRPOSE:

Complete AX- JO2 and AX-104 assessmenls.

Rev lews of Prev bavs Mkeling Sunumary:

The lebruary 19. 2008 meeting summary was reviewed and approved. Inlommatiun requested by Ficology will te included in the essessment report.

Assigned actions wete oompleted. Paul Hembood verified that the g toss gamma data for

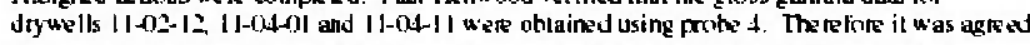
that onfection of the dela is not needed. The assessmem repont w-jll slarily which proter was used to ohtain the dala.

The assessmenl team was inlonmed that the C.Farm assessment mporl I RPP-3.3141, Rev. I , w'as issued and posted to a CH2M HLLLe xtemat web page.

Dreassion of AX- INM Leak V du rem Extimate

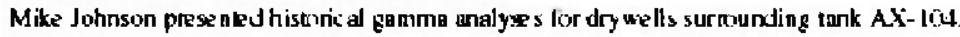
$\mathrm{No}, \mathrm{Cs}-1.37$ was discovered in the dry wells around AX-1040 AX-100.

Dresser couplings prov id a compression seal on the outer surlace of vapor header pipe segments in the 211-Ax and 24l-A lank farms. The couplings provid line expansion and contraction of the vapor heacer pipe segments i Ser Figure Ji. The leam concluded that waste losses from Jresser couplings were a probab be cause of ne asured gem me in drywells and a kak from the lank was unlikely. No liquid level decreases we re observed in Tank AX-Jo4. Other contamination in nearby drywells and radicaclivity surface data will he discused in the next mecting. 
Higure 1. Typical Dresser Coupling arrangement

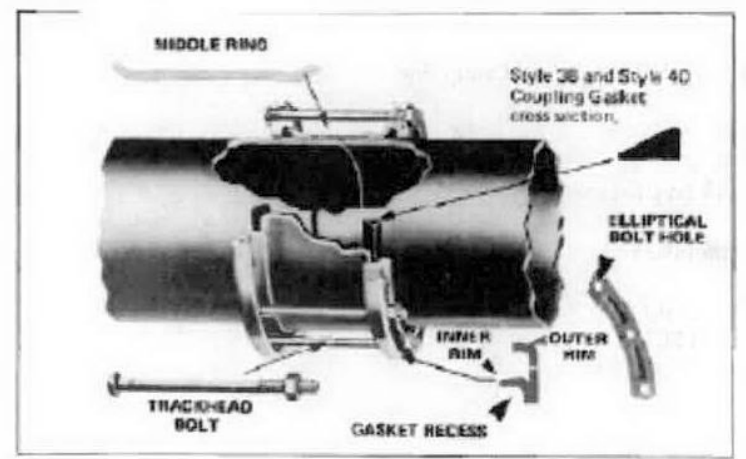

Dtscusson of AX-102 Leak Violume Extimate

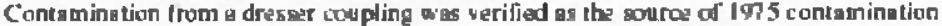

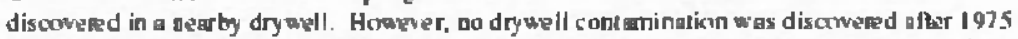
or ne the time of liquid lovel decreases. Liquid level decreases ect ating to 3 t 40 gallons do not

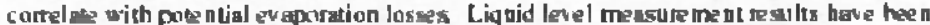
questioned because of a huidup of corrosionts um an the instrument probe. How ever, there is insufficient eviclence to verity the instru ment was bad. It was further aberved that $A X-102$ is

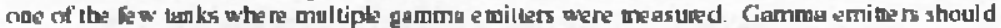

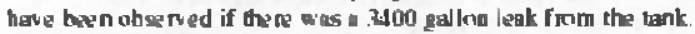

The pang / concluded that thee is aflicient evidence to quation a tank leak and no basis lor assigning a leak kes valume or imentory for this tauk.

\section{NEXT MEETING AGENDA}

1. Complete AX-IOS Assessments and begin UPR assesmments In prepafution for aext meeting $M$. khnson distributed a hendwut summarizing LPRs in he A and AX Fomis.

ACTIONS:

1. J. Fiald Pepare and distribute March 4. 2008 Draft Blating Summary.

2. P. Hemood: Roviow drywell data in $\mathbf{A}$ and $\mathbf{A} X$ larm

3. M. Jnhoson' Look up information for entfoce ndinactivity measurements in the farms

\section{NFIT MEETING:}

\begin{tabular}{ll}
\hline Dale: & April 1. 2008 \\
Time: & 3:C0-4:30 \\
Locution: & ECOLOGY Office rom 3B
\end{tabular}


RPP-ENV-37956 Rev. 1

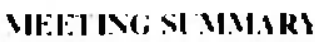

CH2MHILL

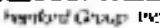

From: J. G. Fisld, CH2M HII,L Hankind Group, In

Phone: $\quad 376-3 ? 53$

Lecation: Ecology Orfice.

Dille: April I, 2008

Subject: Tank Fam Lrak Fvaluarion

To: Distribution'Attendes

Distribution: Ite Caggiano, ECOLOGY

Jim Field, CH2M HILL

Les find FCOLOGY

Paul Henaond, S. M. STOLL.ER

Michag I Johnson, CHבM HILL.

Marcus Wiond, HLLOR

PURPOSE:

Complew Ax-104 Assessment and assess other meleases in the A- and Ax-Fam.

Rerbw of Prev kus Mketing Summary:

The March 4, 2008 mexting summary was revieued. A rypo was observed and a request to

detine "dresser coupling." Chenges to the summary will he incorporaled and the tinal summary distribuled

Contunued Discusskn of AX. 104 Le ak Volume Estintse

It was noted that the gamma acuivity in dry well 11-04-08 sarted to increase during sluicing of lark AX-104. Sreral possibilities tot the gamma activity uere discussed. The gamma signature is not consistent with a bank $k$ uk. The nnly indication of a possible bank kak is the continued increse on gamma activity in $11-0408$ duning the previous sluicing campeign.

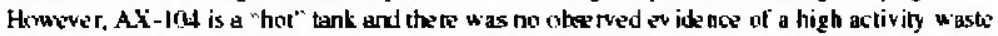
type in the soil. Parlicipants would not conclude whether tank AX-104 lost invegrity. Howener, because the tank has alrendy bee n sluiced and temaining te siduals afe "hot," participents believed that A X-IOL is nol a likely candidat for sluic ing regardless of we hether it has lost integrity

Uoplenened Releases

A lisl summarizing unplanned re kases in 24t-AX was prepard and discussed.

UPR's included in the Weate lntormution Dato System rWLS , include the following

UPRs-F-18 and E-42 are outside the fam and are identilied in WIDS as "cleaned up" sites.

Chan up crite na and slandands are nol specilied.

Nole: UPR F-115 and UPR-E-119 were intrchanged on the C-Farin and A Complex Drawing

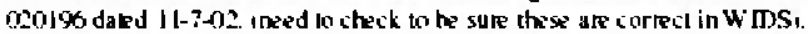




\section{RPP-ENV-37956 Rev. 1}

UPR-F:- $1+5$ is far outside the farms ido not include in assessment - SDM i assu mes a P3 waste type lor this release. It was notid ther the waske is likely cinnde nsate in a vitrilied clasy pire.

UPR s-F-47, 18. 115 and 110 are identifind in WIDS as particulate or small releases No imenkory orol the detemined

Surlace Radioativity surveys from Feb. MOXt , the unost currant in IDAS , do not show high activity between the lanks; only known activity is over the lanks at riser pit locations. Be Iuten the tanks a ION cpm ins ar baik ground was measured

Tao locations not cumenlly identified as UPRs wer identified in 241-AX lam and discussed. These were:

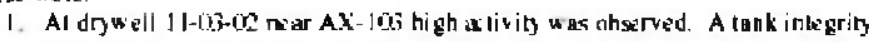
aswsment con-luded Ax-103 was not the sounx. The sounce of this alivity is likely a

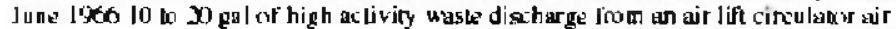

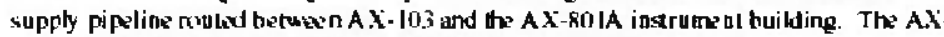
801 A insurument truilding was decontaminated intermithenly oves a thre week priow using water and chemic al isodi uny hy dox ide, citric acid oxalic acid tartarit acid. tri-scidium phrisphake, and polassium remanganate i flushing. Thess tlush soluticns we $\mathrm{ke}$ initidly discharged to open Ine nohes iquanlity not specilindi dug outside the huilding.

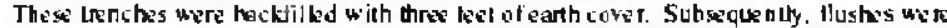
meved to tur cribs al the north edge ol the $24 \mathrm{~J}$-Ax form. Following these flushes, lead

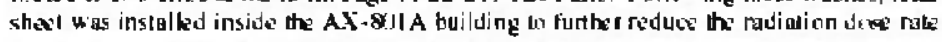
- ISO-416 PTI page 4i. Norecord was loceled that details the volume of the Hush vilutions used.

2. A pipeline fiailure near AX-103 where Cs-1,37 was ubserved al $25 \mathrm{n}$ hes. This is atlrihulad to a pipline bak hetwen AX-102 and the JonC pump pil Liquid was ohererved orming from the gonund near the Ax-103 pump pit on 1-212-68 during atempts to unplug the Ax-lon to C-lor? line u ith hol water.

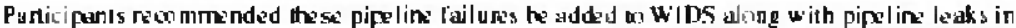
C-Furm that are not yel identified as LIPRs

No tank onetlow 5 are indicated tor boiling waske banks in A and AX Farm. More chtailed descriptions and rele re nces for these LIPRs and iatormation presented during the meting will he included in the A-AX Assessment report.

Idditiond Discustions:

C-Fam imentory Jiscussions in Tank Farm Vadese Zone Coniamination Volu me Eslimales

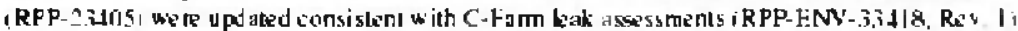
A dratl new ision was distrithuted for Fon log ac u i w

NFIT MEETING, AGENDA

Bagin SX-Fiarm assessments 


\section{RPP-ENV-37956 Rev. 1}

\section{IC TIONS:}

1. J. Field: Prepare and distribute Annil I. 2008 Draft Blesling Summary.

2. M. Johnson: Prepare SX-Fam information for diseussion.

i. M. Johnson: Prepase A-AX Farm Asessment Report.

\section{NEXT MEETING:}

\begin{tabular}{ll}
\hline Date: & April 15, 2008 \\
Tim: & i:104:30 \\
Loxation: & FCOLOGY uffioe room .iB
\end{tabular}




\begin{tabular}{|c|c|}
\hline $\begin{array}{l}\text { From. } \\
\text { Phon: }\end{array}$ & $\begin{array}{l}\text { 1. G. Field CH.M HIL.L. Hankind Group, lnc } \\
376-3753\end{array}$ \\
\hline $\begin{array}{l}\text { Loxation: } \\
\text { Date: }\end{array}$ & $\begin{array}{l}\text { Foulogy Ollioe, } \\
\text { April } 15,2008\end{array}$ \\
\hline Suhjicl: & Tank Fam Laak Fualuation \\
\hline Tr: & Distribution'Attendes's \\
\hline Distrihution: & 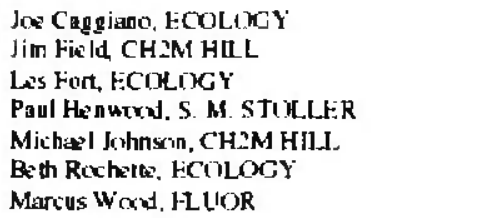 \\
\hline
\end{tabular}

Revilew on Prei wous Neating Summary:

The April J, 2008 mevting summary wis revizwed and approwed with changes

Additions Disctiaston of A/AX -Farm ITPRs

Himphasis was added thal the inve ntrry for UPRs in AiAX -Fam aruld nol be de temined.

Although some UPRs are listed as "clemed up" in WIDS. The crite ria for consickring the sites

cleaved up at the time are unknown, as is the detection limit for uny instruments used to make

this judgment Typically in the pesl siles uere cleanede mughto eliminat smaraht

contamination and to allow workers in to the location.

\section{Assegsenent of $5 x-114$}

Informalion reganding kank translen, eperating ou nditions and ountamination chservad ne ar SX-

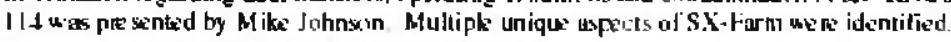

Presentation details witl he in the ussessment pert.

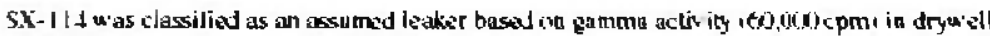

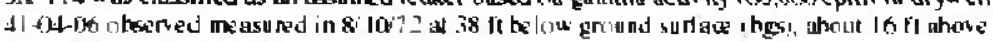

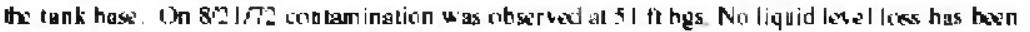
otserved and no le ak intentory assigned in the pest. However, thene are no kmoun pipeline leaks

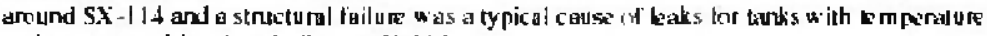
and waste type hiswories similar to Sx-II4.

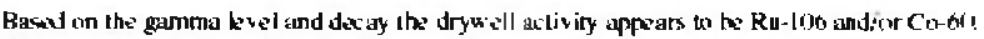

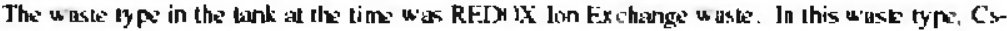


RPP-ENV-37956 Rev. 1

137 w'as extracted from REDOX high tevel waste. An action was wrigned to look closer at the records to dearmine the percos of of Cs extracked in the process and the ratio of Cs to Ru waste following extration. This may enable a rough calculation 10 estimale on upper hrund leak ime ntory. Lacking that, no leak volume extianale could be determined.

Becauge no Cs was obsened and Ru 106 has decoryed. lutare dharncteriz ation ne ar drywell 4 las-06 wonld target chemical constiluents. This leak appears lo be minor compered to other SXFarm reletseg and additional characterization may not be wamanted.

\section{NEXT MEETING AGENDA}

Continge SX-Farm leak assessments ( $\mathrm{SX}-113$ and 115 )

ACTIONS:

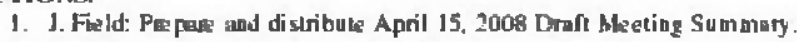

2. M. Johnson: Look for information show ing the $C_{5}-137$ onnomiration after the $C_{5}$ extraction prooss and the Cs/Ru natio for the wask.

ifinding: The HDW kev. 5 Mode I does not conlain a sepanab de lined waste lype for REDOX jon ex chunge wast and no ample analy ses of this wiasle type mene loc aned. There fure an estingate of the w'este loss inven nory an not be made at this time u king the Ru-106 conos ntrution and assutred laak genmetry. 1

3. M. Johnoon: Prepare additional SX-Farn informution for discussinn

\section{NEST MEETING:}

Dela: $\quad$ April 29, 2008

Tim: $\quad 3: 00-4: 30$

Lacation: ECOLOGY Office reom 3B 